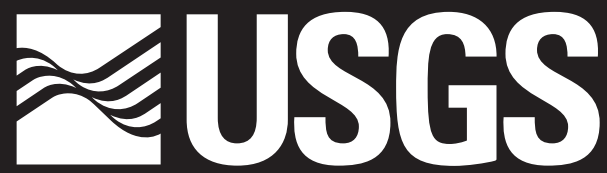

science for a changing world

Prepared in cooperation with the

MASSACHUSETTS EXECUTIVE OFFICE OF ENVIRONMENTAL AFFAIRS and the

MASSACHUSETTS DEPARTMENT OF ENVIRONMENTAL PROTECTION

\title{
A Logistic Regression Equation for Estimating the Probability of a Stream Flowing Perennially in Massachusetts
}

Water-Resources Investigations Report 02-4043
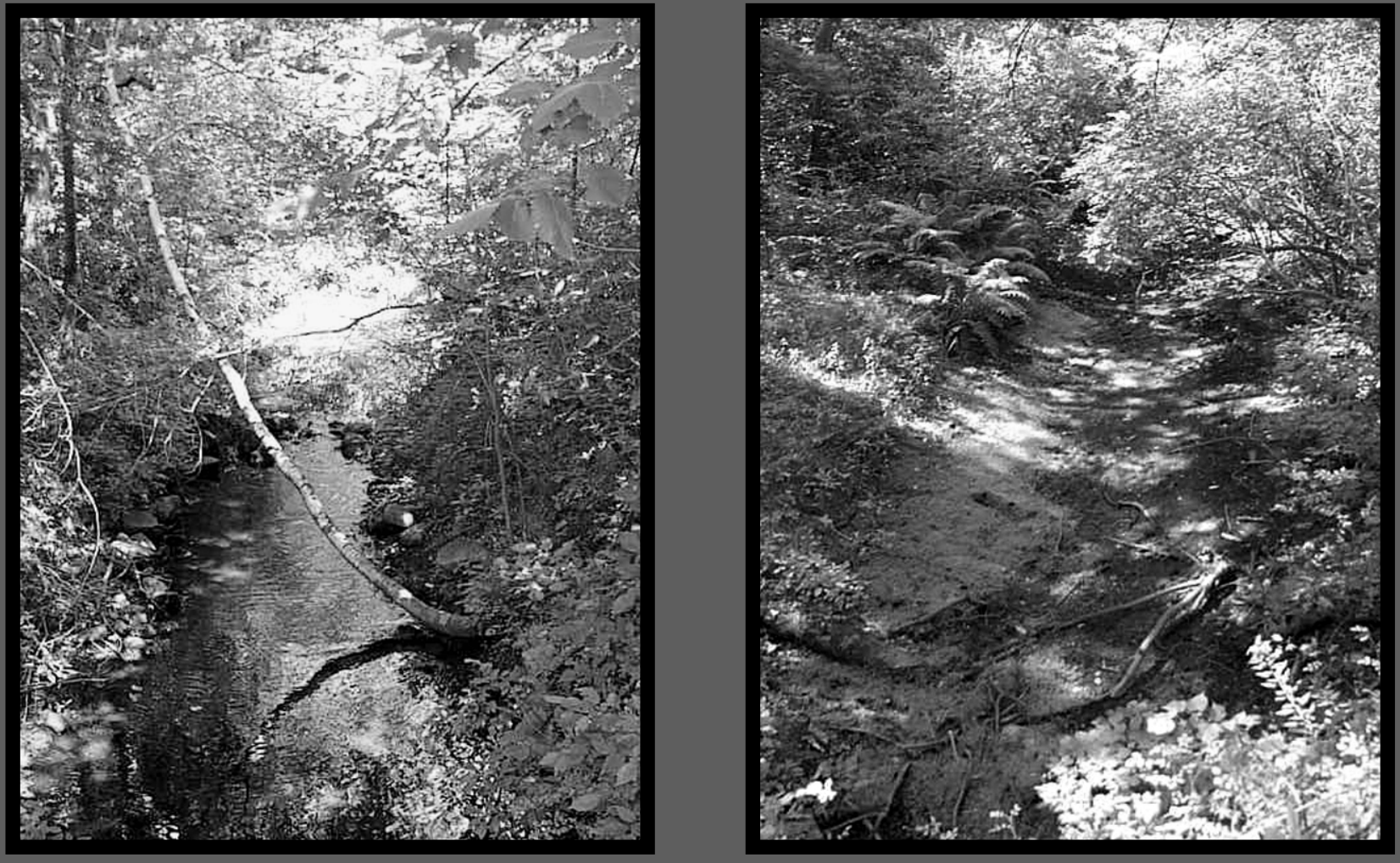

U.S. Department of the Interior

U.S. Geological Survey 
Cover photographs are Shinglemill Brook, Hanover, Mass. (station HR-61) (left) and Unnamed Tributary to Bluefish

River, Duxbury, Mass. (station DY-53) (right). 
U.S. Department of the Interior

U.S. Geological Survey

\section{A Logistic Regression Equation for Estimating the Probability of a Stream Flowing Perennially in Massachusetts}

By GARDNER C. BENT and STACEY A. ARCHFIELD

Water-Resources Investigations Report 02-4043

Prepared in cooperation with the

MASSACHUSETTS EXECUTIVE OFFICE OF ENVIRONMENTAL AFFAIRS, and the MASSACHUSETTS DEPARTMENT OF ENVIRONMENTAL PROTECTION

Northborough, Massachusetts

2002 


\section{U.S. DEPARTMENT OF THE INTERIOR \\ GALE A. NORTON, Secretary}

U.S. GEOLOGICAL SURVEY

Charles G. Groat, Director

The use of trade or product names in this report is for identification purposes only and does not constitute endorsement by the U.S. Government.

For additional information write to:

Chief, Massachusetts-Rhode Island District

U.S. Geological Survey

Water Resources Discipline

10 Bearfoot Road

Northborough, MA 01532

or visit our Web site at

http://ma.water.usgs.gov
Copies of this report can be purchased from:

U.S. Geological Survey

Information Services

Box 25286

Denver, CO 80225-0286 


\section{CONTENTS}

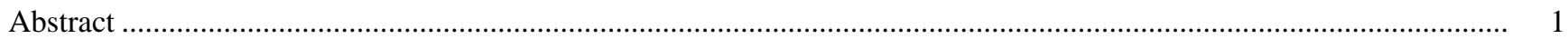

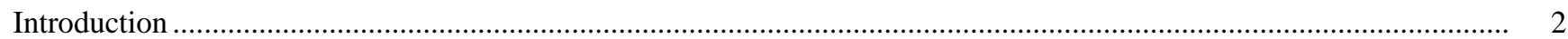

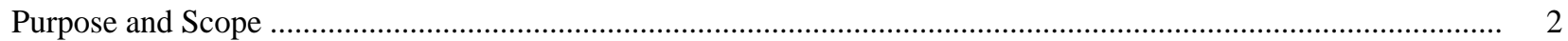

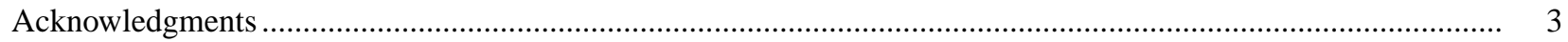

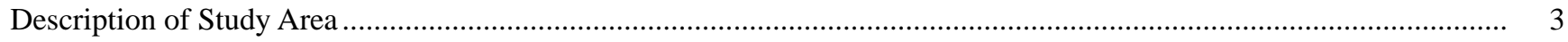

Characteristics of Massachusetts.................................................................................................................

Characteristics of South Coastal Basin .........................................................................................................

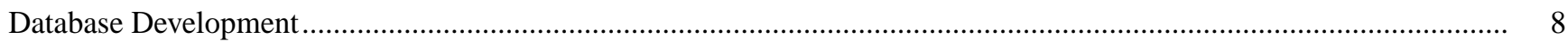

Factors that Affect the Perennial/Intermittent Status of Streams ...................................................................... 8

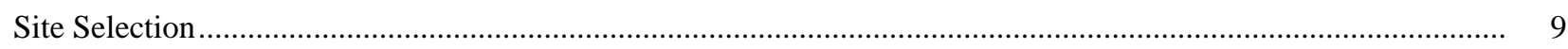

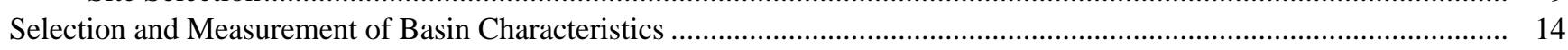

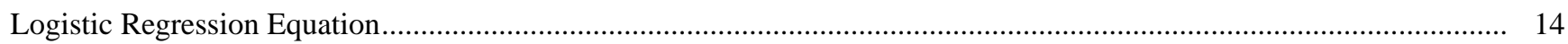

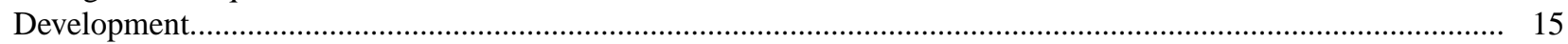

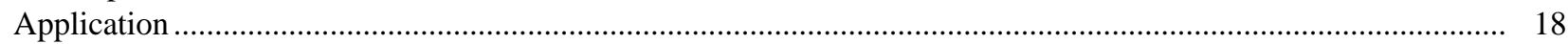

Limitations of the Logistic Regression Equation and Areas for Further Study ........................................................ 20

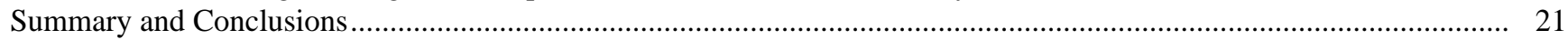

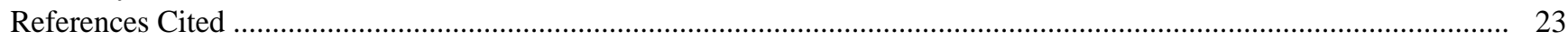

Appendix A. Summary statistics for selected logistic regression analyses tested for use in development of an equation for estimating the probability of a stream flowing perennially in Massachusetts ................................. 45

\section{FIGURES}

1-3. Maps showing:

1. Location of discontinued and continuous streamflow-gaging stations and partial-record stations designated as perennial or intermittent stream sites used in development of the logistic regression equation for estimating the probability of a stream flowing perennially in Massachusetts

2. Location of field visited stream sites in the South Coastal Basin, southeastern Massachusetts, designated as perennial or intermittent stream sites used in development of the logistic regression equation for estimating the probability of a stream flowing perennially in Massachusetts ......

3. Location of precipitation stations analyzed to determine if the eastern region or western region of Massachusetts met the 310 Code of Massachusetts Regulations (CMR) 10.58(2)(a) definition of extended drought.

4. Boxplots showing distribution of $(A)$ drainage area, $(B)$ drainage density, $(C)$ areal percentage of stratified-drift deposits, and $(D)$ mean basin slope for intermittent- and perennial- stream sites in the eastern region (ER), western region (WR), and South Coastal Basin (SCB) of Massachusetts used in development of the logistic regression equation for estimating the probability of a stream flowing perennially in Massachusetts

5, 6. Graphs showing:

5. Observed frequency of perennial-stream sites by drainage-area range in the $(A)$ eastern region,

$(B)$ western region, and $(C)$ South Coastal Basin of Massachusetts

6. Total monthly precipitation from January through September 1999, as a percentage of the average long-term monthly precipitation for 1960-99 at the Brockton, Falmouth, Middleborough, and New Bedford precipitation stations near the South Coastal Basin, southeastern Massachusetts. 


\section{TABLES}

1. Months that the eastern or western regions of Massachusetts met the 310 Code of Massachusetts

Regulations (CMR) 10.58(2)(a) definition of extended drought from January 1960 through August 1999

2. Analysis of maximum likelihood estimates for the logistic regression equation for estimating the probability of a stream flowing perennially in Massachusetts

3. Classification table for the logistic regression equation for estimating the probability of a stream flowing perennially in Massachusetts

4. Description, basin characteristics, and perennial- or intermittent-status determination for stream sites at discontinued and continuous streamflow-gaging stations and partial-record stations by region and major river basin in Massachusetts used in development of the logistic regression equation for estimating the probability of a stream flowing perennially in Massachusetts.....

5. Description, basin characteristics, and perennial- or intermittent-status determination for field-visited stream sites by town in the South Coastal Basin, southeastern Massachusetts used in development of the logistic regression equation for estimating the probability of a stream flowing perennially in Massachusetts

\section{CONVERSION FACTORS AND VERTICAL DATUM}

CONVERSION FACTORS

\begin{tabular}{rcl}
\hline Multiply & By & To obtain \\
\hline foot & 0.3048 & meter \\
inch (in) & 25.4 & millimeter \\
mile $(\mathrm{mi})$ & 1.609 & kilometer \\
square mile $\left(\mathrm{mi}^{2}\right)$ & 12.590 & square kilometers \\
& Temperature in degrees Celsius $\left({ }^{\circ} \mathrm{C}\right)$ can be converted to \\
& degrees Fahrenheit $\left({ }^{\circ} \mathrm{F}\right)$ as follows: \\
& ${ }^{\circ} \mathrm{F}=1.8^{\circ} \mathrm{C}+32$ & \\
\hline
\end{tabular}

VERTICAL DATUM

Sea Level: In this report "sea level" refers to the National Geodetic Vertical Datum of 1929 (NGVD of 1929) - a geodetic datum derived from a general adjustment of the first-order level nets of the United States and Canada, formerly called Sea Level Datum of 1929. 


\title{
A Logistic Regression Equation for Estimating the Probability of a Stream Flowing Perennially in Massachusetts
}

\author{
By GARDNER C. BENT and STACEY A. ARCHFIELD
}

\section{Abstract}

A logistic regression equation was developed for estimating the probability of a stream flowing perennially at a specific site in Massachusetts. The equation provides city and town conservation commissions and the Massachusetts Department of Environmental Protection with an additional method for assessing whether streams are perennial or intermittent at a specific site in Massachusetts. This information is needed to assist these environmental agencies, who administer the Commonwealth of Massachusetts Rivers Protection Act of 1996, which establishes a 200-foot-wide protected riverfront area extending along the length of each side of the stream from the mean annual high-water line along each side of perennial streams, with exceptions in some urban areas. The equation was developed by relating the verified perennial or intermittent status of a stream site to selected basin characteristics of naturally flowing streams (no regulation by dams, surface-water withdrawals, ground-water withdrawals, diversion, waste-water discharge, and so forth) in Massachusetts. Stream sites used in the analysis were identified as perennial or intermittent on the basis of review of measured streamflow at sites throughout Massachusetts and on visual observation at sites in the South Coastal Basin, southeastern Massachusetts. Measured or observed zero flow(s) during months of extended drought as defined by the 310 Code of Massachusetts Regulations
(CMR) 10.58(2)(a) were not considered when designating the perennial or intermittent status of a stream site. The database used to develop the equation included a total of 305 stream sites ( 84 intermittent- and 89 perennial-stream sites in the State, and 50 intermittent- and 82 perennial-stream sites in the South Coastal Basin). Stream sites included in the database had drainage areas that ranged from 0.14 to 8.94 square miles in the State and from 0.02 to 7.00 square miles in the South Coastal Basin.

Results of the logistic regression analysis indicate that the probability of a stream flowing perennially at a specific site in Massachusetts can be estimated as a function of (1) drainage area (cube root), (2) drainage density, (3) areal percentage of stratified-drift deposits (square root), (4) mean basin slope, and (5) location in the South Coastal Basin or the remainder of the State. Although the equation developed provides an objective means for estimating the probability of a stream flowing perennially at a specific site, the reliability of the equation is constrained by the data used to develop the equation. The equation may not be reliable for (1) drainage areas less than 0.14 square mile in the State or less than 0.02 square mile in the South Coastal Basin, (2) streams with losing reaches, or (3) streams draining the southern part of the South Coastal Basin and the eastern part of the Buzzards Bay Basin and the entire area of Cape Cod and the Islands Basins. 


\section{INTRODUCTION}

The Commonwealth of Massachusetts Rivers Protection Act (Chapter 258 of the Acts of 1996; The Commonwealth of Massachusetts, 1996) specifies that riverfront areas be protected on all rivers that flow on a year round basis. The Massachusetts Department of Environmental Protection (MADEP) adopted regulations to enforce the law, which defines rivers that flow on a year round basis as perennial streams. The riverfront area is defined in 310 Code of Massachusetts Regulations (CMR) 10.58(2)(a) (hereafter referred to as the Regulations) as the $200-\mathrm{ft}$ wide area extending along the length of each side of the stream from the mean annual high-water line on each side of perennial streams, with exceptions in some urban areas (Massachusetts Department of Environmental Protection, 2000, p. 393-402). The Regulations define the mean annual high-water line as the line that is apparent from visible markings or changes in the character of soils or vegetation due to prolonged presence of water and that also distinguishes predominantly aquatic from predominately terrestrial land. Streams that do not flow on a year round basis, intermittent streams, have no jurisdictional riverfront area along the stream. City or town conservation commissions are charged with administering the Regulations by determining the perennial or intermittent status of a stream site and by regulating work in the riverfront areas. The MADEP addresses appeals of decisions made about the perennial or intermittent status of stream sites by city or town conservation commissions. The logistic regression equation provides these agencies with an additional method for assessing the status of stream sites.

A river is defined in the Regulations as any natural flowing body of water that discharges into an ocean, lake, pond, or another river, and which flows throughout the year (Massachusetts Department of Environmental Protection, 2000, p. 394). Perennial streams are rivers, but intermittent streams are not rivers. The Regulations specify that perennial streams be represented as such on the most current U.S. Geological Survey (USGS) topographic map or on a more recent map developed by the MADEP (if available), unless a competent source can provide adequate evidence to the contrary. A stream site shown as intermittent on USGS or MADEP maps or a site not shown on either of these two maps can be considered perennial if (1) evidence can be established of the presence of aquatic invertebrates that require perennial flows, or (2) evidence of a stream order of two or greater, or (3) there is a USGS streamflow-gaging station upstream from the stream site, or (4) the drainage area upstream from the stream site is greater than $3 \mathrm{mi}^{2}$, except in the Buzzards Bay Basin, Cape Cod Basin, Islands Basin, South Coastal Basin, and Taunton River Basin, or (5) other credible evidence is available. To the contrary, a stream site shown as perennial on USGS or MADEP maps can be considered intermittent if (1) the river at the site is observed not flowing, provided the observation is not during an extended drought, or (2) no stream channel or banks are present, or (3) soils information shows that the ground-water elevation is not at or near the streambed, or (4) other credible evidence is available. A problem, however, is that USGS topographic maps are not made to the level of detail and accuracy presumed by the Regulations; therefore, they may not accurately represent whether a stream site is perennial or intermittent. The USGS, therefore, in cooperation with the Massachusetts Executive Office of Environmental Affairs (MAEOEA) and the MADEP, began a study in 1999 to develop a statistical method to more accurately determine whether a stream at a specific site is perennial or intermittent in Massachusetts.

\section{Purpose and Scope}

This report describes the development and application of a logistic regression equation for estimating the probability of a stream flowing perennially at a specific site in Massachusetts. The equation is based on historical streamflow data in Massachusetts from water years ${ }^{1} 1960$ through 1998 and on field data collected as a pilot project in the South Coastal Basin during the summer of 1999. Basin characteristics used in the analysis were obtained from digital data layers. Limitations of the logistic regression are discussed and areas for further study are presented.

\footnotetext{
${ }^{1} \mathrm{~A}$ water year is the 12 -month period beginning October 1 and ending September 30. It is designated by the calendar year in which it ends.
} 


\section{Acknowledgments}

The authors thank the MADEP's Perennial/ Intermittent Advisory Committee; the MADEP, Bureau of Resource Protection, Wetlands and Waterways Program; MAEOEA, Massachusetts Watershed Initiative; and George Zoto of the MAEOEA for providing input on the State's and South Coastal Basin's perspective related to perennial/intermittent issues. The authors also thank Gregory F. Koltun, USGS, for providing statistical assistance for the study.

\section{DESCRIPTION OF STUDY AREA}

The geography, climate, and surficial geology of a basin upstream of a selected stream site are factors that can affect whether the stream at that location will be perennial or intermittent. In Massachusetts and the South Coastal Basin these factors, and particularly the extent and type of surficial deposits, affect streamflow characteristics.

\section{Characteristics of Massachusetts}

Massachusetts encompasses $8,093 \mathrm{mi}^{2}$ in the northeastern United States (fig. 1). Altitudes range from 1 to $2 \mathrm{ft}$ above sea level in coastal areas to more than 3,900 ft above sea level in the northwest. The climate in Massachusetts is humid. Average annual precipitation ranges from about 40 to 45 in. in eastern Massachusetts and from about 40 to 50 in. in western Massachusetts where higher altitudes may cause orographic effects. Average annual temperature is about $50^{\circ} \mathrm{F}$ in eastern Massachusetts and about $45^{\circ} \mathrm{F}$ in western Massachusetts.

Surficial deposits that overlie bedrock in most of Massachusetts were deposited mainly during the last glacial period, but can include areas of recent floodplain alluvium deposits. In this report, these surficial deposits are classified as either till (which includes till or bedrock, sandy till over sand, and end moraine deposits) or stratified-drift deposits (which includes sand and gravel, large sand, fine-grained, and floodplain alluvium deposits). This classification maintains consistency with characterizations of surficial deposits reported in four reports that discuss low-flow characteristics in Massachusetts (Ries, 1994a; 1994b; and 1997; Ries and Friesz, 2000). Till, an unsorted, unstratified mixture of clay, silt, sand, gravel, cobbles, and boulders, was deposited by glaciers directly on bedrock throughout much of the State. Till primarily is found in the upland areas. Stratified drift is a common term for sorted, layered glaciofluvial and glaciolacustrine deposits. Glaciofluvial deposits are material of all grain sizes (clay, silt, sand, gravel, and cobbles) deposited by glacial meltwater streams in outwash plains and valleys. Glaciolacustrine deposits generally consist of clay, silt, and fine sand deposited in temporary lakes that were present after the retreat of the glacial ice sheet. Stratified-drift deposits are more wide spread in eastern Massachusetts than in western Massachusetts (Ries, 1994a, p. 6). In eastern Massachusetts, stratifieddrift deposits overlie till deposits, particularly in the southeast. In other areas of the State, stratified-drift deposits are more likely to be in river valleys.

The extent and types of surficial deposits are important factors that help explain flow characteristics of Massachusetts streams (Ries, 1994a; 1994b; and 1997; Ries and Friesz, 2000). Till and fine-grained stratified-drift deposits generally have a lower infiltration capacity than medium- to coarse-grained stratifieddrift deposits. The lower infiltration capacity of these materials results in greater direct runoff of precipitation; therefore, less precipitation is available to infiltrate the soil and recharge the aquifer than from medium- to coarse-grained stratified-drift deposits. During dry periods, the primary source of streamflow is ground-water discharge from the aquifer to the stream. Thus, basins underlain predominantly by till and finegrained stratified-drift deposits generally have a lower streamflow per unit area during dry periods than basins underlain predominantly by medium- to coarse-grained stratified-drift deposits.

\section{Characteristics of South Coastal Basin}

The South Coastal Basin is one of 27 river basins in the State, and encompasses $240 \mathrm{mi}^{2}$ in southeastern Massachusetts (fig. 2). The basin includes all or part of 18 towns. Altitudes range from 1 to $2 \mathrm{ft}$ above sea level to about $400 \mathrm{ft}$ above sea level. The basin mainly has low relief and is characterized by low-gradient streams. 


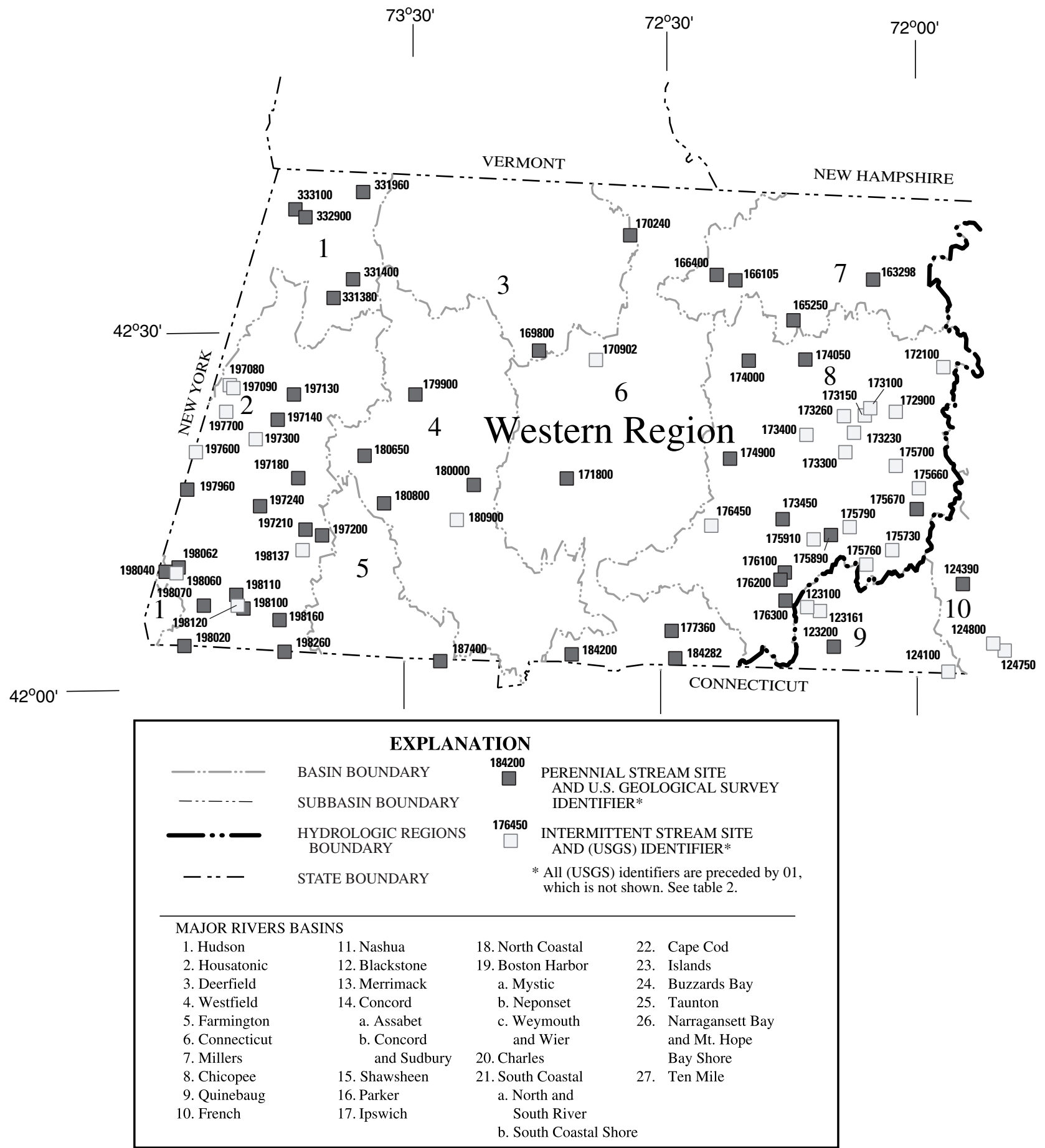

Figure 1. Location of discontinued and continuous streamflow-gaging stations and partial-record stations designated as perennial or intermittent stream sites used in development of the logistic regression equation for estimating the probability of a stream flowing perennially in Massachusetts. 


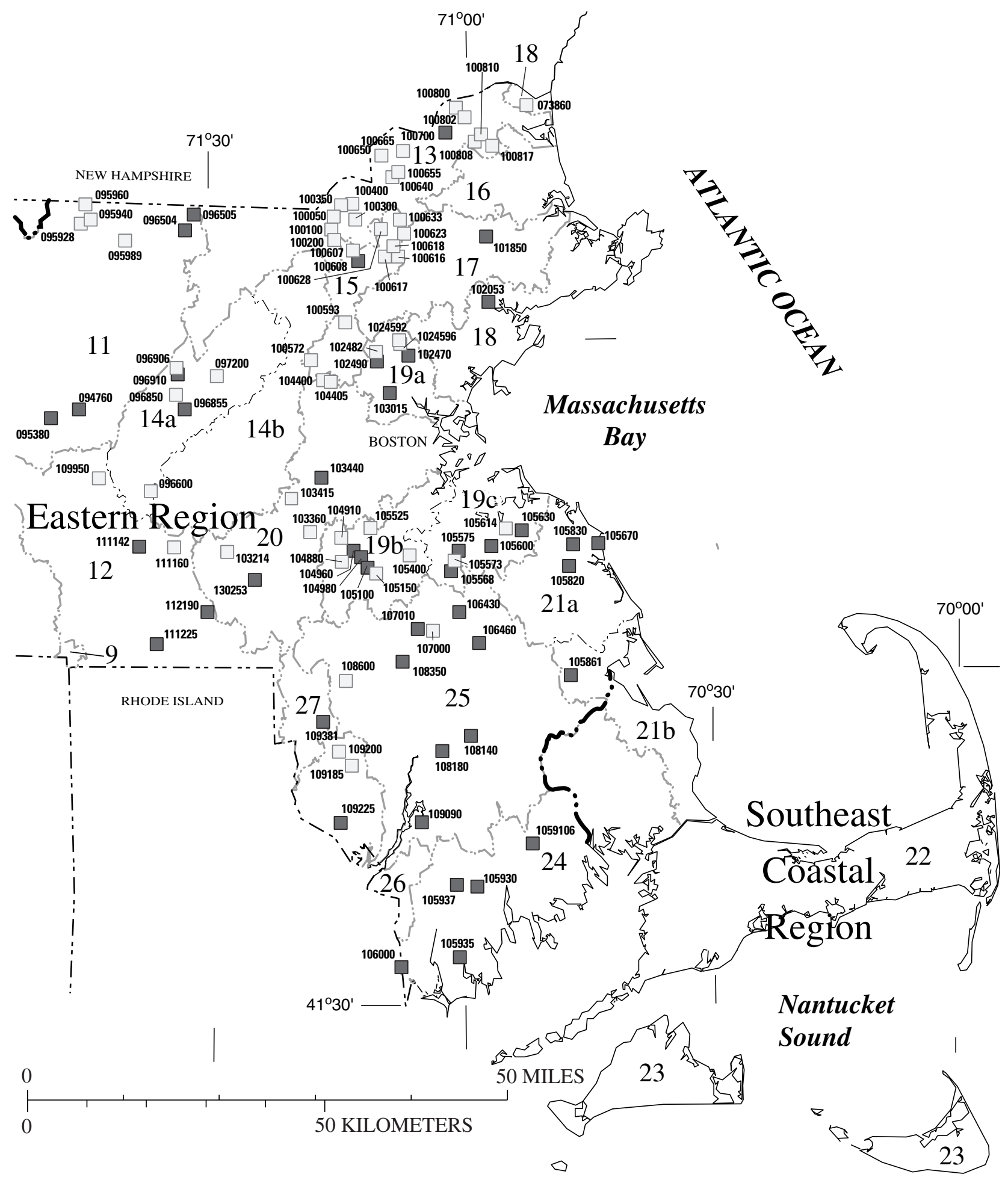

Figure 1. Location of discontinued and continuous streamflow-gaging stations and partial-record stations designated as perennial or intermittent stream sites used in development of the logistic regression equation for estimating the probability of a stream flowing perennially in Massachusetts-Continued. 


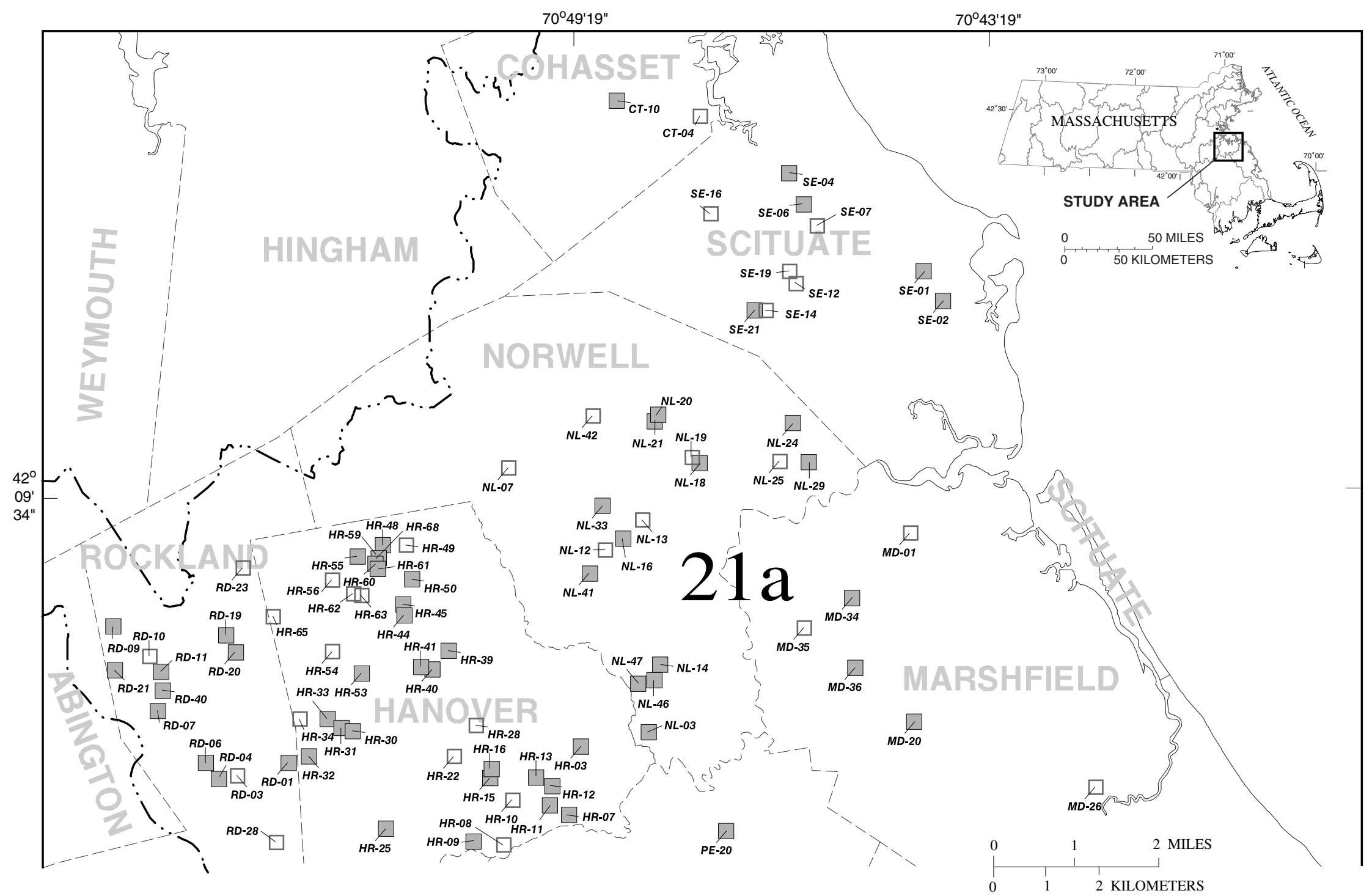




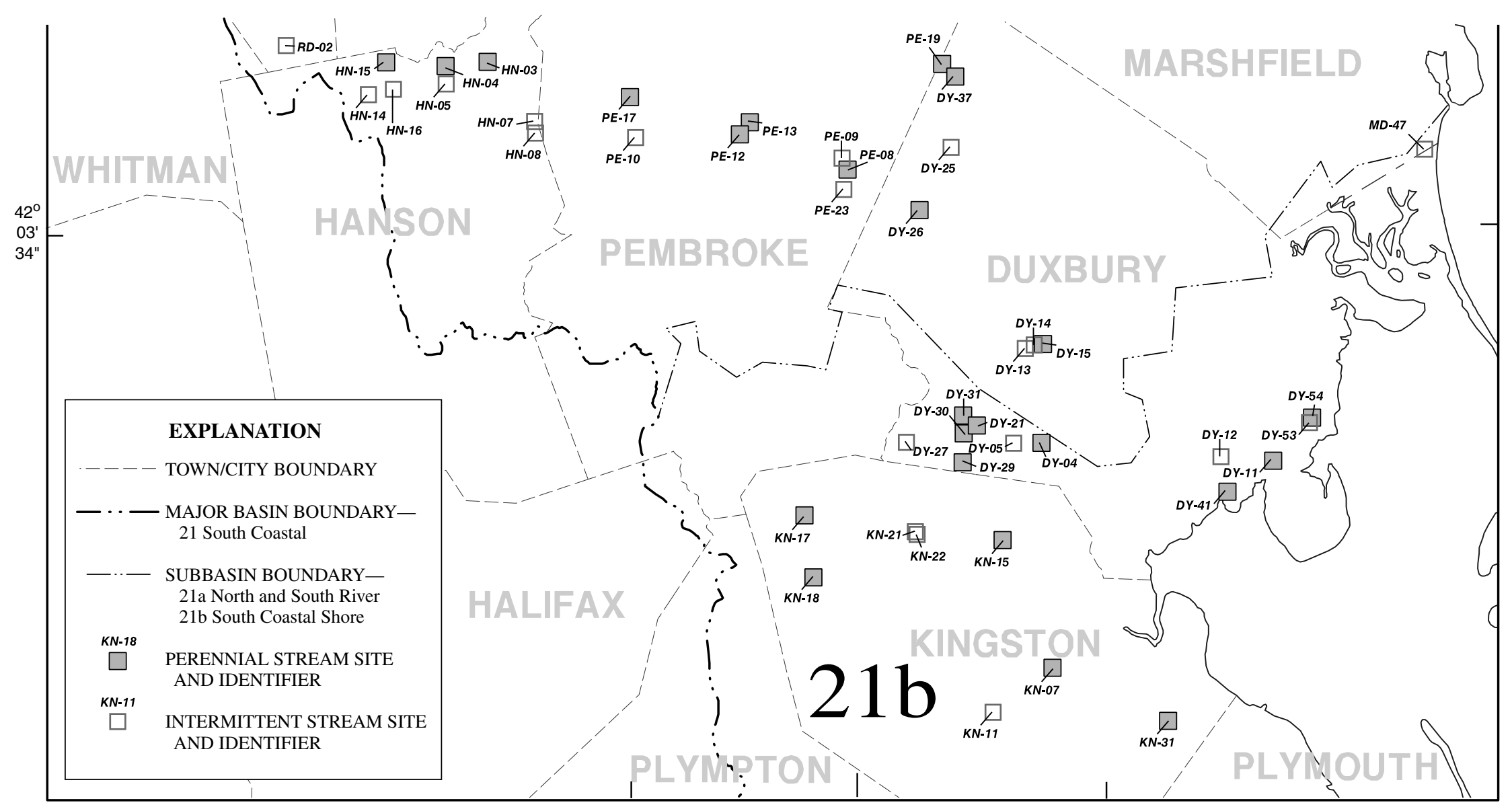

Figure 2. Location of field visited stream sites in the South Coastal Basin, southeastern Massachusetts, designated as perennial or intermittent stream sites used in development of the logistic regression equation for estimating the probability of a stream flowing perennially in Massachusetts. 
Surficial geology is mainly stratified-drift deposits, as 65 percent of the $240-\mathrm{mi}^{2}$ basin is underlain by these deposits and the remaining area (35 percent) is underlain by till and bedrock. However, surficial geology in the basin is distinctly different from the northern $105 \mathrm{mi}^{2}$ (North and South River Subbasins), where about 33 percent of the area is underlain by stratified-drift deposits, and from the southern $135 \mathrm{mi}^{2}$ (South Coastal Shore Subbasin), where about 90 percent of the area is underlain by stratified-drift deposits (Ries, 1994b).

\section{DATABASE DEVELOPMENT}

To develop an equation for estimating the probability of a Massachusetts stream flowing perennially at a specific site, a database was developed that contains basin characteristic information on both perennial- and intermittent-stream sites in the State. Development of this database involved screening data to avoid entries for stream sites affected by regulation, drought conditions, or other factors that may alter the perennial or intermittent status of streams. The stream sites were selected from the USGS database of measured streamflow in the State from water years 1960 through 1998 and from sites visited in the South Coastal Basin in the summer of 1999.

\section{Factors That Affect the Perennial/Intermittent Status of Streams}

For this study, determination of the perennial or intermittent status of a stream site in Massachusetts was completed only for naturally flowing streams (no regulation). Regulated streams are those affected by dams, surface-water withdrawals, ground-water withdrawals (pumping wells), diversions, wastewater discharges, and so forth. The perennial or intermittent status of a stream at a specific site cannot be estimated accurately if the flows above or near the site are regulated, because regulations vary from site to site, and the majority of regulations are not quantified or easily quantifiable. Observations of no flow at stream sites during abnormally dry periods and observations of flow at stream sites during abnormally wet periods were not included in the study database, to avoid observations that are unrepresentative of normal climatic conditions.

If zero flows were measured in the eastern or western region of the State during a month that occurred within an extended drought, as defined in the Regulations, those flows were not included in the database. The months that met the definition of an extended drought for both the eastern and western regions are listed in table 1.

The Regulations define an extended drought as a period of below normal precipitation for that month and the three previous months, with at least 3 of the months having 75 percent or less of the normal precipitation and 2 months having 50 percent or less of normal precipitation (Massachusetts Department of Environmental Protection, 2000, p. 395). This definition was used to analyze precipitation records from January 1960 through August 1999 (the period of measured streamflow used for development of the database) at 19 index-precipitation stations in the State (fig. 3), which included 10 index-precipitation stations from the eastern region and 9 index-precipitation stations from the western region. Although the NWS (National Weather Service) precipitation station in Ashburnham is about $1 \mathrm{mi}$ within the eastern region boundary (fig. 3), it was used for the western region, because there were no other index stations in the eastern part of the western region. The Massachusetts Department of Environmental Management (MADEM) maintains the database of precipitation measured at these index-precipitation stations.

To determine when the eastern or western regions met the Regulation's extended drought definition, the following steps were used (1) the average long-term monthly precipitation for June 1960 through August 1999 was determined for each of the 19 index stations, (2) the average long-term monthly precipitation for the eastern region was determined by calculating the average long-term monthly precipitation (determined in step 1) of the 10 index stations and was determined for the western region by calculating the average long-term monthly precipitation (determined in step 1) of the 9 index stations, (3) the average monthly precipitation for each individual month and 
Table 1. Months that the eastern or western regions of Massachusetts met the 310 Code of Massachusetts Regulations (CMR) 10.58(2)(a) definition of extended drought from January 1960 through August 1999

[Monthly precipitation average based on Massachusetts Department of Environmental Management precipitation data. The eastern region is based on precipitation stations at Brockton, Buffumville Lake, Concord, Falmouth, Lawrence, Lowell, Middleborough, New Bedford, Northbridge, and Waltham. The western region is based on precipitation stations at Amherst, Ashburnham, Chesterfield, Dalton, Greenfield, Otis, Plainfield, Stockbridge, and Worthington. Precipitaiton station locations shown in figure 3]

\begin{tabular}{|c|c|}
\hline Month & Year \\
\hline \multicolumn{2}{|l|}{ Eastern region } \\
\hline June........ & 1964 \\
\hline August .................... & 1964 \\
\hline May........................ & 1965 \\
\hline 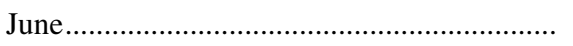 & 1965 \\
\hline July & 1965 \\
\hline 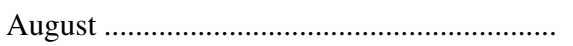 & 1965 \\
\hline January .................... & 1966 \\
\hline 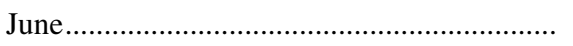 & 1966 \\
\hline September & 1968 \\
\hline October ................. & 1968 \\
\hline February.................... & 1980 \\
\hline 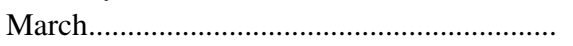 & 1980 \\
\hline March................ & 1981 \\
\hline November ......... & 1984 \\
\hline April.................. & 1985 \\
\hline 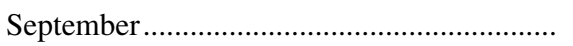 & 1988 \\
\hline 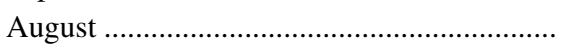 & 1993 \\
\hline 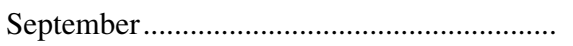 & 1997 \\
\hline \multicolumn{2}{|l|}{ Western region } \\
\hline November ........ & 1964 \\
\hline December........... & 1964 \\
\hline January ................ & 1965 \\
\hline May........................ & 1965 \\
\hline June & 1965 \\
\hline February & 1968 \\
\hline 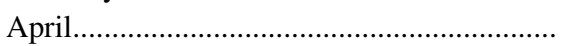 & 1978 \\
\hline 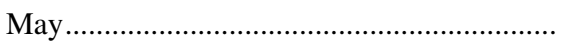 & 1978 \\
\hline 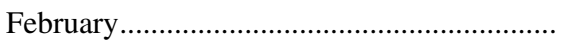 & 1980 \\
\hline 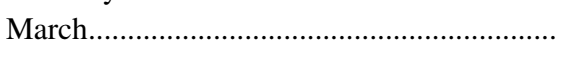 & 1980 \\
\hline 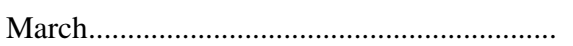 & 1981 \\
\hline 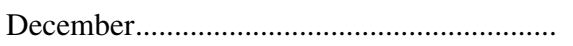 & 1988 \\
\hline 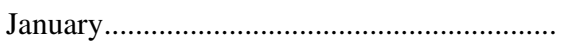 & 1989 \\
\hline
\end{tabular}

year for the eastern region was determined by calculating the average monthly precipitation for the 10 index stations and was determined for the western region by calculating the average monthly precipitation for the 9 index stations, and (4) the regional average monthly precipitation for each individual month and year (determined in step 3) was then tested against the regional average long-term monthly precipitation (determined in step 2) to determine if each month in each region from January 1960 through August 1999 met the extended drought definition. This definition eliminated 3.8 percent of the months in the eastern region and 2.7 percent of the months in the western region during January 1960 through August 1999 (table 1).

Because the Regulations have no operational definition of an abnormally wet month, only those perennial-stream sites measured at least three times were included in the database. By measuring a perennialstream site at least three times, it would be likely that at least one measurement was made during relatively normal climatic conditions.

\section{Site Selection}

Selecting stream sites for inclusion in the database of perennial- and intermittent-stream sites in Massachusetts involved (1) reviewing available USGS measured streamflow data from sites in the State (table 4, at back of report), and (2) visiting sites in the South Coastal Basin (table 5, at back of report). A list of perennial-stream sites in the State was available from Ries (1997), in which equations were developed to estimate the August median streamflow at ungaged sites in Massachusetts. Locations of intermittent-stream sites were determined through review of streamflow-measurement data collected from sites in the State. Stream sites in the South Coastal Basin (fig. 2) were evaluated visually in the field during the summer of 1999, to determine their perennial or intermittent status. As part of the stream-site-selection process, stream sites were accessed with the World Wide Web application STREAMSTATS, http://ma.water.usgs.gov/streamstats/ (Ries and others, 2000), to determine if there were public community surface-water or ground-water withdrawals upstream of or nearby the sites. 


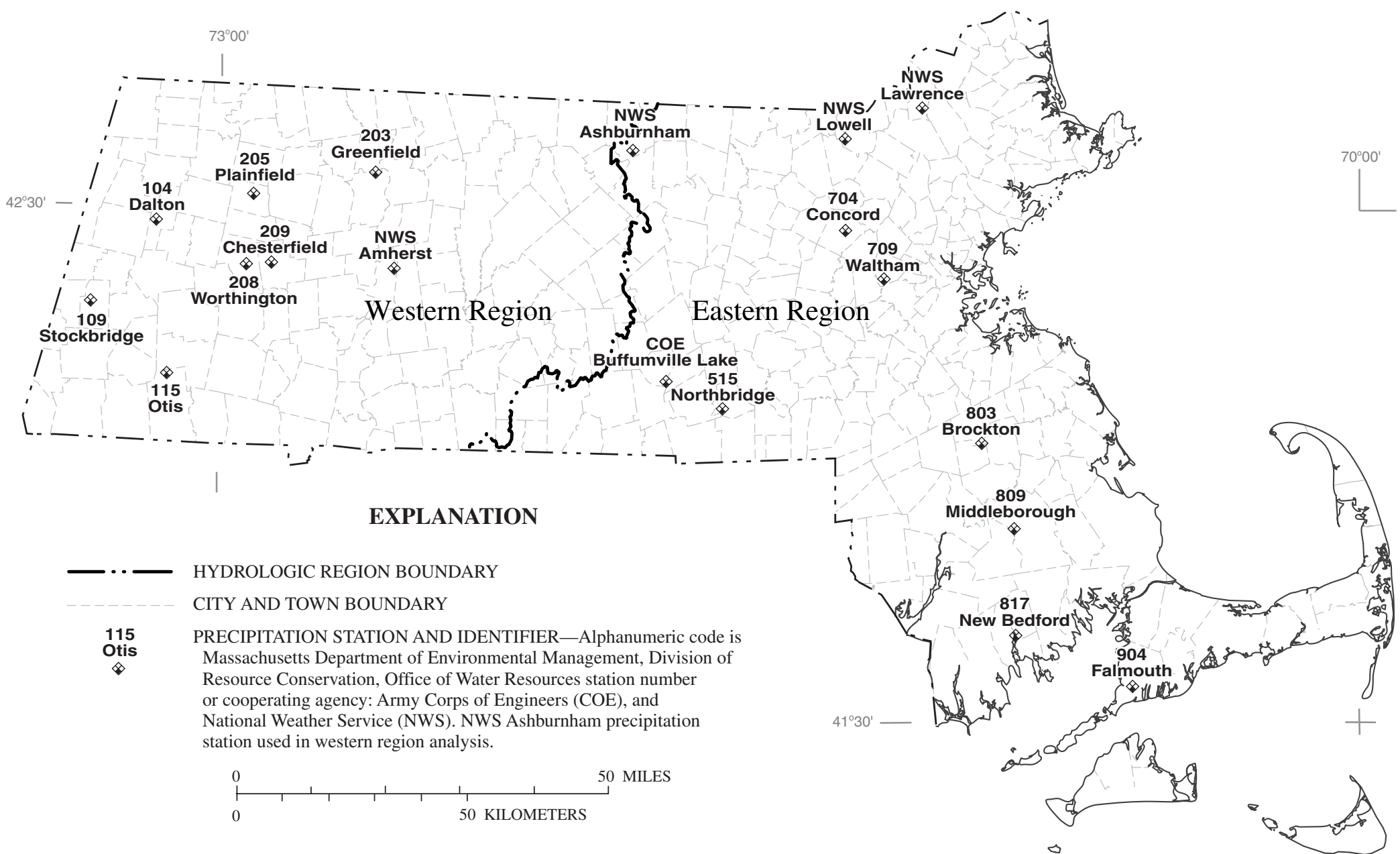

Figure 3. Location of precipitation stations analyzed to determine if the eastern region or western region of Massachusetts met the 310 Code of Massachusetts Regulations (CMR) 10.58(2)(a) definition of extended drought. 
Approximately 1,300 stream sites (partialrecord, discontinued streamflow-gaging, or continuous streamflow-gaging stations) in the USGS National Water Information System (NWIS) database were evaluated for measured zero flow(s) for water years 1960 through 1998 to determine intermittent sites in Massachusetts. Of these 1,300 stream sites, zero flow(s) had been measured at 174 sites. Of these 174 stream sites, 90 sites were omitted from the database because of one or more of the following conditions: (1) regulation of streamflow by dams, groundwater or surface-water withdrawals upstream or nearby, diversions, wastewater discharges, and so forth, (2) zero flow(s) measured only during an extended drought period, (3) the stream site was outside of Massachusetts, (4) questionable streamflow measurements, (5) the stream site was in the Buzzards Bay, North Coastal, or Taunton River Basins (where no digitized stream-network-data layers were available for these three basins in STREAMSTATS as of March 1, 2001), and (7) the site was in the Cape Cod Basin, Islands Basin, southern part of the South Coastal Basin, or eastern part of the Buzzards Bay Basin (labeled as Southeast Coastal Region in fig. 1) where the areas contributing ground water and surface water to a specific stream site may be appreciably different. Only 84 zero-flow sites from the USGS NWIS database of approximately 1,300 stream sites met these criteria and were used as part of the intermittent-stream sites in Massachusetts. These stream sites had a maximum drainage area of $8.04 \mathrm{mi}^{2}$ (station 01175790 ), a minimum drainage area of $0.14 \mathrm{mi}^{2}$ (stations 01100572 , 01100618, and 01100623), a mean drainage area of $2.63 \mathrm{mi}^{2}$, and a median drainage area of $2.02 \mathrm{mi}^{2}$ (table 4).

An initial list of perennial-stream sites in Massachusetts was created from the 205 sites used by Ries (1997). Of the 205 stream sites, 116 sites were omitted from the database because of one or more of the following conditions: (1) regulation of streamflows by dams, ground-water or surface-water withdrawals upstream or nearby, diversions, wastewater discharges, and so forth, (2) the stream site previously was identified as an intermittent (zero flow) site, and (3) the drainage area of the stream site was greater than $9.00 \mathrm{mi}^{2}$ (the intermittent-stream sites had a maximum drainage area of $8.04 \mathrm{mi}^{2}$ ) and would not aid in development of the logistic regression equation. The remaining 89 perennial-stream sites included in the database had a maximum drainage area of $8.94 \mathrm{mi}^{2}$ (station 01106460), a minimum drainage area of $0.78 \mathrm{mi}^{2}$ (station 01197210), a mean drainage area of $5.16 \mathrm{mi}^{2}$, and a median drainage area of $5.27 \mathrm{mi}^{2}$ (table 4).

In the South Coastal Basin, 397 stream sites were visited from June through August 1999. These stream sites were at road crossings where access permitted a visual inspection to determine if there were flow in the stream. These stream sites were evaluated during periods of little to no precipitation that occurred at least 3 to 5 days following a precipitation event totaling 0.10 in. or greater. Observations recorded during the visual inspection at each stream site included whether the streambed was dry, had disconnected pools of water in the streambed, had water but no velocity (no flowing water), or had flowing water. The stream sites were inspected on both the upstream and downstream sides of each road crossing and documented with digital photographs of the upstream and downstream stream-channel conditions at each site. Those stream sites with a dry streambed or disconnected pools of water were classified as intermittent on the basis of on the definition that perennial streams are rivers that flow throughout the year. 
Of the 397 stream sites visited in the South Coastal Basin, 261 sites were omitted because of one or more of the following conditions: (1) regulation of streamflows by dams, ground-water or surface-water withdrawals upstream or nearby, diversions, waste- water discharges, and so forth, (2) no visible streambed observed in the field, although the site was shown as a stream on a USGS topographic map, (3) water but no velocity observed at the stream site (a velocity was not verified with a flow meter; therefore, the perennial or
A

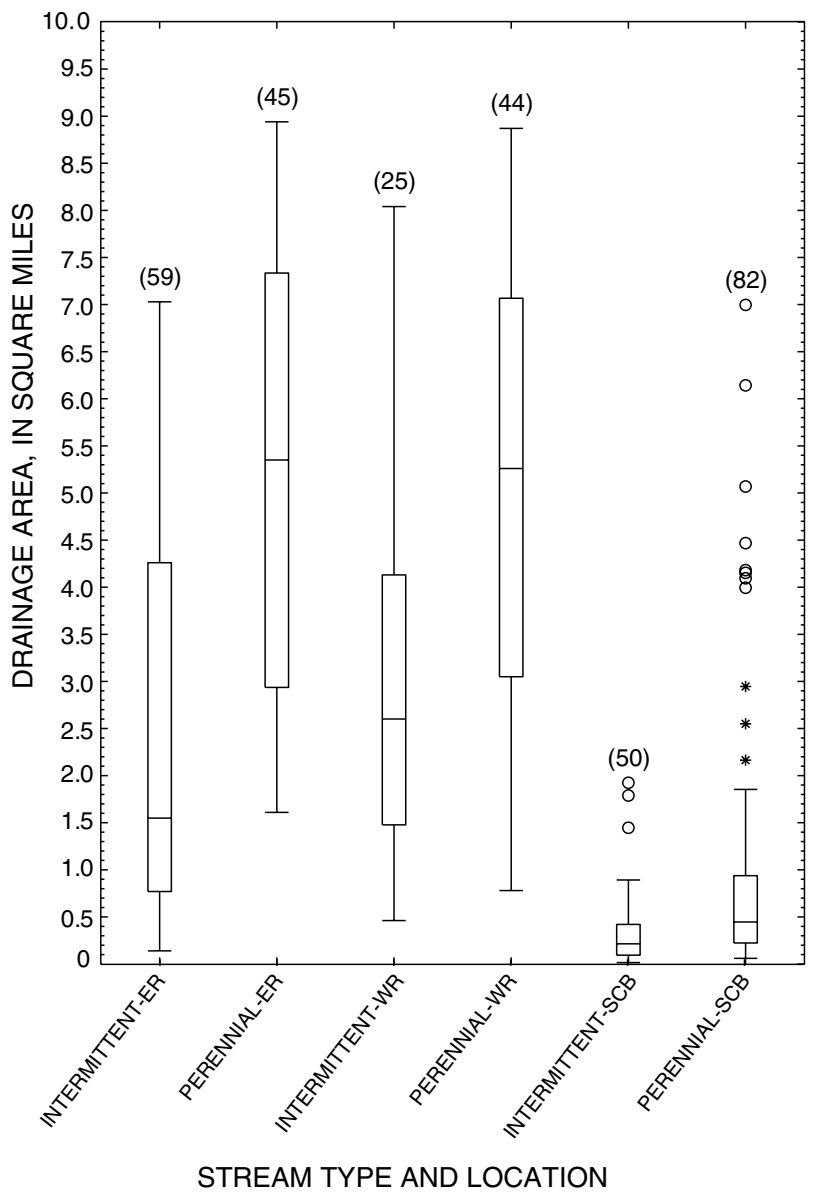

B.

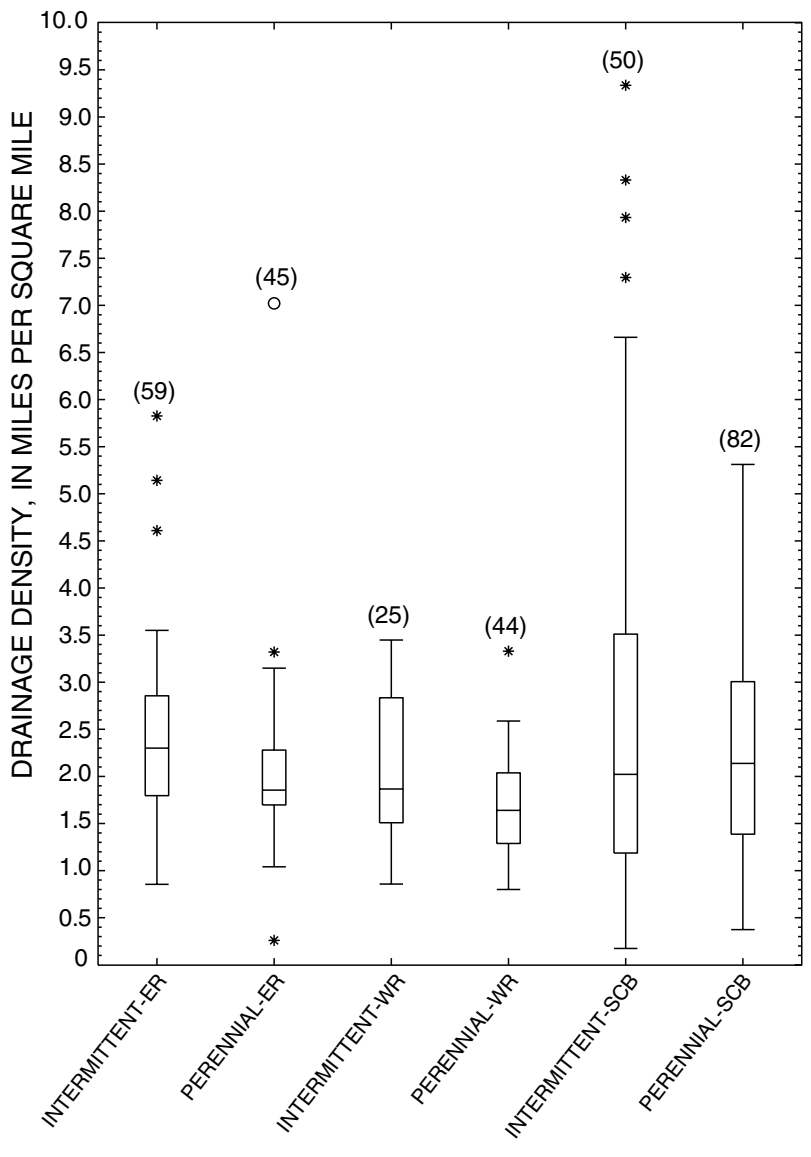

STREAM TYPE AND LOCATION

EXPLANATION

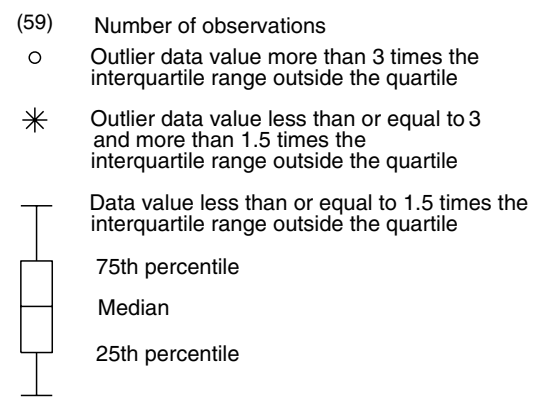

Figure 4. Distribution of $(A)$ drainage area, $(B)$ drainage density, $(C)$ areal percentage of stratified-drift deposits, and $(D)$ mean basin slope for intermittent- and perennial-stream sites in the eastern region (ER), western region (WR), and South Coastal Basin (SCB) of Massachusetts used in development of the logistic regression equation for estimating the probability of a stream flowing perennially in Massachusetts. 
intermittent status could not be determined), (4) the stream site was just outside the South Coastal Basin, (5) no digitized stream-network data were available for the stream site in STREAMSTATS (because the stream is not shown on a USGS topographic map),
(6) the shape of the drainage-basin boundary drawn by STREAMSTATS did not match that determined from USGS topographic maps [because small drainage areas in low slope areas, such as the South Coastal Basin (fig. 4D), determined from STREAMSTATS

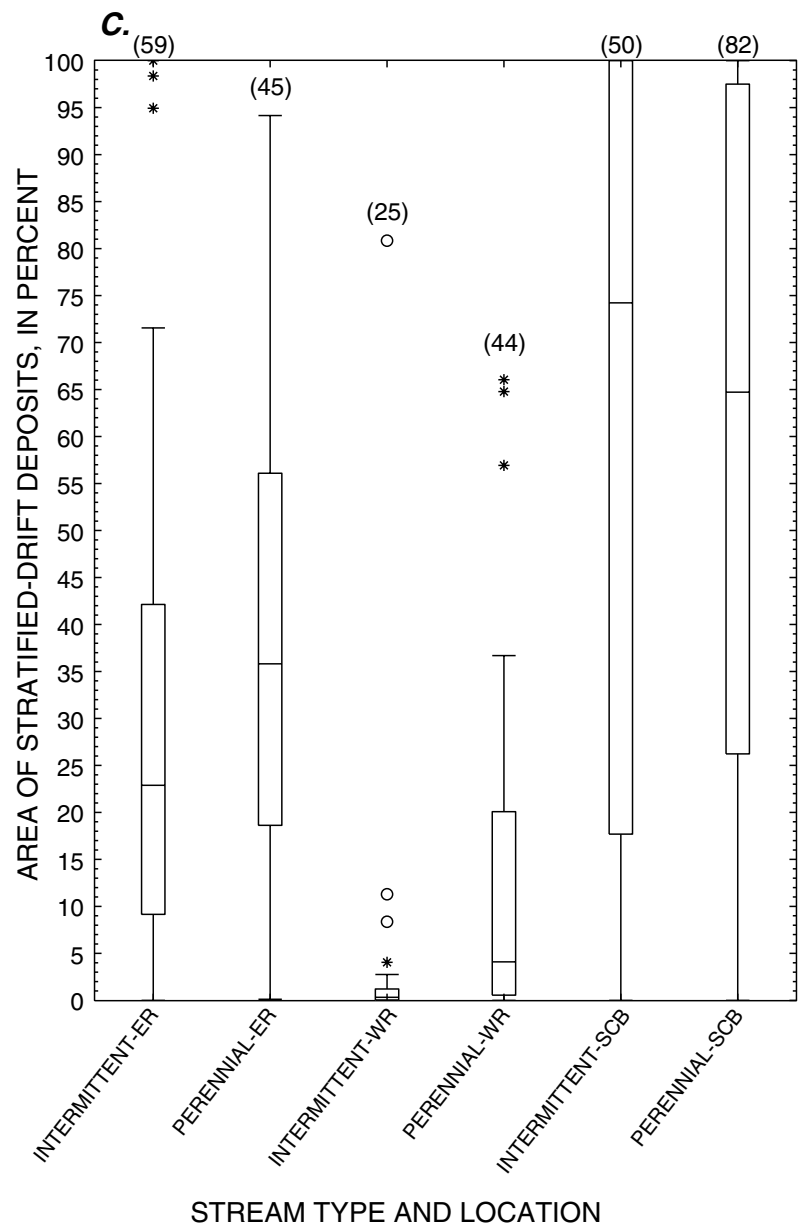

$D$.

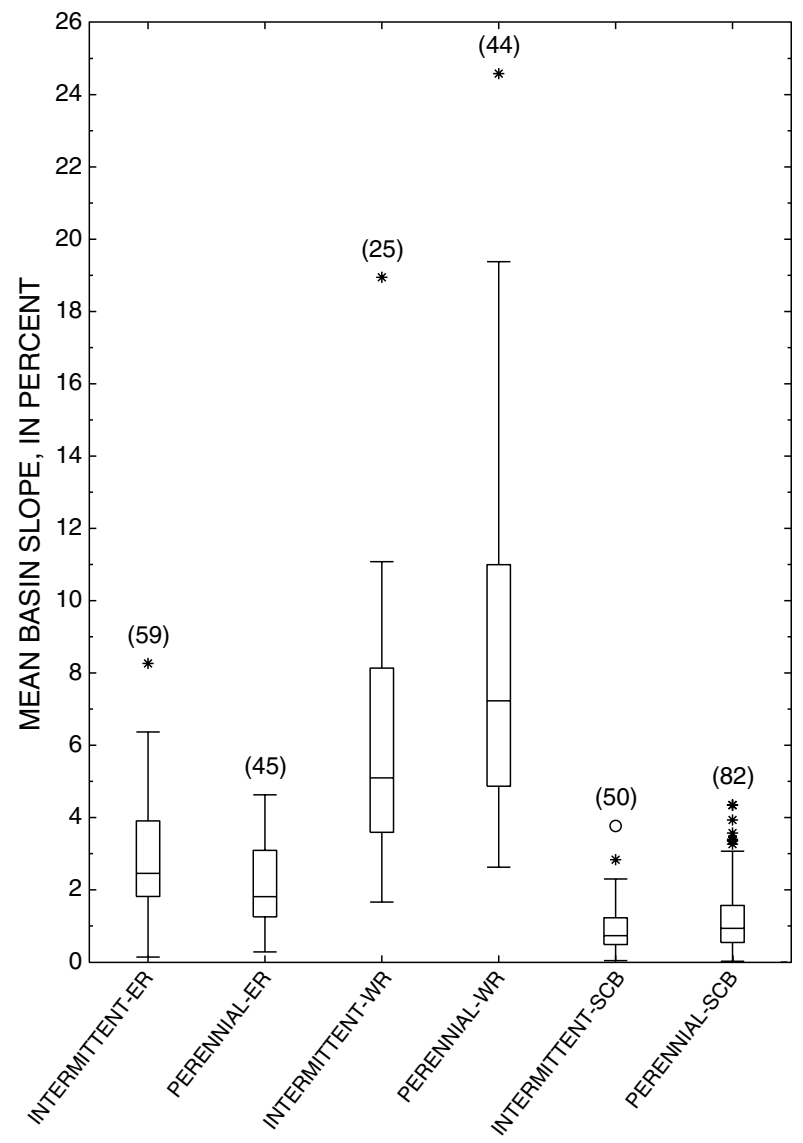

STREAM TYPE AND LOCATION

EXPLANATION

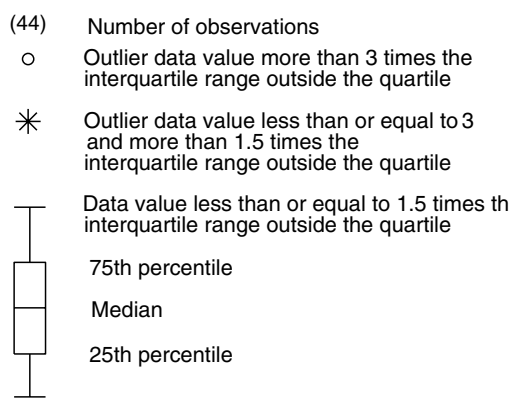

Figure 4. Distribution of $(A)$ drainage area, $(B)$ drainage density, $(C)$ areal percentage of stratified-drift deposits, and $(D)$ mean basin slope for intermittent- and perennial-stream sites in the eastern region (ER), western region (WR), and South Coastal Basin (SCB) of Massachusetts used in development of the logistic regression equation for estimating the probability of a stream flowing perennially in Massachusetts-Continued. 
sometimes may not compare well to drainage areas for stream sites determined from topographic maps (P.A. Steeves, U.S. Geological Survey, oral commun., 2000)], and (7) the drainage area was greater than $9.00 \mathrm{mi}^{2}$. These criteria resulted in 50 intermittent- and 82 perennial-stream sites in the South Coastal Basin being included in the database. The intermittent-stream sites had a maximum drainage area of $1.92 \mathrm{mi}^{2}$ (station NL-19), a minimum drainage area of $0.02 \mathrm{mi}^{2}$ (station $\mathrm{NL}-42$ ), a mean drainage area of $0.34 \mathrm{mi}^{2}$, and a median drainage area of $0.21 \mathrm{mi}^{2}$ (table 5). The perennial-stream sites had a maximum drainage area of $7.00 \mathrm{mi}^{2}$ (station HR-30), a minimum drainage area of $0.06 \mathrm{mi}^{2}$ (station HR-03), a mean drainage area of $1.00 \mathrm{mi}^{2}$, and a median drainage area of $0.45 \mathrm{mi}^{2}$ (table 5). The final database used in the analysis contained 305 stream sites, of which 134 sites were identified as intermittent, and 171 sites were identified as perennial.

\section{SELECTION AND MEASUREMENT OF BASIN CHARACTERISTICS}

Basin characteristics for most stream sites were determined with STREAMSTATS (Ries and others, 2000), unless the characteristics for a site had been determined for the Statewide August median streamflow study by Ries (1997). STREAMSTATS was not used to verify basin characteristics determined in Ries (1997), because digital data layers were the same and STREAMSTATS is an automated procedure of the technique used in the earlier study. The basincharacteristics values determined for possible use in developing a logistic regression equation are drainage area, length of streams, area of stratified drift, and mean basin slope. Ries and Friesz (2000) found these characteristics to be the most significant explanatory variables for using regression equations to estimate low-flow characteristics at ungaged sites in Massachu- setts. These characteristics, therefore, also may be important in predicting the probability of a stream flowing perennially at a specific site in Massachusetts.

These four basin characteristics currently (November 1, 2001) are determined by STREAMSTATS. Drainage areas were determined from 1:25,000 scale digital elevation models (DEMs). Length of streams were determined with centerline data of streams from a 1:25,000 scale hydrography digital data layer. The areas of stratified-drift deposits were determined from a 1:250,000 scale surficial geology digital data layer. Mean basin slopes were determined from 1:250,000 scale DEMs.

Drainage density (length of streams divided by drainage area) and the percentage of the drainage area of each basin underlain by stratified drift (area of stratified-drift deposits divided by drainage area) also were determined for each stream site for use in developing a logistic regression equation. Drainage density represents the magnitude per area of a network of streams within a basin for drainage of runoff. The areal percentage of stratified-drift deposits within a basin indicates whether a large or small proportion of the basin contains stratified-drift deposits.

\section{LOGISTIC REGRESSION EQUATION}

Logistic regression is a statistical technique that can be applied in water resources. In this technique, the probability of a result being in one of two response groups (binary response) is modeled as a function of the magnitudes of one or more explanatory variables (Helsel and Hirsch, 1992, p. 393-402). For instance, the probability whether or not a stream site is intermittent or perennial may be modeled as a function of the magnitudes of one or more basin characteristics. For this study, the response variable is " 1 " when the stream is perennial and " 0 " when the stream is intermittent. 
Other studies have used logistic regression to determine the intermittent or perennial status of streams or to investigate other water-resource issues. In a study by Kliever (1996), logistic regression was used to determine the probability that streamflow would be zero for a particular low-flow statistic at a partialrecord station given the same low-flow statistic at nearby index stations in northern Rhode Island. Other applications of logistic regression analyses in water resources have been completed by Eckhardt and others (1989), Eckhardt and Stackelberg (1995), Koltun and Sherwood (1998), and Squillace and others (1999).

\section{Development}

Logistic regression methods were used for estimating the probability of a stream being perennial at a specific site as a function of basin characteristics for the 84 intermittent- and 89 perennial-stream sites in the State and for the 50 intermittent- and 82 perennialstream sites in the South Coastal Basin. Basin characteristics tested in the regression methods were drainage area, drainage density, areal percentage of stratifieddrift deposits, and mean basin slope (tables 4 and 5). Drainage density and areal percentage of stratified-drift deposits represent a more relative measure of how these basin characteristics may affect the probability of a stream flowing perennially. These characteristics, therefore, were chosen over more absolute measures such as length of streams and area of stratified-drift deposits. Also, drainage density and areal percentage of stratified-drift deposits provide a more equal comparison of basins over a wide range of drainage-area sizes, as is the case in this study. Additionally, the four basin characteristics were transformed (square, cube, square root, and cube root), and then tested as possible explanatory variables. Transforming data is a common procedure that makes the data more symmetric, linear, and constant in variance (homoscedasticity) (Helsel and Hirsch, 1992, p. 12-14).
Two additional explanatory variables were tested that indicate whether the stream site was located in the western or eastern region of the State (fig. 1) and whether the site was located in the South Coastal Basin (fig. 2) or in the remainder of the State. The South Coastal Basin stream sites were those visited in the summer of 1999. Four stream sites in the South Coastal Basin, selected from review of the 205 perennialstream sites in Massachusetts used by Ries (1997) (table 4), were not included with those sites visited in the summer of 1999. Massachusetts was split into western and eastern regions on the basis of observed differences in relations between the perennial or intermittent status of streams and their areal percentage of stratified-drift deposits and mean basin slope (figs. $4 C$ and $D$ ).

Median drainage area and drainage density for perennial-stream sites in the eastern region were slightly greater than in the western region (figs. $4 A$ and $B)$. The median areal percentage of stratified-drift deposits for perennial-stream sites in the eastern region was about eight and a half times greater than in the western region (fig. 4C). The median mean basin slope for perennial-stream sites in the eastern region was about three and a half times lower than in the western region (fig. $4 D$ ). For drainage areas from 0.01 to $0.99 \mathrm{mi}^{2}$, the observed frequency of perennial-stream sites was greater in the western region than in the eastern region (figs. 5A and $B$ ). Additionally, Ries (1997) found in a Statewide August median streamflow study that the western region of the State had a higher August median streamflow per unit area than the eastern region. As a result of these tests, the regions were divided along the eastern border of the Connecticut River Basin or the eastern border of the Millers and Chicopee River Basins, which are a part of the Connecticut River Basin (fig. 1). Ries (1997) divided the State along these same borders.

The South Coastal Basin, which is part of the eastern region, was assigned its own location identifier because the data for this area of the State indicates a 

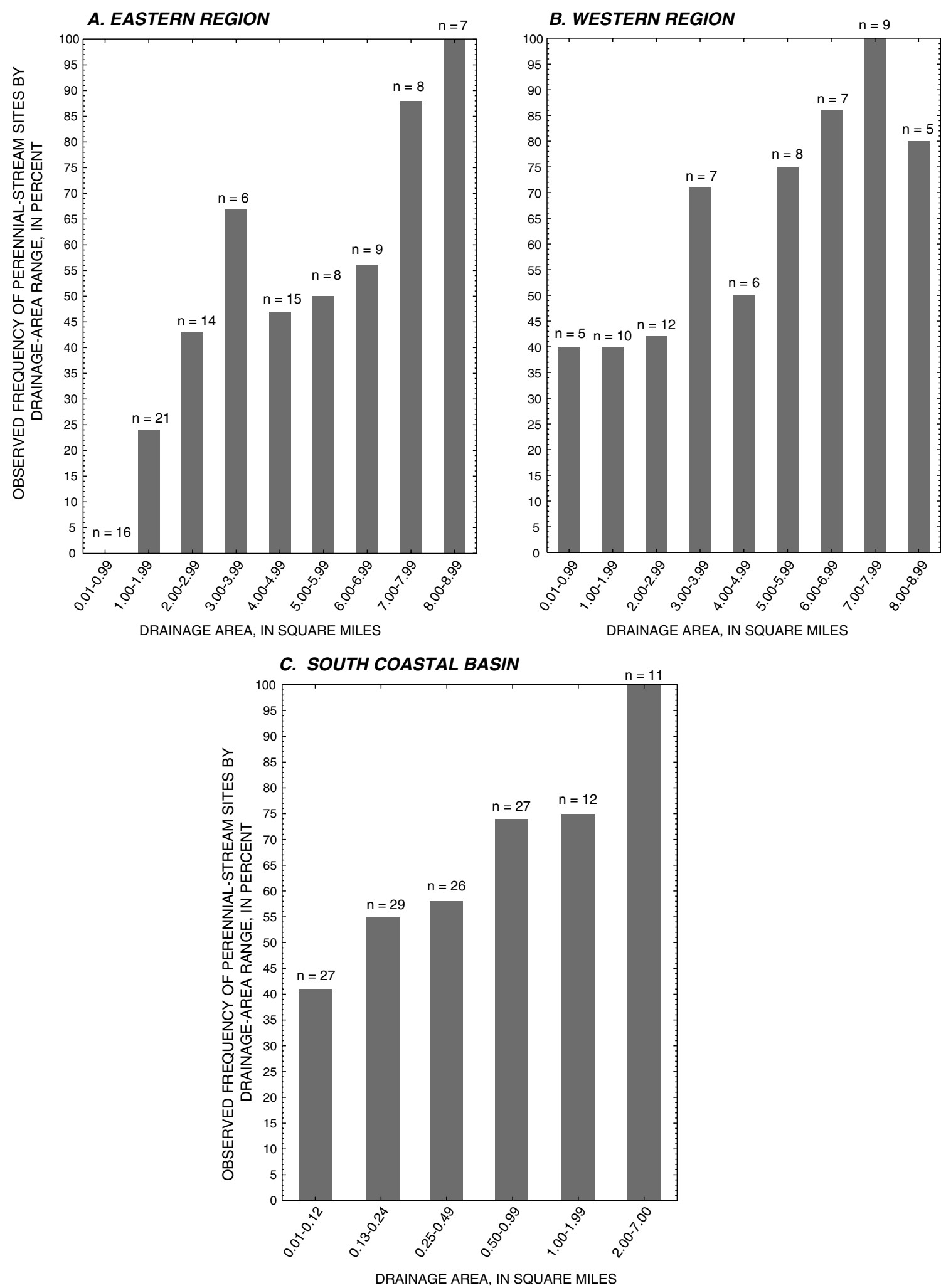

Figure 5. Observed frequency of perennial-stream sites by drainage-area range in the $(A)$ eastern region, $(B)$ western region, and $(C)$ South Coastal Basin of Massachusetts ( $\mathrm{n}$, number of observations). 
different relation between the perennial or intermittent status of stream sites and their drainage area, areal percentage of stratified-drift deposits, and mean basin slope that is different than the relation in the eastern and western regions of the State (figs. $4 A, C$, and $D$ ). For example, drainage area and mean basin slope were lower for stream sites in the South Coastal Basin than in the eastern and western regions, and areal percentage of stratified-drift deposits was greater in the South Coastal Basin than in the eastern and western regions (figs. $4 A, C$, and $D$ ). In the South Coastal Basin, the observed frequency of perennial-stream sites for drainage areas from 0.01 to $0.12 \mathrm{mi}^{2}$ is similar to the observed frequency of perennial-stream sites in the eastern region for drainage areas from 1.00 to $1.99 \mathrm{mi}^{2}$ and in the western region for drainage areas from 0.01 to $0.99,1.00$ to 1.99 , and 2.00 to $2.99 \mathrm{mi}^{2}$ (figs. $5 A-C$ ). This greater observed frequency of a perennial-stream site for small drainage areas in the South Coastal Basin, as compared to the remainder of the State, likely results because of the greater areal percentage of stratified-drift deposit (fig. 4C). If the South Coastal Basin drainage area classes (fig. $5 C$ ) 0.01 to $0.12,0.13$ to $0.24,0.25$ to 0.49 , and 0.50 to $0.99 \mathrm{mi}^{2}$ were combined, the observed frequency of perennial-stream sites would be 55 percent (62 perennial-stream sites of the 113 sites in those classes). This observed frequency of perennialstream sites in the South Coastal Basin (55 percent) is not reached in the eastern region until the drainage area is from 2.00 to $2.99 \mathrm{mi}^{2}$ (fig. $5 \mathrm{~A}$ ), and is not reached in the western region until the drainage area is from 3.00 to $3.99 \mathrm{mi}^{2}$ (fig. $5 B$ ).

After stream sites were evaluated with basin characteristics for any regionalization, logistic regression analyses were done with the SAS statistical software package (SAS Institute, Inc., 1989; 1995). The general form of a logistic regression equation is

$$
P=\frac{\exp \left(b_{0}+b_{1} x_{1}+\ldots+b_{1} x_{1}\right)}{1+\exp \left(b_{0}+b_{1} x_{1}+\ldots+b_{1} x_{1}\right)},
$$

where $P$ is the probability of the condition being true, $\exp$ is the exponential function and is written as $\exp (x)$ or $e^{(x)}$ (where " $e$ " is the base of the natural logarithm and is approximately equal to 2.7183$), b_{0}$ is the intercept, $b_{1 \ldots i}$ is the coefficient for explanatory variable $i$, and $x_{1 \ldots i}$ is the value of explanatory variable $i$. More detailed information on logistic regression can be found in Collett (1991) and Hosmer and Lemeshow (1989).

All potential explanatory variables (basin characteristics; square, cube, square root, and cube root transformations of the basin characteristics; and location identifiers) were evaluated by using the procedures of forward selection, backward elimination, stepwise selection, and best subset selection to help determine the best possible logistic regression equations (SAS Institute, Inc., 1995, p. 51-65). A statistical significance level of 0.05 for $p$-values of explanatory variables was used for entry or retention in the equations. These equations developed during the variable-evaluation process were used for estimating the probabilities that each of the stream sites was perennial.

The results of the equations were summarized in classification tables (SAS Institute, Inc., 1995, p. 4550). These tables provide information about the predictive accuracy of an equation by summarizing the frequency with which observations are correctly and incorrectly classified as events or nonevents for different probability cutpoints. Because the same data are used to develop the equation and to test its predictive accuracy, a method that approximates the unbiased jackknifing procedure was used to create the classification tables (SAS Institute Inc., 1995, p. 45). Jackknifing minimizes bias caused when an independent set of observations is not available to test the predictive accuracy of the equation.

Goodness-of-fit of the potential logistic regression equations were evaluated with the Hosmer and Lemeshow (1989) goodness-of-fit test, which compares the observed to the predicted distribution of outcomes (SAS Institute, Inc., 1995, p. 67-72). Regression diagnostics of the equations also were evaluated to determine how each observation affects the fit of the logistic regression equation (SAS Institute, Inc., 1995, p. 73-79). Finally, receiver-operating-characteristic (ROC) curves were evaluated to assess the predictive accuracy of the logistic regression equation (SAS Institute Inc., 1995, p. 87-92). 
The best logistic regression equation determined from data in this study is:

$$
P=\frac{\exp \left(-5.6325+3.2619\left(x_{1}\right)^{1 / 3}-0.2566\left(x_{2}\right)+0.1248\left(x_{3}\right)^{1 / 2}+0.1929\left(x_{4}\right)+3.3236\left(x_{5}\right)\right)}{1+\exp \left(-5.6325+3.2619\left(x_{1}\right)^{1 / 3}-0.2566\left(x_{2}\right)+0.1248\left(x_{3}\right)^{1 / 2}+0.1929\left(x_{4}\right)+3.3236\left(x_{5}\right)\right)},
$$

where $P$ is the probability of a stream flowing perennially at a specific site, $\exp$ is approximately $2.7183, x_{1}$ is the cube root of the drainage area of the basin $\left(\mathrm{mi}^{2}\right), x_{2}$ is the drainage density in the basin $\left(\mathrm{mi} / \mathrm{mi}^{2}\right), x_{3}$ is the square root of the areal percentage of stratified-drift deposits in the basin (percentage), $x_{4}$ is the mean basin slope of the basin (percentage), and $x_{5}$ is an integer variable for the location of the stream site in the South Coastal Basin identifier $(1=$ in the South Coastal Basin, and $0=$ in the remainder of State). Results of the analysis of the maximum estimates of this equation are presented in table 2 (SAS Institute Inc., 1995, p. 20-22). The p-values of each explanatory variable (parameters) are less than 0.05 , the value used as the statistical significance level for entry or retention in the equation. Summary statistics of the logistic regression analyses for this equation with five explanatory variables (parameters) and other selected equations, which were determined to be the best equations of the equations tested with one to four variables, are presented in appendix A.

\section{Application}

An example application of the equation is provided for station NL-29 (table 5 and fig. 2) in the South Coastal Basin. Flow was observed at this stream site on August 20, 1999, and the site is represented as perennial on the USGS topographic map (Cohasset, Mass.). The values of the explanatory variables for input to the logistic regression equation were the cube root of a drainage area of $0.79 \mathrm{mi}^{2}\left(x_{1}\right)$, a drainage density of $2.26 \mathrm{mi} / \mathrm{mi}^{2}\left(x_{2}\right)$, the square root of areal percentage of stratified-drift deposits of 45.61 percent $\left(x_{3}\right)$, and a mean basin slope of 1.47 percent $\left(x_{4}\right)$. The location-integer variable determined from a map was $1\left(x_{5}\right)$, because the stream site is located in the South Coastal Basin. The equation for this stream site, therefore, is:

$$
P=\frac{\exp \left(-5.6325+3.2619(0.79)^{1 / 3}-0.2566(2.26)+0.1248(45.61)^{1 / 2}+0.1929(1.47)+3.3236(1)\right)}{1+\exp \left(-5.6325+3.2619(0.79)^{1 / 3}-0.2566(2.26)+0.1248(45.61)^{1 / 2}+0.1929(1.47)+3.3236(1)\right)}
$$

Table 2. Analysis of maximum likelihood estimates for the logistic regression equation for estimating the probability of a stream flowing perennially in Massachusetts

\begin{tabular}{|c|c|c|c|c|c|}
\hline Explanatory variable & $\begin{array}{l}\text { Degrees of } \\
\text { freedom }\end{array}$ & Estimate & $\begin{array}{l}\text { Standard } \\
\text { error }\end{array}$ & Chi-square & $p$-value \\
\hline Intercept ............. & 1 & -5.6325 & 0.9406 & 35.8614 & $<0.0001$ \\
\hline Drainage $\operatorname{area}^{1 / 3}$ & 1 & 3.2619 & .4829 & 45.6267 & $<.0001$ \\
\hline 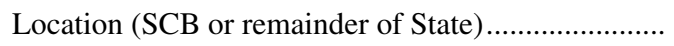 & 1 & 3.3236 & .5381 & 38.1495 & $<.0001$ \\
\hline Mean basin slope & 1 & .1929 & .0636 & 9.1909 & .0024 \\
\hline Areal percentage of stratified-drift deposits ${ }^{1 / 2} \ldots \ldots \ldots . .$. & 1 & .1248 & .0496 & 6.3344 & .0118 \\
\hline 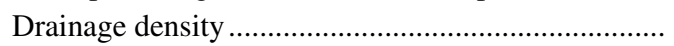 & 1 & -.2566 & .1134 & 5.1242 & .0236 \\
\hline
\end{tabular}

[SAS Institute, Inc., 1995; ${ }^{1 / 3}$, cube root; ${ }^{1 / 2}$, square root; <, actual value less than value shown] 
The resulting probability, $P$, that this stream site is perennial, as determined with the logistic regression equation, is 0.76 (or 76 percent). Probabilities calculated with the logistic regression equation are given for the 173 stream sites in Massachusetts (table 4) and for the 132 sites in the South Coastal Basin (table 5).

The logistic regression equation developed during this study could be used for estimating the probability of a stream flowing perennnial at a specific site at a probability cutpoint of 0.50 , where a stream site would have an equal likelihood of being classified as perennial. The 0.50 cutpoint for this equation would result in about 70 percent of the events (perennial streams) and nonevents (intermittent streams) in the database being correctly classsified (table 3 ). Probability cutpoints other than 0.50 could be used, but the larger the cutpoint used, the greater the likelihood that a stream site will be classified as intermittent (table 3, False Negative column; events or perennial streams are incorrectly classified as nonevents or intermittent streams) and the smaller the cutpoint used, the greater the likelihood that a stream site will be classified as perennial (table 3, False Positive column; nonevents or intermittent streams are incorrectly classified as events or perennial streams).

Table 3. Classification table for the logistic regression equation for estimating the probability of a stream flowing perennially in Massachusetts

[Correct columns provide the frequency with which observations are correctly classified. Incorrect columns provide the frequency with which observations are incorrectly classified. Event is a perennial observation. Nonevent is an intermittent observation. Percent columns-Correct is the probability that the equation correctly classifies the sample data for each probability cutpoint. Sensitivity is the ratio of correctly classified events over the total number of events. For instance, at a cutpoint of 0.50 the sensitivity is 79.5 percent, because 136 of the 171 events are correctly classified. Specificity is the ratio of correctly classified nonevents over the total number of nonevents. For instance, at a cutpoint of 0.50 the specificity is 56.7 percent, because 76 of 134 nonevents are correctly classified. False positive is the ratio of the number of nonevents incorrectly classified as events over the sum of all observations classified as events. For instance, at a cutpoint of 0.50 the 58 nonevents incorrectly classified as events over the sum of 194 events. False negative is the ratio of the number of events incorrectly classified as nonevents over the sum of all observations classified as nonevents. For instance, at a cutpoint of 0.50 the 35 events incorrectly classified as nonevents over the sum of 111 nonevents. SAS Institute, Inc., 1995, p. 45-50]

\begin{tabular}{|c|c|c|c|c|c|c|c|c|c|}
\hline \multirow{2}{*}{$\begin{array}{c}\text { Probability } \\
\text { level }\end{array}$} & \multicolumn{2}{|c|}{ Correct } & \multicolumn{2}{|c|}{ Incorrect } & \multicolumn{5}{|c|}{ Percent } \\
\hline & Event & Nonevent & Event & Nonevent & Correct & Sensitivity & Specificity & $\begin{array}{c}\text { False } \\
\text { positive }\end{array}$ & $\begin{array}{c}\text { False } \\
\text { negative }\end{array}$ \\
\hline 0.00 & 171 & 0 & 134 & 0 & 56.1 & 100.0 & 0.0 & 43.9 & 0.0 \\
\hline .05 & 171 & 8 & 126 & 0 & 58.7 & 100.0 & 6.0 & 42.4 & .0 \\
\hline .10 & 171 & 15 & 119 & 0 & 61.0 & 100.0 & 11.2 & 41.0 & .0 \\
\hline .15 & 168 & 29 & 105 & 3 & 64.6 & 98.2 & 21.6 & 38.5 & 9.4 \\
\hline .20 & 167 & 36 & 98 & 4 & 66.6 & 97.7 & 26.9 & 37.0 & 10.0 \\
\hline .25 & 164 & 41 & 93 & 7 & 67.2 & 95.9 & 30.6 & 36.2 & 14.6 \\
\hline .30 & 162 & 45 & 89 & 9 & 67.9 & 94.7 & 33.6 & 35.5 & 16.7 \\
\hline .35 & 159 & 58 & 76 & 12 & 71.1 & 93.0 & 43.3 & 32.3 & 17.1 \\
\hline .40 & 151 & 65 & 69 & 20 & 70.8 & 88.3 & 48.5 & 31.4 & 23.5 \\
\hline .45 & 141 & 73 & 61 & 30 & 70.2 & 82.5 & 54.5 & 30.2 & 29.1 \\
\hline .50 & 136 & 76 & 58 & 35 & 69.5 & 79.5 & 56.7 & 29.9 & 31.5 \\
\hline .55 & 127 & 86 & 48 & 44 & 69.8 & 74.3 & 64.2 & 27.4 & 33.8 \\
\hline .60 & 112 & 97 & 37 & 59 & 68.5 & 65.5 & 72.4 & 24.8 & 37.8 \\
\hline .65 & 100 & 100 & 34 & 71 & 65.6 & 58.5 & 74.6 & 25.4 & 41.5 \\
\hline .70 & 86 & 108 & 26 & 85 & 63.6 & 50.3 & 80.6 & 23.2 & 44.0 \\
\hline .75 & 68 & 121 & 13 & 103 & 62.0 & 39.8 & 90.3 & 16.0 & 46.0 \\
\hline .80 & 57 & 128 & 6 & 114 & 60.7 & 33.3 & 95.5 & 9.5 & 47.1 \\
\hline .85 & 33 & 130 & 4 & 138 & 53.4 & 19.3 & 97.0 & 10.8 & 51.5 \\
\hline .90 & 23 & 133 & 1 & 148 & 51.1 & 13.5 & 99.3 & 4.2 & 52.7 \\
\hline .95 & 11 & 133 & 1 & 160 & 47.2 & 6.4 & 99.3 & 8.3 & 54.6 \\
\hline 1.00 & 0 & 134 & 0 & 171 & 43.9 & .0 & 100.0 & .0 & 56.1 \\
\hline
\end{tabular}




\section{LIMITATIONS OF THE LOGISTIC REGRESSION EQUATION AND AREAS FOR FURTHER STUDY}

The logistic regression equation developed is applicable for stream sites with drainage areas between 0.02 and $7.00 \mathrm{mi}^{2}$ in the South Coastal Basin and between 0.14 and $8.94 \mathrm{mi}^{2}$ in the remainder of Massachusetts, because these were the smallest and largest drainage areas used in equation development for their respective areas. The equation may not be reliable for drainage areas less than $0.14 \mathrm{mi}^{2}$ in the State and less than $0.02 \mathrm{mi}^{2}$ in the South Coastal Basin. For drainage areas greater than $8.94 \mathrm{mi}^{2}$ in the State and greater than $7.00 \mathrm{mi}^{2}$ in the South Coastal Basin the equation could be used. It may not be necessary, however, because all stream sites greater than $8.04 \mathrm{mi}^{2}$ in the State and $1.92 \mathrm{mi}^{2}$ in the South Coastal Basin were perennial. The equation may not be reliable for losing reaches of streams, such as for streams that flow off an area underlain by till or bedrock onto an area underlain by stratified-drift deposits (these areas are likely more prevalent where hillsides meet river valleys in central and western Massachusetts). At this juncture of the different underlying surficial deposit types, the stream can lose streamflow through its streambed. Generally, a losing stream reach occurs where the water table does not intersect the streambed in the channel (water table is below the streambed) during low-flow periods. In these reaches, the equation would tend to overestimate the probability of a stream flowing perennially at a site.

The logistic regression equation may not be reliable in areas of Massachusetts where ground-water and surface-water drainage areas for a stream site differ. This condition may be present in southeastern Massachusetts, particularly for streams draining the southern part of the South Coastal Basin, the eastern part of the Buzzards Bay Basin, and the entire area of the Cape Cod and Islands Basins (labeled as the Southeast Coastal Region in fig. 1). In these areas, ground water can flow from one basin into another; therefore, in basins that have a larger ground-water contributing area than the surface-water drainage area the equation may underestimate the probability that a stream is perennial. Conversely, in areas where the ground-water contributing area is less than the surfacewater-drainage area, the equation may overestimate the probability that a stream is perennial.

The accuracy of the logistic regression equation is a function of the quality of the data used in its development. This data includes the measured perennial or intermittent status of a stream site, the occurrence of unknown regulation above a site, and the measured basin characteristics. The measured perennial or intermittent status of stream sites in Massachusetts is based on information in the USGS NWIS database. Streamflow measured as less than $0.005 \mathrm{ft}^{3} / \mathrm{s}$ is rounded down to zero, so it is possible that several streamflow measurements reported as zero may have had flows less than $0.005 \mathrm{ft}^{3} / \mathrm{s}$ in the stream. This measurement would cause stream sites to be classified as intermittent when they actually are perennial. Additionally, of the stream sites selected from the NWIS database, 61 of 62 intermittent-stream sites and 89 of 89 perennial-stream sites were represented as perennial streams on USGS topographic maps; therefore, the Statewide database (sample) used in development of the equation may not be random, because stream sites often selected for streamflow measurements are represented as perennial streams on USGS topographic maps. Also, the drainage area of stream sites selected for streamflow measurements generally is greater than about $1.0 \mathrm{mi}^{2}$, which may result in the sample not being random.

The observed perennial or intermittent status of stream sites in the South Coastal Basin database may also be biased, because the sites were measured during the summer of 1999. The summer of 1999 did not meet the definition of an extended drought; but monthly precipitation near the South Coastal Basin was less than 50 percent of average in April, less than 25 percent of average in June, about 75 percent of average in July (excluding one station), and about 50 percent of average in August (excluding one station) (fig. 6). Additionally, Socolow and others (2000) reported streamflows and ground-water levels well below normal throughout most of Massachusetts during the summer of 1999. Consequently, stream sites classified as intermittent would have been omitted from the database had this period been classified as an extended drought. This climatic condition during the summer of 


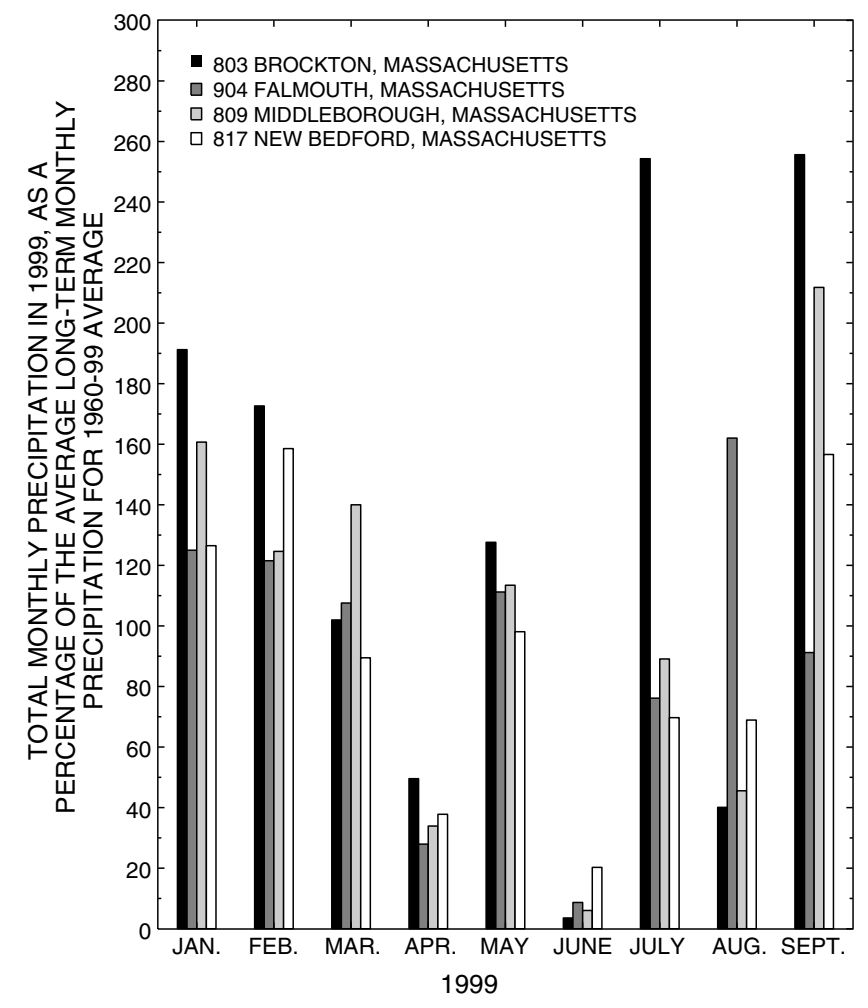

Figure 6. Total monthly precipitation from January through September 1999, as a percentage of the average long-term monthly precipitation for 1960-99 at the Brockton, Falmouth, Middleborough, and New Bedford precipitation stations near the South Coastal Basin, southeastern Massachusetts.

1999 could bias the logistic regression equation toward a lower probability of a stream site being considered perennial in the South Coastal Basin.

Basin characteristics of the stream sites used in the logistic equation development are limited by the accuracy of the digital data layers used. In the future, digital data layers (such as hydrography, surficial geology, soils, DEMs, and land use) will be at lower scales, such as $1: 5,000$ or $1: 25,000$. This would improve the accuracy of the measured basin characteristics used as explanatory variables to predict the probability of a stream flowing perennially. For this study, the area of stratified-drift deposits and consequently the areal percentage of stratified-drift deposits included areas with sand and gravel, large sand, fine-grained, and floodplain alluvium deposits. Future studies would allow more specificity in testing the areal percentage of surficial deposits as explanatory variables. For example, the areal percentage of sand and gravel deposits may be an important explanatory variable for estimating the probability that a stream site is perennial.

The accuracy of the logistic regression equation also may be improved with the testing of additional basin characteristics as explanatory variables. These explanatory variables could include areal percentage of wetlands (forested and non-forested), areal percentage of water bodies, areal percentage of forested land, areal percentage of urban land, or mean, minimum, and maximum basin elevation. Soils data from county soil surveys completed by the Natural Resources Conservation Service (formerly the Soil Conservation Service) eventually will be available for all counties of Massachusetts as a digital data layer referred to as SSURGO (U.S. Department of Agriculture, Natural Resources Conservation Service, Soil Survey Division, 2000). This data layer would allow testing of soil characteristics (such as the four different hydrologic soil groups $\mathrm{A}, \mathrm{B}, \mathrm{C}$, and $\mathrm{D}$, which relate to the infiltration rate of particular soil types) as potential explanatory variables. Physically measured characteristics of the stream at the stream sites also may be reflective of its perennial or intermittent status, such as the width of the stream channel at the mean annual high-water line (bankfull), the stream channel area at bankfull, and general streambed material.

The logistic regression equation for this study or future studies could be incorporated into the STREAMSTATS, so that the probability of a stream flowing perennially at a specific site could be calculated interactively by users on the World Wide Web. The equation also could be used to develop maps depicting intermittent and perennial streams in Massachusetts, if a particular threshold of acceptable probability for classifying a stream as perennial at a site were determined.

\section{SUMMARY AND CONCLUSIONS}

City and town conservation commissions and the Massachusetts Department of Environmental Protection (MADEP) are charged with protecting the riverfront areas of all rivers that flow on a year round basis within Massachusetts, as specified in the Commonwealth of Massachusetts Rivers Protection 
Act of 1996. The 310 Code of Massachusetts Regulations (CMR) 10.58(2)(a) defines the riverfront areas as the $200-\mathrm{ft}$ wide area extending along the length of each side of the stream from the mean annual highwater line on each side of perennial streams, with exceptions in some urban areas. Initial designation of a stream being perennial or intermittent at a site is determined by the representation on the most current USGS topographic map, which may or may not accurately represent a perennial or intermittent status, or on a more recent map developed by the MADEP (if available). The Regulations, however, do allow the reversal of the perennial or intermittent status at a stream site if a competent source can provide specific evidence to the contrary.

To assist city and town conservation commissions and the MADEP in determining whether a stream is perennial or intermittent at a site, a logistic regression equation was developed by the U.S. Geological Survey, in cooperation with the Massachusetts Executive Office of Environmental Affairs (MAEOEA) and the MADEP, for estimating the probability of a stream flowing perennially at a specific site as a function of upstream basin characteristics. Approximately 1,300 stream sites in Massachusetts in the USGS National Water Information System (NWIS) database and 397 stream sites visually inspected in the South Coastal Basin were reviewed for possible inclusion in the database used for equation development. Stream sites had to meet four main requirements to be included in the database. The main requirements for stream sites to be included in the database were that (1) the stream site had to be a natural flowing stream (no regulation by dams, surface-water withdrawals, ground-water withdrawals, diversion, wastewater discharge, and so forth), (2) measured or observed zero flow(s) could not occur during a month of an extended drought, as defined by the Regulations, (3) the perennial-stream sites had to have at least three streamflow measurements to insure that it was likely that at least one measurement was made during normal climatic conditions (only for sites in the NWIS database), and (4) the stream site could not be in the Cape Cod Basin, Islands
Basin, southern part of the South Coastal Basin, or eastern part of the Buzzards Bay Basin (where groundwater and surface-water-source areas differ). The database used to develop the logistic regression equation included 305 stream sites (84 intermittent and 89 perennial sites in the State, and 50 intermittent and 82 perennial sites in the South Coastal Basin). Stream sites used in the database had drainage areas that ranged from 0.14 to $8.94 \mathrm{mi}^{2}$ in the State and from 0.02 to $7.00 \mathrm{mi}^{2}$ in the South Coastal Basin.

The basin characteristics determined for the 305 stream sites were drainage area, drainage density, areal percentage of stratified-drift deposits, and mean basin slope. These basin characteristics, transformations (square, cube, square root, and cube root) of the basin characteristics, a variable that identified whether the stream site was in the western or eastern region of the State, and a variable that identified whether the site was in the South Coastal Basin or in the remainder of the State, then were tested as explanatory variables in the logistic regression analyses. Results of the logistic regression analyses indicate that the probability of a stream flowing perennially at a specific site in Massachusetts can be estimated as a function of (1) drainage area (cube root), (2) drainage density, (3) areal percentage of stratified-drift deposits (square root), (4) mean basin slope, and (5) location of the stream site in the South Coastal Basin or the remainder of the State.

The logistic regression equation developed provides an objective means for estimating the probability of a stream being flowing perennially at a specific site; however, the reliability of the equation is constrained by the data used to develop the equation. The equation may not be reliable for (1) drainage areas less than $0.14 \mathrm{mi}^{2}$ in the State and less than $0.02 \mathrm{mi}^{2}$ in the South Coastal Basin, (2) streams with losing reaches, or (3) streams draining the southern part of the South Coastal Basin and the eastern part of the Buzzards Bay Basin and the entire area of the Cape Cod and Islands Basins. 


\section{REFERENCES CITED}

Collett, D., 1991, Modelling binary data: New York, Chapman and Hall, 369 p.

Eckhardt, D.A.V., Flipse, W.J., and Oaksford, E.T., 1989, Relation between land use and ground-water quality in the upper glacial aquifer in Nassau and Suffolk Counties, Long Island, New York: U.S. Geological Survey Water-Resources Investigations Report 86-4142, 35 p.

Eckhardt, D.A.V., and Stackelberg, P.E., 1995, Relation of ground-water quality to land use on Long Island, New York: Ground Water, v. 33, no. 6, p. 1019-1033.

Helsel, D.R., and Hirsch, R.M., 1992, Statistical methods in water resources: New York, Elsevier Science Publishing Company, Inc., Studies in Environmental Science 49, 522 p.

Hosmer, D.W., and Lemeshow, Stanley, 1989, Applied logistic regression: New York, John Wiley and Sons, $307 \mathrm{p}$.

Kliever, J.D., 1996, Low-flow characteristics of selected streams in northern Rhode Island: U.S. Geological Survey Water-Resources Investigations Report 95-4299, 11 p.

Koltun, G.F., and Sherwood, J.M., 1998, Factors related to the joint probability of flooding on paired streams: U.S. Geological Survey WaterResources Investigations Report 98-4238, 32 p.

Massachusetts Department of Environmental Protection, 2000, Wetlands protection act regulations, 310 CMR 10.00, accessed November 5, 2001, at URL http://www.state.ma.us/dep/brp/ ww/files/310cmr10.pdf.

Ries, K.G., 1994a, Estimation of low-flow duration discharges in Massachusetts: U.S. Geological Survey Water-Supply Paper 2418, 50 p. 1994b, Development and application of generalized-least-squares regression models to estimate low-flow duration discharges in Massachusetts: U.S. Geological Survey WaterResources Investigations Report 94-4155, 33 p.
1997, August median streamflows in Massachusetts: U.S. Geological Survey WaterResources Investigations Report 97-4190, 27 p.

Ries, K.G., and Friesz, P.J., 2000, Methods for estimating low-flow statistics for Massachusetts streams: U.S. Geological Survey Water-Resources Investigations Report 00-4135, 81 p.

Ries, K.G., Steeves, P.A., Freeman, Aleda, and Singh, Raj, 2000, Obtaining streamflow statistics for Massachusetts streams on the World Wide Web: U.S. Geological Survey Fact Sheet 104-00, 4 p.

SAS Institute, Inc., 1989, SAS/STAT User's guide, version 6 , fourth edition, volume 2 : Cary, N.C., $846 \mathrm{p}$

1995, Logistic regression examples using the SAS system, version 6 (1st ed.): Cary, N.C., 163 p.

Socolow, R.S., Zanca, J.L., Murino, Domenic, Jr., and Ramsbey, L.R., 2000, Water resources data Massachusetts and Rhode Island, water year 1999: U.S. Geological Survey Water Data Report MA-RI-99-1, 401 p. Available online at http://ma.water.usgs.gov/current_cond/adr/adr99/ default.htm.

Squillace, P.J., Moran, M.J., Lapham, W.W., Price, C.V., Clawges, R.M., and Zogorski, J.S., 1999, Volatile organic compounds in untreated ambient groundwater of the United States, 1985-1995: Environmental Science and Technology, v. 33, no. 23 , p. $4176-4187$.

The Commonwealth of Massachusetts, 1996, An act providing protection for the rivers of the Commonwealth, accessed November 5, 2001, at URL http://www.state.ma.us/dep/brp/ww/ files/riveract.htm.

U.S. Department of Agriculture, Natural Resources Conservation Service, Soil Survey Division, 2000, National SSURGO database-data, accessed December 23, 2000, at URL http://www.ftw.nrcs.usda.gov/ssur_data.html. 



\section{Tables 4 and 5}



Table 4. Description, basin characteristics, and perennial- or intermittent-status determination for stream sites at discontinued and continuous streamflow-gaging stations and partial-record stations by region and major river basin in Massachusetts used in development of the logistic regression equation for estimating the probability of a stream flowing perennially in Massachusetts

[USGS Station No.: Location shown in figure 1. Latitude and longitude: Given in degrees, minutes, seconds. I, Intermittent; P, Perennial; USGS, U.S. Geological Survey; mi/mi²; miles per square mile; $\mathrm{mi}^{2}$, square mile; \%, percent]

\begin{tabular}{|c|c|c|c|c|c|c|c|c|c|c|}
\hline $\begin{array}{l}\text { USGS } \\
\text { station } \\
\text { No. }\end{array}$ & Station name & $\begin{array}{c}\text { Latitude } \\
0,11\end{array}$ & $\begin{array}{c}\text { Longitude } \\
\qquad, 11\end{array}$ & $\begin{array}{c}\text { Drainage } \\
\text { area } \\
\left(\mathrm{mi}^{2}\right)\end{array}$ & $\begin{array}{c}\text { Drainage } \\
\text { density } \\
\left(\mathrm{mi}^{2} / \mathrm{mi}^{2}\right)\end{array}$ & $\begin{array}{l}\text { Area of } \\
\text { stratified- } \\
\text { drift } \\
\text { deposits } \\
(\%)\end{array}$ & $\begin{array}{c}\text { Mean } \\
\text { basin } \\
\text { slope } \\
(\%)\end{array}$ & $\begin{array}{l}\text { Measured or } \\
\text { recorded } \\
\text { status of } \\
\text { stream site }\end{array}$ & $\begin{array}{c}\text { USGS } \\
\text { topographic } \\
\text { map designation } \\
\text { of status of } \\
\text { stream site }\end{array}$ & $\begin{array}{l}\text { Probability } \\
\text { of stream } \\
\text { flowing } \\
\text { perennially at } \\
\text { stream site } \\
\text { (\%) }\end{array}$ \\
\hline \multicolumn{11}{|c|}{ EASTERN REGION } \\
\hline \multicolumn{11}{|c|}{ North Coastal Basin } \\
\hline 01073860 & Small Pox Brook at Salisbury & 425100 & 705159 & 1.83 & 2.30 & 98.36 & 0.84 & I & $\mathrm{P}$ & 30 \\
\hline 01102053 & Crane Brook at Danvers & 423334 & 705655 & 2.72 & 1.79 & 63.24 & 1.99 & $\mathrm{P}$ & $\mathrm{P}$ & 46 \\
\hline \multicolumn{11}{|c|}{ Nashua River Basin } \\
\hline 01094760 & Waushacum Brook near West Boylston & 422349 & 714648 & 7.41 & 1.72 & 21.86 & 3.81 & $\mathrm{P}$ & $\mathrm{P}$ & 83 \\
\hline 01095380 & Trout Brook near Holden & 422300 & 715012 & 6.79 & 1.71 & 28.72 & 3.99 & $\mathrm{P}$ & $\mathrm{P}$ & 82 \\
\hline 01095928 & Trapfall Brook near Ashby & 424024 & 714639 & 5.89 & 2.25 & 11.21 & 4.93 & I & $\mathrm{P}$ & 74 \\
\hline 01095940 & Locke Brook at West Townsend & 424042 & 714531 & 4.26 & 2.19 & 12.57 & 5.96 & I & $\mathrm{P}$ & 66 \\
\hline 01095960 & Walker Brook near West Townsend & 424207 & 714606 & 7.03 & 1.67 & 2.23 & 6.37 & I & $\mathrm{P}$ & 83 \\
\hline 01095989 & Bixby Brook near Townsend & 423853 & 714118 & 2.76 & 1.77 & 57.21 & 3.61 & I & $\mathrm{P}$ & 53 \\
\hline 01096504 & Reedy Meadow Brook at East Pepperell & 424003 & 713355 & 1.92 & 1.70 & 79.17 & 1.93 & $\mathrm{P}$ & $\mathrm{P}$ & 37 \\
\hline 01096505 & Unkety Brook near Pepperell & 424123 & 713254 & 6.84 & 1.86 & 67.54 & 2.28 & $\mathrm{P}$ & $\mathrm{P}$ & 82 \\
\hline \multicolumn{11}{|c|}{ Concord River Basin } \\
\hline 01096600 & Assabet River at Westborough & 421616 & 713759 & 6.73 & 2.36 & 23.72 & 3.63 & I & $\mathrm{P}$ & 77 \\
\hline 01096850 & Mill Brook near Hudson & 422459 & 713509 & 4.61 & 2.75 & 29.51 & 3.47 & I & $\mathrm{P}$ & 61 \\
\hline 01096855 & Danforth Brook at Hudson & 422357 & 713400 & 6.62 & 2.80 & 26.59 & 3.71 & $\mathrm{P}$ & $\mathrm{P}$ & 76 \\
\hline 01096906 & Boulder Brook near East Bolton & 422710 & 713452 & 1.36 & 2.08 & 2.25 & 3.91 & I & $\mathrm{P}$ & 17 \\
\hline 01096910 & Boulder Brook at East Bolton & 422704 & 713439 & 1.61 & 1.86 & 11.18 & 3.66 & $\mathrm{P}$ & $\mathrm{P}$ & 24 \\
\hline 01097200 & Heath Hen Meadow Brook at Stow & 422644 & 713002 & 3.91 & 2.86 & 22.98 & 1.97 & I & $\mathrm{P}$ & 44 \\
\hline \multicolumn{11}{|c|}{ Merrimack River Basin } \\
\hline 01100050 & Trout Brook near Dracut & 424108 & 711610 & .69 & 4.61 & 2.90 & 2.45 & I & $\mathrm{P}$ & 4 \\
\hline 01100100 & Richardson Brook near Lowell & 423948 & 711602 & 4.23 & 2.99 & 25.42 & 1.96 & I & $\mathrm{P}$ & 47 \\
\hline 01100200 & Trull Brook near Lowell & 423858 & 711538 & 4.33 & 1.94 & 71.56 & 1.36 & I & $\mathrm{P}$ & 62 \\
\hline 01100300 & Fish Brook near Andover & 424047 & 711308 & 5.87 & 2.22 & 48.44 & 2.37 & I & $\mathrm{P}$ & 73 \\
\hline 01100350 & Bartlett Brook near Dracut & 424208 & 711516 & 1.72 & 2.67 & 16.86 & 2.14 & I & $\mathrm{P}$ & 18 \\
\hline
\end{tabular}


Table 4. Description, basin characteristics, and perennial- or intermittent-status determination for stream sites at discontinued and continuous streamflow-gaging stations and partial-record stations by region and major river basin in Massachusetts used in development of the logistic regression equation for estimating the probability of a stream flowing perennially in Massachusetts - Continued

\begin{tabular}{|c|c|c|c|c|c|c|c|c|c|c|}
\hline $\begin{array}{l}\text { USGS } \\
\text { station } \\
\text { No. }\end{array}$ & Station name & $\begin{array}{c}\text { Latitude } \\
\circ, 1,\end{array}$ & 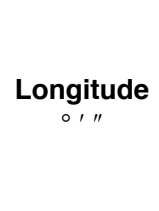 & $\begin{array}{c}\text { Drainage } \\
\text { area } \\
\left(\mathbf{m i}^{2}\right)\end{array}$ & $\begin{array}{c}\text { Drainage } \\
\text { density } \\
\left(\mathrm{mi}^{2} / \mathrm{mi}^{2}\right)\end{array}$ & $\begin{array}{l}\text { Area of } \\
\text { stratified- } \\
\text { drift } \\
\text { deposits } \\
(\%)\end{array}$ & $\begin{array}{c}\text { Mean } \\
\text { basin } \\
\text { slope } \\
(\%)\end{array}$ & $\begin{array}{l}\text { Measured or } \\
\text { recorded } \\
\text { status of } \\
\text { stream site }\end{array}$ & $\begin{array}{c}\text { USGS } \\
\text { topographic } \\
\text { map designation } \\
\text { of status of } \\
\text { stream site }\end{array}$ & $\begin{array}{c}\text { Probability } \\
\text { of stream } \\
\text { flowing } \\
\text { perennially at } \\
\text { stream site } \\
(\%)\end{array}$ \\
\hline
\end{tabular}

EASTERN REGION-Continued

01100400 Bartlett Brook near Methuen

01100640 Bare Meadow Brook near Methuen

01100650 Hawkes Brook at North Street near Methuen

01100655 Hawkes Brook near Methuen

01100665 West Meadow Brook near Haverhill

01100700 East Meadow River near Haverhill

01100800 Cobbler Brook near Merrimac

01100802 Cobbler Brook at East Main Street at Merrimac

01100808 Sawmill Brook at West Newbury

01100810 Indian River near West Newbury

01100817 Upper Artichoke Reservoir Tributary near West Newbury

01100572 Elm Brook Tributary near Concord

01100593 McKee Brook near Billerica

01100607 Meadow Brook at Kendall Street near Tewksbury

01100608 Meadow Brook near Tewksbury

01100616 Shawsheen River Tributary \#3 at Ballardvale

01100617 Shawsheen River Tributary \#5 near Andover

01100618 Shawsheen River Tributary \#6 near Andover

01100623 Rogers Brook Tributary at Andover

01100628 Hussey Brook near Andover

01100633 Shawsheen River Tributary \#8 near North Andover

01101850 Pye Brook near Topsfield

Merrimack River Basin-Continued

$\begin{array}{lllllll}424215 & 711327 & 6.68 & 2.89 & 11.67 & 2.17 & \text { I }\end{array}$

$\begin{array}{llllll}424438 & 710859 & 80 & 1.90 & 32.50 & 1.94\end{array}$

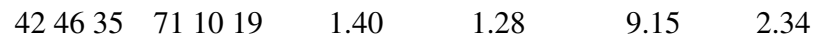

$\begin{array}{llllll}424506 & 710817 & 4.35 & 1.99 & 17.72 & 2.57\end{array}$

$\begin{array}{lllll}424700 \quad 710741 & 1.42 & 1.30 & .00 & 2.69\end{array}$

$\begin{array}{llllll}424841 & 710159 & 5.54 & 1.82 & 31.05 & 2.78\end{array}$

$425055 \quad 710110-77 \quad 2.87$

$\begin{array}{lllll}425003 & 710005 & 2.48 & 2.41 & 12.50\end{array}$

$\begin{array}{llllll}424753 & 705845 & .51 & 1.75 & 13.73 & 2.85\end{array}$

$\begin{array}{llllll}424825 & 705804 & 1.41 & 1.80 & 11.27 & 3.37\end{array}$

$30.60 \quad 2.61$

\section{Shawsheen River Basin}

\begin{tabular}{|c|c|c|c|c|c|c|c|c|}
\hline 422806 & 711905 & .14 & 2.14 & 100.00 & .14 & I & $\mathrm{P}$ & 4 \\
\hline 423129 & 711447 & .29 & 1.86 & 13.79 & .70 & I & $\mathrm{P}$ & 3 \\
\hline 423756 & 711315 & 1.46 & 3.10 & 18.69 & 2.00 & I & $\mathrm{P}$ & 14 \\
\hline 423714 & 711244 & 4.09 & 2.50 & 53.06 & 1.37 & $\mathrm{P}$ & $\mathrm{P}$ & 53 \\
\hline 423732 & 710827 & .76 & 2.57 & 31.58 & 3.15 & I & I & 12 \\
\hline 423731 & 710958 & .38 & 1.50 & 44.74 & 2.11 & I & $\mathrm{P}$ & 8 \\
\hline 423825 & 710845 & .14 & 5.14 & 7.14 & 3.18 & I & I & 1 \\
\hline 423930 & 710735 & .14 & 1.40 & .00 & 2.09 & I & I & 2 \\
\hline 424001 & 711023 & .38 & 3.11 & 28.95 & 1.75 & I & $\mathrm{P}$ & 4 \\
\hline 424049 & 710802 & .27 & .96 & .00 & 4.13 & I & I & 5 \\
\hline
\end{tabular}

Ispwich River Basin

1.12

$\mathrm{P}$

$\mathrm{P}$

77 
Table 4. Description, basin characteristics, and perennial- or intermittent-status determination for stream sites at discontinued and continuous streamflow-gaging stations and partial-record stations by region and major river basin in Massachusetts used in development of the logistic regression equation for estimating the probability of a stream flowing perennially in Massachusetts - Continued

\begin{tabular}{|c|c|c|c|c|c|c|c|c|c|c|}
\hline $\begin{array}{c}\text { USGS } \\
\text { station } \\
\text { No. }\end{array}$ & Station name & $\begin{array}{l}\text { Latitude } \\
0,1,\end{array}$ & $\underset{0,11}{\text { Longitude }}$ & $\begin{array}{l}\text { Drainage } \\
\text { area } \\
\left(\mathbf{m i}^{2}\right)\end{array}$ & $\begin{array}{c}\text { Drainage } \\
\text { density } \\
\left(\mathrm{mi} / \mathrm{mi}^{2}\right)\end{array}$ & $\begin{array}{l}\text { Area of } \\
\text { stratified- } \\
\text { drift } \\
\text { deposits } \\
(\%)\end{array}$ & $\begin{array}{c}\text { Mean } \\
\text { basin } \\
\text { slope } \\
(\%)\end{array}$ & $\begin{array}{l}\text { Measured or } \\
\text { recorded } \\
\text { status of } \\
\text { stream site }\end{array}$ & $\begin{array}{c}\text { USGS } \\
\text { topographic } \\
\text { map designation } \\
\text { of status of } \\
\text { stream site }\end{array}$ & $\begin{array}{l}\text { Probability } \\
\text { of stream } \\
\text { flowing } \\
\text { perennially at } \\
\text { stream site } \\
(\%)\end{array}$ \\
\hline \multicolumn{11}{|c|}{ EASTERN REGION-Continued } \\
\hline \multicolumn{11}{|c|}{ Boston Harbor Basin } \\
\hline 011024592 & Aberjona River Tributary \#1 near Woburn & 422948 & 710750 & 5.76 & 1.73 & 26.41 & 1.52 & I & $\mathrm{P}$ & 67 \\
\hline 011024596 & Aberjona River Tributary \#3 near Woburn & 422936 & 710744 & 6.17 & 1.83 & 65.56 & 1.57 & I & $\mathrm{P}$ & 77 \\
\hline 01102470 & Sweetwater Brook at Stoneham & 422845 & 710644 & 2.08 & .26 & 15.38 & 2.41 & $\mathrm{P}$ & $\mathrm{P}$ & 36 \\
\hline 01102482 & Little Brook near Woburn & 422848 & 711101 & 1.04 & 2.59 & 2.88 & 2.63 & I & $\mathrm{P}$ & 9 \\
\hline 01102490 & Shaker Glen Brook near Woburn & 422816 & 711034 & 3.05 & 1.66 & 11.15 & 3.21 & $\mathrm{P}$ & $\mathrm{P}$ & 43 \\
\hline 01103015 & Mill Brook at Arlington & 422520 & 710859 & 5.35 & 1.96 & 42.24 & 3.21 & $\mathrm{P}$ & $\mathrm{P}$ & 73 \\
\hline 01104880 & Neponset River Tributary near Walpole & 420955 & 711454 & 1.53 & 2.93 & 20.45 & 1.66 & I & $\mathrm{P}$ & 15 \\
\hline 01104910 & Bubbling Brook North Street near Westwood & 421204 & 711501 & .19 & .85 & .00 & 3.90 & I & $\mathrm{P}$ & 4 \\
\hline 01104960 & Germany Brook near Norwood & 421104 & 711329 & 2.37 & 1.76 & 28.27 & 1.65 & $\mathrm{P}$ & $\mathrm{P}$ & 32 \\
\hline 01104980 & Hawes Brook at Norwood & 421026 & 711231 & 8.64 & 1.79 & 25.46 & 2.27 & $\mathrm{P}$ & $\mathrm{P}$ & 84 \\
\hline 01105100 & Traphole Brook near Norwood & 420936 & 711147 & 3.40 & 1.72 & 57.65 & 3.03 & $\mathrm{P}$ & $\mathrm{P}$ & 59 \\
\hline 01105150 & Neponset River Tributary \#2 near Sharon & 420852 & 711048 & .39 & 3.02 & 54.96 & 4.38 & I & $\mathrm{P}$ & 10 \\
\hline 01105400 & Pequid Brook near Canton & 421029 & 710645 & 4.52 & 1.74 & 39.08 & .92 & I & $\mathrm{P}$ & 57 \\
\hline 01105525 & Purgatory Brook at Islington & 421254 & 711124 & 1.28 & 2.66 & 5.09 & 1.96 & I & $\mathrm{P}$ & 11 \\
\hline 01105568 & Cochato River at Holbrook & 420919 & 710137 & 4.31 & 1.52 & 47.33 & 1.30 & $\mathrm{P}$ & $\mathrm{P}$ & 60 \\
\hline 01105573 & Tumbling Brook at Holbrook & 420959 & 710113 & 1.00 & 1.85 & 19.65 & 1.38 & I & $\mathrm{P}$ & 12 \\
\hline 01105575 & Cranberry Brook at Braintree Highlands & 421102 & 710042 & 1.72 & 1.04 & .58 & 2.13 & $\mathrm{P}$ & $\mathrm{P}$ & 18 \\
\hline 01105600 & Old Swamp River near South Weymouth & 421125 & 705643 & 4.47 & 1.80 & 33.56 & 1.27 & $\mathrm{P}$ & $\mathrm{P}$ & 56 \\
\hline 01105614 & $\begin{array}{l}\text { Whitmans Pond Outlet Tributary \#2 at East } \\
\text { Weymouth }\end{array}$ & 421252 & 705508 & .33 & .91 & 94.93 & 1.82 & I & I & 12 \\
\hline 01105630 & $\begin{array}{l}\text { Crooked Meadow River near Hingham } \\
\text { Center }\end{array}$ & 421253 & 705306 & 4.91 & 2.22 & 74.13 & 1.63 & $\mathrm{P}$ & $\mathrm{P}$ & 68 \\
\hline \multicolumn{11}{|c|}{ Charles River Basin } \\
\hline 01103214 & Beaver Brook near Holliston & 421048 & 712846 & 2.24 & 2.93 & 27.03 & 2.46 & I & $\mathrm{P}$ & 27 \\
\hline 01103253 & Chicken Brook near West Medway & 420827 & 712526 & 7.23 & 2.55 & 15.08 & 2.29 & $\mathrm{P}$ & $\mathrm{P}$ & 72 \\
\hline 01103360 & Mill Brook near Medfield & 421238 & 711848 & 2.14 & 2.48 & 31.41 & 3.01 & I & $\mathrm{P}$ & 31 \\
\hline 01103415 & Indian Brook near Sherborn & 421534 & 712125 & 1.30 & 1.97 & 52.31 & 1.90 & I & $\mathrm{P}$ & 21 \\
\hline 01103440 & Fuller Brook at Wellesley & 421745 & 711718 & 3.91 & 1.80 & 60.10 & 1.58 & $\mathrm{P}$ & $\mathrm{P}$ & 58 \\
\hline 01104400 & Hobbs Brook near Lincoln & 422617 & 711651 & 1.30 & 2.52 & 45.44 & 2.56 & I & $\mathrm{P}$ & 20 \\
\hline 01104405 & Hobbs Brook at Mill Street near Lincoln & 422611 & 711612 & 2.04 & 2.50 & 42.13 & 2.34 & I & $\mathrm{P}$ & 29 \\
\hline
\end{tabular}


Table 4. Description, basin characteristics, and perennial- or intermittent-status determination for stream sites at discontinued and continuous streamflow-gaging stations and partial-record stations by region and major river basin in Massachusetts used in development of the logistic regression equation for estimating the probability of a stream flowing perennially in Massachusetts - Continued

\begin{tabular}{|c|c|c|c|c|c|c|c|c|c|c|}
\hline $\begin{array}{l}\text { USGS } \\
\text { station } \\
\text { No. }\end{array}$ & Station name & $\begin{array}{c}\text { Latitude } \\
0,1,\end{array}$ & Longitude & $\begin{array}{c}\text { Drainage } \\
\text { area } \\
\left(\mathbf{m i}^{2}\right)\end{array}$ & $\begin{array}{c}\text { Drainage } \\
\text { density } \\
\left(\mathrm{mi} / \mathrm{mi}^{2}\right)\end{array}$ & $\begin{array}{l}\text { Area of } \\
\text { stratified- } \\
\text { drift } \\
\text { deposits } \\
(\%)\end{array}$ & $\begin{array}{c}\text { Mean } \\
\text { basin } \\
\text { slope } \\
(\%)\end{array}$ & $\begin{array}{l}\text { Measured or } \\
\text { recorded } \\
\text { status of } \\
\text { stream site }\end{array}$ & $\begin{array}{c}\text { USGS } \\
\text { topographic } \\
\text { map designation } \\
\text { of status of } \\
\text { stream site }\end{array}$ & $\begin{array}{l}\text { Probability } \\
\text { of stream } \\
\text { flowing } \\
\text { perennially at } \\
\text { stream site } \\
(\%)\end{array}$ \\
\hline
\end{tabular}

\section{EASTERN REGION-Continued}

01105670 Satuit River at Scituate

01105820 Second Herring Brook at Norwell

01105830 First Herring Brook near Scituate Center

01105861 Jones River Brook near Kingston

011059106 Massttapoisett River Tributary \#1 near Rochester

01105930 Paskamanset River at Turner Pond near New Bedford

01105935 Destruction Brook near South Dartmouth

01105937 Shingle Island River near North Dartmouth

01106000 Adamsville Brook at Adamsville, R.I.

01106430 Trout Brook at Brockton

01106460 Beaver Brook near East Bridgewater

01107000 Dorchester Brook near Brockton

01107010 Queset Brook at North Easton

01108140 Poquoy Brook near North Middleboro

01108180 Cotley River at East Taunton

01108350 Mulberry Meadow Brook near Easton Center

01108600 Hodges Brook at West Mansfield

01109090 Rattlesnake Brook near Assonet

01109185 East Branch Palmer River near Rehoboth 01109200 West Branch Palmer River near Rehoboth

01109225 Rocky Run near Rehoboth

01109381 Speedway Brook at Attleboro
South Coastal Basin

$\begin{array}{rrrrrrl}421135 & 704344 & 1.61 & 1.53 & 9.32 & 0.81 & \mathrm{P} \\ 420936 & 704720 & 3.17 & 1.92 & 24.29 & 1.14 & \mathrm{P} \\ 421130 & 704649 & 1.72 & 1.85 & 4.65 & .61 & \mathrm{P}\end{array}$

$415947 \quad 704718 \quad 4.74 \quad 1.67$

89.03

1.06

\section{Buzzards Bay Basin}

$\begin{array}{lllll}414435 & 705204 & 2.58 & 1.34 & 63.57\end{array}$

$414043 \quad 705839 \quad 8.09$

2.15

44.87

$413420 \quad 710047$

414055710105

2.64

2.18

54.55

$8.59 \quad 1.78$

38.07

2.25

Taunton River Basin

$\begin{array}{llll}420526 & 710045 & 5.88 & 1.70\end{array}$

$420243 \quad 705817 \quad 8.94$

$420341 \quad 710359$

$\begin{array}{llll}420357 \quad 710543 & 7.47 & 2.04\end{array}$

40.48

36.91

18.68

85.12

$\begin{array}{lllll}415257 & 710254 & 7.48 & 1.54 & 49.33\end{array}$

$420107 \quad 710735$

$415911 \quad 711427$

414636710523

8.35

41.92

65.01

35.78

Narragansett Bay and Mt. Hope Bay Shore Basin

$\begin{array}{lllll}415136 & 711347 & 5.86 & 1.48 & 45.90\end{array}$

$\begin{array}{lllll}415246 & 711518 & 4.33 & 2.14 & 64.20\end{array}$

$\begin{array}{lllll}414632 & 71 & 1503 & 7.21 & 1.61\end{array} 39.53$

Tenmile River Basin

$\begin{array}{lllll}415537 & 71 & 1708 & 2.82 & 7.02\end{array}$

.28
16

38

14

69

40

81

40

84

69

72

84

52

76

86

80

77

48

59

71

55

78

17 
Table 4. Description, basin characteristics, and perennial- or intermittent-status determination for stream sites at discontinued and continuous streamflow-gaging stations and partial-record stations by region and major river basin in Massachusetts used in development of the logistic regression equation for estimating the probability of a stream flowing perennially in Massachusetts - Continued

\begin{tabular}{|c|c|c|c|c|c|c|c|c|c|c|}
\hline $\begin{array}{l}\text { USGS } \\
\text { station } \\
\text { No. }\end{array}$ & Station name & $\underset{\circ, 1 "}{\text { Latitude }}$ & 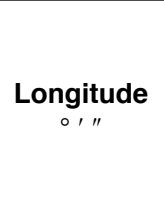 & $\begin{array}{c}\text { Drainage } \\
\text { area } \\
\left(\mathrm{mi}^{2}\right)\end{array}$ & $\begin{array}{c}\text { Drainage } \\
\text { density } \\
\left(\mathrm{mi} / \mathrm{mi}^{2}\right)\end{array}$ & $\begin{array}{l}\text { Area of } \\
\text { stratified- } \\
\text { drift } \\
\text { deposits } \\
(\%)\end{array}$ & $\begin{array}{c}\text { Mean } \\
\text { basin } \\
\text { slope } \\
(\%)\end{array}$ & $\begin{array}{l}\text { Measured or } \\
\text { recorded } \\
\text { status of } \\
\text { stream site }\end{array}$ & $\begin{array}{c}\text { USGS } \\
\text { topographic } \\
\text { map designation } \\
\text { of status of } \\
\text { stream site }\end{array}$ & $\begin{array}{c}\text { Probability } \\
\text { of stream } \\
\text { flowing } \\
\text { perennially at } \\
\text { stream site } \\
(\%)\end{array}$ \\
\hline \multicolumn{11}{|c|}{ EASTERN REGION_Continued } \\
\hline \multicolumn{11}{|c|}{ Blackstone River Basin } \\
\hline 01109950 & West Brook near Shrewsbury & 421729 & 714423 & 2.23 & 2.66 & 23.33 & 4.96 & I & $\mathrm{P}$ & 38 \\
\hline 01111142 & Miscoe Brook near Grafton & 421125 & 713923 & 5.67 & 2.06 & 22.93 & 3.98 & $\mathrm{P}$ & $\mathrm{P}$ & 73 \\
\hline 01111160 & Center Brook at Upton & 421113 & 713546 & 2.10 & 2.66 & 22.89 & 4.90 & I & $\mathrm{P}$ & 34 \\
\hline 01111225 & Emerson Brook near Uxbridge & 420240 & 713721 & 7.26 & 2.37 & 35.81 & 3.15 & $\mathrm{P}$ & $\mathrm{P}$ & 81 \\
\hline 01112190 & Muddy Brook at South Milford & 420535 & 713111 & 6.17 & 2.63 & 15.40 & 3.38 & $\mathrm{P}$ & $\mathrm{P}$ & 69 \\
\hline \multicolumn{11}{|c|}{ Quinebaug River Basin } \\
\hline 01123100 & Mountain Brook near Brimfield & 420710 & 721308 & 1.35 & 3.04 & 14.35 & 8.26 & I & $\mathrm{P}$ & 32 \\
\hline 01123161 & Wales Brook at Brimfield & 420652 & 721136 & 6.57 & 2.33 & 28.61 & 5.96 & I & $\mathrm{P}$ & 84 \\
\hline 01123200 & Stevens Brook at Holland & 420341 & 720945 & 4.39 & 2.95 & 4.10 & 4.63 & $\mathrm{P}$ & $\mathrm{P}$ & 52 \\
\hline 01124100 & Tufts Branch near Dudley & 420142 & 715619 & 2.40 & 3.55 & 4.98 & 4.83 & I & $\mathrm{P}$ & 28 \\
\hline \multicolumn{11}{|c|}{ French River Basin } \\
\hline 01124390 & Little River at Richardson Road Corners & 420916 & 715447 & 8.58 & 3.32 & .12 & 3.82 & $\mathrm{P}$ & $\mathrm{P}$ & 73 \\
\hline 01124750 & Browns Brook near Webster & 420324 & 714951 & .52 & 2.52 & .00 & 4.77 & I & $\mathrm{P}$ & 6 \\
\hline 01124800 & Sucker Brook near Webster & 420401 & 715116 & 1.55 & 5.83 & 2.05 & 6.21 & $\mathrm{I}$ & $\mathrm{P}$ & 12 \\
\hline \multicolumn{11}{|c|}{ WESTERN REGION } \\
\hline \multicolumn{11}{|c|}{ Millers River Basin } \\
\hline 01163298 & Trout Brook near Baldwinville & 423549 & 720528 & 7.22 & 1.51 & 35.87 & 3.09 & $\mathrm{P}$ & $\mathrm{P}$ & 84 \\
\hline 01165250 & Riceville Brook near South Athol & 423217 & 721451 & 7.08 & 1.59 & 20.48 & 4.34 & $\mathrm{P}$ & $\mathrm{P}$ & 84 \\
\hline 01166105 & $\begin{array}{l}\text { Whetstone Brook at Depot Road at Wendell } \\
\text { Depot }\end{array}$ & 423539 & 722141 & 5.24 & 2.02 & 23.66 & 7.39 & $\mathrm{P}$ & $\mathrm{P}$ & 82 \\
\hline 01166400 & Keyup Brook at Erving & 423608 & 722400 & 7.03 & 1.08 & 4.13 & 11.38 & $\mathrm{P}$ & $\mathrm{P}$ & 94 \\
\hline \multicolumn{11}{|c|}{ Deerfield River Basin } \\
\hline 01169800 & Poland Brook near Conway & 422916 & 724447 & 4.02 & 2.04 & 1.17 & 7.01 & $\mathrm{P}$ & $\mathrm{P}$ & 63 \\
\hline 01170240 & Mill Brook near Bernardston & 423933 & 723418 & 2.79 & 1.64 & .00 & 11.40 & $\mathrm{P}$ & $\mathrm{P}$ & 68 \\
\hline
\end{tabular}


Table 4. Description, basin characteristics, and perennial- or intermittent-status determination for stream sites at discontinued and continuous streamflow-gaging stations and partial-record stations by region and major river basin in Massachusetts used in development of the logistic regression equation for estimating the probability of a stream flowing perennially in Massachusetts - Continued

\begin{tabular}{|c|c|c|c|c|c|c|c|c|c|c|}
\hline $\begin{array}{l}\text { USGS } \\
\text { station } \\
\text { No. }\end{array}$ & Station name & $\begin{array}{c}\text { Latitude } \\
0,1,\end{array}$ & $\begin{array}{c}\text { Longitude } \\
0,11\end{array}$ & $\begin{array}{c}\text { Drainage } \\
\text { area } \\
\left(\mathbf{m i}^{2}\right)\end{array}$ & $\begin{array}{c}\text { Drainage } \\
\text { density } \\
\left(\mathrm{mi} / \mathrm{mi}^{2}\right)\end{array}$ & $\begin{array}{l}\text { Area of } \\
\text { stratified- } \\
\text { drift } \\
\text { deposits } \\
(\%)\end{array}$ & $\begin{array}{c}\text { Mean } \\
\text { basin } \\
\text { slope } \\
(\%)\end{array}$ & $\begin{array}{l}\text { Measured or } \\
\text { recorded } \\
\text { status of } \\
\text { stream site }\end{array}$ & $\begin{array}{c}\text { USGS } \\
\text { topographic } \\
\text { map designation } \\
\text { of status of } \\
\text { stream site }\end{array}$ & $\begin{array}{c}\text { Probability } \\
\text { of stream } \\
\text { flowing } \\
\text { perennially at } \\
\text { stream site } \\
\text { (\%) }\end{array}$ \\
\hline
\end{tabular}

\section{WESTERN REGION-Continued}

01170902 Bloody Brook near South Deerfield

01171800 Bassett Brook near Northampton

01177360 South Branch Mill River at Porter Road near East Longmeadow

01184200 Still Brook near West Agawam

01184282 Watchaug Brook near East Longmeadow

01172100 West Wachusett Brook near Princeton

01172900 Potash Brook near Barre

01173100 Galloway Brook near Barre

01173150 Smith Brook near South Barre

01173230 Pine Hill Brook at Barre Plains

01173260 Moose Brook near Barre

01173300 Winimusset Brook at Wheelwright

01173400 Muddy Brook near Hardwick

01173450 Flat Brook near Ware

01174000 Hop Brook near New Salem

01174050 East Branch Fever Brook near Petersham

01174900 Cadwell Creek near Belchertown

01175660 Sevenmile River at State Highway 31 near Spencer

01175670 Sevenmile River near Spencer

01175700 Maynard Brook near Oakham

01175730 Great Brook near East Brookfield

01175760 Trout Brook near Brookfield

01175790 Coys Brook at West Brookfield

01175890 Naultaug Brook near Warren

01175910 Cheney Brook at Warren

\section{Connecticut River Basin}

$\begin{array}{llll}422830 & 723803 & 5.48 & 2.06\end{array}$

$421809 \quad 724116 \quad 5.56 \quad 1.65$

$420506 \quad 722850$

420231724100

6.92

\subsection{4}

36.69

66.04

2.98

5.20

56.93

64.78

2.79

$2.80 \quad 2.34$

Chicopee River Basin

\begin{tabular}{|c|c|c|c|c|c|c|c|c|}
\hline 422847 & 715528 & 1.83 & 1.53 & .00 & 6.98 & I & $\mathrm{P}$ & 33 \\
\hline 422416 & 720241 & .54 & 2.51 & 1.07 & 4.42 & I & $\mathrm{P}$ & 7 \\
\hline 422429 & 720556 & 1.77 & 1.60 & .20 & 3.55 & I & $\mathrm{P}$ & 20 \\
\hline 422352 & 720617 & .77 & 1.31 & .46 & 3.92 & I & $\mathrm{P}$ & 11 \\
\hline 422216 & 720739 & 2.46 & 1.87 & .33 & 5.12 & I & $\mathrm{P}$ & 34 \\
\hline 422352 & 720851 & 4.62 & .87 & .00 & 1.66 & I & $\mathrm{P}$ & 47 \\
\hline 422033 & 720844 & 5.54 & 3.37 & .06 & 5.10 & I & $\mathrm{P}$ & 57 \\
\hline 422206 & 721316 & 4.20 & 1.57 & .16 & 3.63 & I & $\mathrm{P}$ & 9 \\
\hline 421456 & 721553 & 6.60 & 1.64 & 15.15 & 4.27 & $\mathrm{P}$ & $\mathrm{P}$ & 80 \\
\hline 422842 & 722005 & 3.39 & 2.35 & 2.06 & 6.53 & $\mathrm{P}$ & $\mathrm{P}$ & 53 \\
\hline 422849 & 721327 & 5.03 & 1.25 & 14.31 & 4.60 & $\mathrm{P}$ & $\mathrm{P}$ & 73 \\
\hline 422008 & 722212 & 2.89 & 2.07 & .69 & 5.96 & $\mathrm{P}$ & $\mathrm{P}$ & 43 \\
\hline 421730 & 720004 & 6.13 & 2.93 & 1.36 & 4.67 & I & $\mathrm{P}$ & 65 \\
\hline 421554 & 720019 & 8.69 & 1.93 & 12.77 & 5.46 & $\mathrm{P}$ & $\mathrm{P}$ & 89 \\
\hline 421927 & 720244 & 1.65 & 2.55 & .23 & 2.86 & I & $\mathrm{P}$ & 14 \\
\hline 421209 & 720304 & 4.06 & 3.23 & .10 & 2.97 & I & $\mathrm{P}$ & \\
\hline 421051 & 720609 & 2.60 & 2.86 & 4.05 & 4.09 & I & $\mathrm{P}$ & 30 \\
\hline 421401 & 720805 & 8.04 & 3.40 & .41 & 3.42 & I & $\mathrm{P}$ & 68 \\
\hline 421331 & 721012 & 3.55 & 2.16 & 18.87 & 5.64 & $\mathrm{P}$ & $\mathrm{P}$ & 60 \\
\hline 421256 & 721224 & 1.30 & 3.45 & .14 & 6.93 & I & $\mathrm{P}$ & 17 \\
\hline
\end{tabular}

78

81

85

70

47

11

3

89

30

68
60

17 
Table 4. Description, basin characteristics, and perennial- or intermittent-status determination for stream sites at discontinued and continuous streamflow-gaging stations and partial-record stations by region and major river basin in Massachusetts used in development of the logistic regression equation for estimating the probability of a stream flowing perennially in Massachusetts - Continued

\begin{tabular}{|c|c|c|c|c|c|c|c|c|c|c|}
\hline $\begin{array}{l}\text { USGS } \\
\text { station } \\
\text { No. }\end{array}$ & Station name & $\begin{array}{l}\text { Latitude } \\
\circ, 11\end{array}$ & $\underset{\substack{\text { Longitude } \\
\text { Lol }}}{ }$ & $\begin{array}{c}\text { Drainage } \\
\text { area } \\
\left(\mathrm{mi}^{2}\right)\end{array}$ & $\begin{array}{c}\text { Drainage } \\
\text { density } \\
\left(\mathrm{mi} / \mathrm{mi}^{2}\right)\end{array}$ & $\begin{array}{l}\text { Area of } \\
\text { stratified- } \\
\text { drift } \\
\text { deposits } \\
(\%)\end{array}$ & $\begin{array}{c}\text { Mean } \\
\text { basin } \\
\text { slope } \\
(\%)\end{array}$ & $\begin{array}{l}\text { Measured or } \\
\text { recorded } \\
\text { status of } \\
\text { stream site }\end{array}$ & $\begin{array}{c}\text { USGS } \\
\text { topographic } \\
\text { map designation } \\
\text { of status of } \\
\text { stream site }\end{array}$ & $\begin{array}{l}\text { Probability } \\
\text { of stream } \\
\text { flowing } \\
\text { perennially at } \\
\text { stream site } \\
(\%)\end{array}$ \\
\hline \multicolumn{11}{|c|}{ WESTERN REGION-Continued } \\
\hline \multicolumn{11}{|c|}{ Chicopee River Basin-Continued } \\
\hline 01176100 & Blodgett Mill Brook at West Brimfield & 421013 & 721541 & 7.71 & 3.33 & 1.07 & 4.36 & $\mathrm{P}$ & $\mathrm{P}$ & 72 \\
\hline 01176200 & Kings Brook at West Brimfield & 420941 & 721608 & 3.96 & 1.24 & 27.27 & 7.07 & $\mathrm{P}$ & $\mathrm{P}$ & 77 \\
\hline 01176300 & Foskett Mill Stream near Fentonville & 420743 & 721531 & 6.57 & 1.33 & 21.46 & 8.54 & $\mathrm{P}$ & $\mathrm{P}$ & 91 \\
\hline 01176450 & Roaring Brook near Belchertown & 421407 & 722418 & 2.77 & 2.17 & .62 & 3.76 & I & $\mathrm{P}$ & 31 \\
\hline \multicolumn{11}{|c|}{ Westfield River Basin } \\
\hline 01179900 & Trout Brook at West Worthington & 422521 & 725919 & 6.46 & 1.05 & 2.94 & 5.34 & $\mathrm{P}$ & $\mathrm{P}$ & 80 \\
\hline 01180000 & Sykes Brook at Knightville & 421727 & 725215 & 1.74 & 1.46 & .00 & 9.72 & $\mathrm{P}$ & $\mathrm{P}$ & 45 \\
\hline 01180650 & Shaker Mill Brook at Becket & 421956 & 730509 & 6.35 & 2.08 & .00 & 4.74 & $\mathrm{P}$ & $\mathrm{P}$ & 69 \\
\hline 01180800 & Walker Brook near Becket Center & 421549 & 730248 & 2.95 & 2.37 & 4.07 & 4.76 & $\mathrm{P}$ & $\mathrm{P}$ & 40 \\
\hline 01180900 & $\begin{array}{l}\text { Roaring Brook at Fisk Avenue near } \\
\text { Huntington }\end{array}$ & 421422 & 725412 & 3.64 & 1.75 & .43 & 5.76 & I & $\mathrm{P}$ & 53 \\
\hline \multicolumn{11}{|c|}{ Farmington River Basin } \\
\hline 01187400 & Valley Brook near West Hartland, Conn. & 420203 & 725549 & 7.37 & 1.66 & 9.50 & 11.04 & $\mathrm{P}$ & $\mathrm{P}$ & 94 \\
\hline \multicolumn{11}{|c|}{ Housatonic River Basin } \\
\hline 01197080 & $\begin{array}{l}\text { North Branch Mount Lebanon Brook at } \\
\text { Shaker Village }\end{array}$ & 422538 & 732102 & .46 & 2.81 & .00 & 10.52 & I & $\mathrm{P}$ & 14 \\
\hline 01197090 & Mount Lebanon Brook near Shaker Village & 422523 & 732040 & 1.26 & 2.49 & .00 & 10.61 & I & $\mathrm{P}$ & 33 \\
\hline 01197130 & Sykes Brook at Pittsfield & 422507 & 731335 & .81 & 1.90 & .00 & 10.82 & $\mathrm{P}$ & $\mathrm{P}$ & 27 \\
\hline 01197140 & Yokun Brook near Lenox & 422251 & 731526 & 5.95 & 1.26 & .50 & 8.59 & $\mathrm{P}$ & $\mathrm{P}$ & 85 \\
\hline 01197180 & Greenwater Brook at East Lee & 421759 & 731253 & 7.62 & 1.17 & 10.24 & 12.36 & $\mathrm{P}$ & $\mathrm{P}$ & 96 \\
\hline 01197200 & Hop Brook near Tyringham & 421249 & 730955 & 4.07 & 1.50 & 7.37 & 7.88 & $P$ & $\mathrm{P}$ & 74 \\
\hline 01197210 & $\begin{array}{l}\text { Unnamed Tributary, Monterey Road, near } \\
\text { Tyringham }\end{array}$ & 421321 & 731153 & .78 & 1.28 & .00 & 10.86 & $\mathrm{P}$ & $\mathrm{P}$ & 30 \\
\hline 01197240 & West Brook near South Lee & 421522 & 731711 & 4.16 & 1.57 & .00 & 6.46 & $\mathrm{P}$ & $\mathrm{P}$ & 61 \\
\hline 01197300 & Marsh Brook at Lenox & 422059 & 731756 & 2.18 & .86 & .46 & 9.29 & I & $\mathrm{P}$ & 56 \\
\hline 01197600 & Baldwin Brook near State Line & 421948 & 732458 & 2.34 & 1.54 & 8.37 & 11.08 & I & $\mathrm{P}$ & 69 \\
\hline
\end{tabular}


Table 4. Description, basin characteristics, and perennial- or intermittent-status determination for stream sites at discontinued and continuous streamflow-gaging stations and partial-record stations by region and major river basin in Massachusetts used in development of the logistic regression equation for estimating the probability of a stream flowing perennially in Massachusetts - Continued

\begin{tabular}{|c|c|c|c|c|c|c|c|c|c|c|}
\hline $\begin{array}{c}\text { USGS } \\
\text { station } \\
\text { No. }\end{array}$ & Station name & $\begin{array}{l}\text { Latitude } \\
\circ, 11\end{array}$ & $\underset{0,11}{\text { Longitude }}$ & $\begin{array}{c}\text { Drainage } \\
\text { area } \\
\left(\mathbf{m i}^{2}\right)\end{array}$ & $\begin{array}{c}\text { Drainage } \\
\text { density } \\
\left(\mathbf{m i} / \mathbf{m i}^{2}\right)\end{array}$ & $\begin{array}{l}\text { Area of } \\
\text { stratified- } \\
\text { drift } \\
\text { deposits } \\
(\%)\end{array}$ & $\begin{array}{c}\text { Mean } \\
\text { basin } \\
\text { slope } \\
(\%)\end{array}$ & $\begin{array}{l}\text { Measured or } \\
\text { recorded } \\
\text { status of } \\
\text { stream site }\end{array}$ & $\begin{array}{c}\text { USGS } \\
\text { topographic } \\
\text { map designation } \\
\text { of status of } \\
\text { stream site }\end{array}$ & $\begin{array}{l}\text { Probability } \\
\text { of stream } \\
\text { flowing } \\
\text { perennially at } \\
\text { stream site } \\
\text { (\%) }\end{array}$ \\
\hline \multicolumn{11}{|c|}{ WESTERN REGION-Continued } \\
\hline \multicolumn{11}{|c|}{ Housatonic River Basin--Continued } \\
\hline 01197700 & $\begin{array}{l}\text { Cone Brook at Sleepy Hollow Road near } \\
\text { Richmond }\end{array}$ & 422317 & 732135 & 3.49 & 1.49 & .00 & 6.20 & I & $\mathrm{P}$ & 53 \\
\hline 01197960 & Scribner Brook near Alford & 421642 & 732546 & 1.95 & 2.17 & 1.03 & 13.86 & $\mathrm{P}$ & $\mathrm{P}$ & 66 \\
\hline 01198020 & Sages Ravine Brook near Taconic, Conn. & 420258 & 732549 & 3.35 & .80 & 26.87 & 13.90 & $\mathrm{P}$ & $\mathrm{P}$ & 91 \\
\hline 01198040 & $\begin{array}{l}\text { Karner Brook near Mount Washington Road } \\
\text { near South Egremont }\end{array}$ & 420937 & 732809 & 1.91 & 1.75 & .00 & 15.45 & $\mathrm{P}$ & $\mathrm{P}$ & 72 \\
\hline 01198060 & Fenton Brook near South Egremont & 420917 & 732651 & 2.91 & 1.10 & 2.75 & 18.95 & I & $\mathrm{P}$ & 93 \\
\hline 01198062 & $\begin{array}{l}\text { Unnamed Tributary, Rt.23, near South } \\
\text { Egremont }\end{array}$ & 420955 & 732640 & 1.71 & 1.33 & .00 & 5.28 & $\mathrm{P}$ & $P$ & 26 \\
\hline 01198070 & Willard Brook near Sheffield & 420641 & 732338 & 3.70 & 1.74 & 28.11 & 13.77 & $\mathrm{P}$ & $\mathrm{P}$ & 91 \\
\hline 01198100 & Ironworks Brook near Sheffield & 420632 & 731859 & 8.29 & 1.12 & 1.21 & 7.89 & $\mathrm{P}$ & $\mathrm{P}$ & 91 \\
\hline 01198110 & Soda Creek at Fink Road near Sheffield & 420735 & 731949 & 1.59 & 1.37 & .28 & 13.04 & $\mathrm{P}$ & $\mathrm{P}$ & 60 \\
\hline 01198120 & Soda Creek at County Road near Sheffield & 420625 & 731938 & 2.87 & 1.25 & 11.29 & 10.15 & I & $\mathrm{P}$ & 74 \\
\hline 01198137 & Unnamed Tributary, Hupi Road, at Monterey & 421126 & 731215 & 1.05 & 1.72 & .00 & 5.46 & I & $P$ & 15 \\
\hline 01198160 & Umpachene River at Southfield & 420526 & 731440 & 8.46 & 2.23 & 3.19 & 6.22 & $\mathrm{P}$ & $\mathrm{P}$ & 87 \\
\hline 01198260 & $\begin{array}{l}\text { Whiting River, Campbell Falls Road, near } \\
\text { Canaan Valley, Conn. }\end{array}$ & 420246 & 731400 & 8.87 & 1.35 & 9.70 & 4.27 & $\mathrm{P}$ & $\mathrm{P}$ & 88 \\
\hline \multicolumn{11}{|c|}{ Hudson River Basin } \\
\hline 01331380 & South Brook at Cheshire & 423340 & 730906 & 7.03 & 1.82 & .28 & 10.47 & $\mathrm{P}$ & $\mathrm{P}$ & 90 \\
\hline 01331400 & Dry Brook near Adams & 423520 & 730648 & 7.68 & 1.25 & 2.73 & 8.19 & $\mathrm{P}$ & $\mathrm{P}$ & 91 \\
\hline 01331960 & Hudson Brook at Middle Road at Clarksburg & 424259 & 730548 & 7.36 & 1.31 & 8.19 & 8.87 & $\mathrm{P}$ & $\mathrm{P}$ & 92 \\
\hline 01332900 & $\begin{array}{l}\text { Hopper Brook, Hopper Road, near South } \\
\text { Williamstown }\end{array}$ & 424038 & 731239 & 6.70 & 1.23 & 3.28 & 24.58 & $\mathrm{P}$ & $\mathrm{P}$ & 99 \\
\hline 01333100 & Hemlock Brook near Williamstown & 424116 & 731350 & 5.25 & 1.93 & 8.38 & 19.38 & $\mathrm{P}$ & $\mathrm{P}$ & 97 \\
\hline
\end{tabular}


Table 5. Description, basin characteristics, and perennial- or intermittent-status determination for field-visited stream sites by town in the South Coastal Basin, southeastern Massachusetts used in development of the logistic regression equation for estimating the probability of a stream flowing perennially in Massachusetts

[Station No: Locations shown in figure 2. Latitude and longitude: Given in degrees, minutes, seconds. CT, Cohasset; DY, Duxbury; HR, Hanover; HN, Hanson; I, Intermittent; KN, Kingston; MD, Marshfield; NL, Norwell; P, Perennial; PE, Pembroke; RD, Rockland; SE, Scituate; USGS, U.S. Geological Survey; mi/mi ${ }^{2}$, miles per square mile; mi ${ }^{2}$, square mile; \%, percent]

\begin{tabular}{|c|c|c|c|c|c|c|c|c|c|c|c|}
\hline $\begin{array}{l}\text { Station } \\
\text { No. }\end{array}$ & Stream-site name and location & \begin{tabular}{l} 
Latitude \\
\hdashline,$\|$
\end{tabular} & $\underset{0,11}{\text { Longitude }}$ & $\begin{array}{c}\text { Drainage } \\
\text { area } \\
\left(\mathrm{mi}^{2}\right)\end{array}$ & $\begin{array}{c}\text { Drainage } \\
\text { density } \\
\left(\mathrm{mi}^{2} / \mathrm{mi}^{2}\right)\end{array}$ & $\begin{array}{l}\text { Area of } \\
\text { stratified- } \\
\text { drift } \\
\text { deposits } \\
(\%)\end{array}$ & $\begin{array}{c}\text { Mean } \\
\text { basin } \\
\text { slope } \\
(\%)\end{array}$ & $\begin{array}{c}\text { Date } \\
\text { status of } \\
\text { stream } \\
\text { site was } \\
\text { observed }\end{array}$ & $\begin{array}{l}\text { Observed } \\
\text { status } \\
\text { of stream } \\
\text { site }\end{array}$ & $\begin{array}{l}\text { USGS topo- } \\
\text { graphic } \\
\text { map desig- } \\
\text { nation of } \\
\text { status of } \\
\text { stream site }\end{array}$ & $\begin{array}{l}\text { Probability } \\
\text { of stream } \\
\text { flowing } \\
\text { perennially } \\
\text { at stream } \\
\text { site; } \\
\text { (\%) }\end{array}$ \\
\hline \multicolumn{12}{|c|}{ Cohasset } \\
\hline CT-04 & Unnamed Tributary to The Gulf, Main Street & 421336 & 704733 & 0.41 & 1.65 & 0.00 & 0.68 & $7-15-99$ & I & $\mathrm{P}$ & 53 \\
\hline CT-10 & $\begin{array}{l}\text { Unnamed Tributary to Lily Pond, } \\
\text { State Route 3A }\end{array}$ & 421346 & 704844 & .27 & 2.05 & .00 & .55 & $7-15-99$ & $\mathrm{P}$ & $\mathrm{P}$ & 45 \\
\hline \multicolumn{12}{|c|}{ Duxbury } \\
\hline DY-04 & Bassett Brook, State Route 53 & 420129 & 704411 & 0.09 & 1.25 & 99.52 & 1.61 & $8-05-99$ & $\mathrm{P}$ & I & 60 \\
\hline DY-05 & $\begin{array}{l}\text { Unnamed Tributary to Bassett Brook, } \\
\text { Winter Street }\end{array}$ & 420129 & 704432 & .14 & .59 & 40.58 & .96 & $8-05-99$ & I & I & 55 \\
\hline DY-11 & Unnamed Tributary to Kingston Bay, Bay Road & 420118 & 704110 & .09 & 3.39 & 100.00 & .97 & $8-05-99$ & $\mathrm{P}$ & I & 43 \\
\hline DY-12 & $\begin{array}{l}\text { Unnamed Tributary to Kingston Bay, } \\
\text { Old Railroad Grade }\end{array}$ & 420120 & 704150 & .08 & 1.13 & 100.00 & .96 & $8-05-99$ & I & I & 56 \\
\hline DY-13 & $\begin{array}{l}\text { Unnamed Tributary to South River, } \\
\text { Chandler Street }\end{array}$ & 420224 & 704422 & .22 & .47 & 100.00 & .82 & $8-05-99$ & I & $\mathrm{P}$ & 72 \\
\hline DY-14 & Unnamed Tributary to South River, Bianca Road & 420226 & 704415 & .30 & .76 & 100.00 & .80 & $8-05-99$ & $\mathrm{I}$ & $\mathrm{P}$ & 75 \\
\hline DY-15 & Unnamed Tributary to South River, Bolas Road & 420227 & 704408 & .31 & 1.07 & 100.00 & .80 & $8-05-99$ & $\mathrm{P}$ & $\mathrm{P}$ & 73 \\
\hline DY-21 & Halls Brook, Autumn Avenue & 420139 & 704459 & .18 & 1.13 & 81.48 & .43 & $8-05-99$ & $\mathrm{P}$ & $\mathrm{P}$ & 62 \\
\hline DY-25 & Keene Brook, Union Street & 420422 & 704519 & .83 & 1.69 & 35.32 & .88 & 8-06-99 & I & $\mathrm{P}$ & 78 \\
\hline DY-26 & Keene Brook, Congress Street & 420345 & 704545 & .24 & .37 & 84.48 & .39 & $8-06-99$ & $\mathrm{P}$ & I & 70 \\
\hline DY-27 & Unnamed Tributary to Pine Brook, Pine Street & 420130 & 704556 & .12 & 5.22 & 100.00 & .71 & $8-05-99$ & I & $\mathrm{P}$ & 34 \\
\hline DY-29 & Halls Brook, Hitty Tom Road & 420119 & 704511 & .77 & 2.01 & 94.42 & .54 & $8-05-99$ & $\mathrm{P}$ & $\mathrm{P}$ & 81 \\
\hline DY-30 & Halls Brook, Clearwater Drive & 420134 & 704509 & .62 & 1.41 & 94.07 & .49 & $8-05-99$ & $\mathrm{P}$ & $\mathrm{P}$ & 81 \\
\hline DY-31 & $\begin{array}{l}\text { Unnamed Tributary to Halls Brook, } \\
\text { Clearwater Drive }\end{array}$ & 420145 & 704510 & .22 & 1.27 & 100.00 & .47 & 8-05-99 & $\mathrm{P}$ & $\mathrm{P}$ & 66 \\
\hline DY-37 & $\begin{array}{l}\text { Unnamed Tributary to Pudding Brook, } \\
\text { Keene Street }\end{array}$ & 420503 & 704516 & .09 & .98 & 55.35 & 2.33 & 8-06-99 & $\mathrm{P}$ & $\mathrm{P}$ & 57 \\
\hline
\end{tabular}


Table 5. Description, basin characteristics, and perennial- or intermittent-status determination for field-visited stream sites by town in the South Coastal Basin, southeastern Massachusetts used in development of the logistic regression equation for estimating the probability of a stream flowing perennially in Massachusetts - Continued

\begin{tabular}{|c|c|c|c|c|c|c|c|c|c|c|c|}
\hline $\begin{array}{l}\text { Station } \\
\text { No. }\end{array}$ & Stream-site name and location & $\begin{array}{l}\text { Latitude } \\
\circ, 11\end{array}$ & $\underset{\substack{\text { Longitude } \\
0,11}}{ }$ & $\begin{array}{c}\text { Drainage } \\
\text { area } \\
\left(\mathbf{m i}^{2}\right)\end{array}$ & $\begin{array}{c}\text { Drainage } \\
\text { density } \\
\left(\mathrm{mi} / \mathrm{mi}^{2}\right)\end{array}$ & $\begin{array}{c}\text { Area of } \\
\text { stratified- } \\
\text { drift } \\
\text { deposits } \\
(\%)\end{array}$ & $\begin{array}{c}\text { Mean } \\
\text { basin } \\
\text { slope } \\
(\%)\end{array}$ & $\begin{array}{c}\text { Date } \\
\text { status of } \\
\text { stream } \\
\text { site was } \\
\text { observed }\end{array}$ & $\begin{array}{l}\text { Observed } \\
\text { status } \\
\text { of stream } \\
\text { site }\end{array}$ & $\begin{array}{l}\text { USGS topo- } \\
\text { graphic } \\
\text { map desig- } \\
\text { nation of } \\
\text { status of } \\
\text { stream site }\end{array}$ & $\begin{array}{l}\text { Probability } \\
\text { of stream } \\
\text { flowing } \\
\text { perennially } \\
\text { at stream } \\
\text { site; } \\
(\%)\end{array}$ \\
\hline \multicolumn{12}{|c|}{ Duxbury-Continued } \\
\hline DY-41 & Unnamed Tributary to Kingston Bay, Bay Road & 420100 & 704146 & 0.22 & 2.21 & 100.00 & 1.28 & $8-05-88$ & $\mathrm{P}$ & I & 64 \\
\hline DY-53 & $\begin{array}{l}\text { Unnamed Tributary to Bluefish River, } \\
\text { Partridge Road }\end{array}$ & 420139 & 704040 & .27 & .43 & 100.00 & 1.15 & $9-03-99$ & I & $P$ & 76 \\
\hline DY-54 & $\begin{array}{l}\text { Unnamed Tributary to Bluefish River, } \\
\text { Surplus Street }\end{array}$ & 420143 & 704037 & .54 & .64 & 100.00 & .96 & $9-03-99$ & $P$ & $P$ & 83 \\
\hline \multicolumn{12}{|c|}{ Hanover } \\
\hline HR-03 & Iron Mine Brook, Rockland Street & 420652 & 704920 & 0.06 & 1.53 & 100.00 & 1.91 & $8-12-99$ & $\mathrm{P}$ & $\mathrm{P}$ & 55 \\
\hline HR-07 & $\begin{array}{l}\text { Unnamed Tributary to Indian Head River, } \\
\text { Water Street }\end{array}$ & 420608 & 704933 & .27 & 3.15 & 100.00 & .90 & 8-13-99 & $\mathrm{P}$ & $\mathrm{P}$ & 60 \\
\hline HR-08 & $\begin{array}{l}\text { Unnamed Tributary to Indian Head River, } \\
\text { Water Street }\end{array}$ & 420549 & 705028 & .11 & 2.42 & 100.00 & .57 & 8-13-99 & I & I & 50 \\
\hline HR-09 & $\begin{array}{l}\text { Unnamed Tributary to Indian Head River, } \\
\text { Broadway Street }\end{array}$ & 420552 & 705053 & .56 & 3.03 & 100.00 & .69 & 8-13-99 & $\mathrm{P}$ & $\mathrm{P}$ & 73 \\
\hline HR-10 & $\begin{array}{l}\text { Unnamed Tributary to Indian Head River, } \\
\text { Broadway Street }\end{array}$ & 420618 & 705020 & .07 & 4.58 & 100.00 & .49 & 8-13-99 & I & I & 31 \\
\hline HR-11 & $\begin{array}{l}\text { Unnamed Tributary to Indian Head River, } \\
\text { Karen Road }\end{array}$ & 420614 & 704947 & .21 & 2.98 & 100.00 & 1.14 & 8-13-99 & $P$ & $\mathrm{P}$ & 58 \\
\hline HR-12 & $\begin{array}{l}\text { Unnamed Tributary to Indian Head River, } \\
\text { Broadway Street }\end{array}$ & 420627 & 704947 & .13 & 2.95 & 100.00 & .71 & 8-13-99 & $\mathrm{P}$ & $\mathrm{P}$ & 49 \\
\hline HR-13 & $\begin{array}{l}\text { Unnamed Tributary to Indian Head River, } \\
\text { Laurie Lane }\end{array}$ & 420633 & 704959 & .11 & 1.56 & 100.00 & .37 & 8-13-99 & $\mathrm{P}$ & $\mathrm{P}$ & 54 \\
\hline HR-15 & $\begin{array}{l}\text { Unnamed Tributary to Indian Head River, } \\
\text { Pine Tree Drive }\end{array}$ & 420632 & 705039 & .21 & 3.98 & 100.00 & .13 & 8-13-99 & $\mathrm{P}$ & $\mathrm{P}$ & 47 \\
\hline HR-16 & $\begin{array}{l}\text { Unnamed Tributary to Indian Head River, } \\
\text { Reed Drive }\end{array}$ & 420638 & 705039 & .17 & 4.22 & 100.00 & .02 & 8-13-99 & $\mathrm{P}$ & $\mathrm{P}$ & 42 \\
\hline
\end{tabular}


Table 5. Description, basin characteristics, and perennial- or intermittent-status determination for field-visited stream sites by town in the South Coastal Basin, southeastern Massachusetts used in development of the logistic regression equation for estimating the probability of a stream flowing perennially in Massachusetts - Continued

\begin{tabular}{|c|c|c|c|c|c|c|c|c|c|c|c|}
\hline $\begin{array}{l}\text { Station } \\
\text { No. }\end{array}$ & Stream-site name and location & $\begin{array}{l}\text { Latitude } \\
0,11\end{array}$ & Longitude & $\begin{array}{c}\text { Drainage } \\
\text { area } \\
\left(\mathrm{mi}^{2}\right)\end{array}$ & $\begin{array}{c}\text { Drainage } \\
\text { density } \\
\left(\mathrm{mi} / \mathrm{mi}^{2}\right)\end{array}$ & $\begin{array}{l}\text { Area of } \\
\text { stratified- } \\
\text { drift } \\
\text { deposits } \\
(\%)\end{array}$ & $\begin{array}{l}\text { Mean } \\
\text { basin } \\
\text { slope } \\
(\%)\end{array}$ & $\begin{array}{l}\text { Date } \\
\text { status of } \\
\text { stream } \\
\text { site was } \\
\text { observed }\end{array}$ & $\begin{array}{l}\text { Observed } \\
\text { status } \\
\text { of stream } \\
\text { site }\end{array}$ & $\begin{array}{l}\text { USGS topo- } \\
\text { graphic } \\
\text { map desig- } \\
\text { nation of } \\
\text { status of } \\
\text { stream site }\end{array}$ & $\begin{array}{l}\text { Probability } \\
\text { of stream } \\
\text { flowing } \\
\text { perennially } \\
\text { at stream } \\
\text { site; } \\
(\%)\end{array}$ \\
\hline \multicolumn{12}{|c|}{ Hanover-Continued } \\
\hline HR-22 & Mollys Brook, Grove Street & 420646 & 705110 & 0.07 & 3.26 & 100.00 & 0.10 & $8-12-99$ & I & $\mathrm{P}$ & 36 \\
\hline HR-25 & Torrey Brook, Winter Street & 420600 & 705209 & .64 & 1.30 & 100.00 & 1.02 & 8-13-99 & $\mathrm{P}$ & $P$ & 83 \\
\hline HR-28 & Mollys Brook, Main Street & 420706 & 705051 & .37 & 2.02 & 99.88 & .26 & $8-12-99$ & I & $\mathrm{P}$ & 69 \\
\hline HR-30 & Drinkwater Brook, Hanover Street & 420703 & 705237 & 7.00 & 3.05 & 62.09 & .71 & $8-12-99$ & $\mathrm{P}$ & $\mathrm{P}$ & 99 \\
\hline HR-31 & Cushing Brook, Hanover Street & 420705 & 705247 & 4.15 & 2.49 & 77.14 & .55 & $8-12-99$ & $\mathrm{P}$ & $\mathrm{P}$ & 97 \\
\hline HR-32 & $\begin{array}{l}\text { Unnamed Tributary to French Stream, } \\
\text { Summer Street }\end{array}$ & 420647 & 705315 & .23 & 4.34 & 99.17 & .54 & $8-13-99$ & $\mathrm{P}$ & $P$ & 48 \\
\hline HR-33 & Cushing Brook, Pleasant Street & 420711 & 705259 & 4.09 & 2.47 & 76.81 & .54 & $8-12-99$ & $P$ & $P$ & 97 \\
\hline HR-34 & $\begin{array}{l}\text { Unnamed Tributary to French Stream, } \\
\text { Hanover Street }\end{array}$ & 420711 & 705323 & .04 & 1.59 & 100.00 & .49 & $8-12-99$ & I & $P$ & 43 \\
\hline HR-39 & $\begin{array}{l}\text { Unnamed Tributary to Drinkwater River, } \\
\text { Union Street }\end{array}$ & 420754 & 705114 & .71 & .75 & 52.47 & 1.28 & $8-12-99$ & $\mathrm{P}$ & $\mathrm{P}$ & 83 \\
\hline HR-40 & $\begin{array}{l}\text { Unnamed Tributary to Drinkwater River, } \\
\text { Main Street }\end{array}$ & 420742 & 705128 & 1.03 & .87 & 59.85 & 1.28 & $8-12-99$ & $P$ & $\mathrm{P}$ & 88 \\
\hline HR-41 & $\begin{array}{l}\text { Unnamed Tributary to Drinkwater River, } \\
\text { Cedar Street }\end{array}$ & 420744 & 705138 & 1.09 & 1.00 & 62.37 & 1.22 & 8-10-99 & $\mathrm{P}$ & $\mathrm{P}$ & 88 \\
\hline HR-44 & $\begin{array}{l}\text { Unnamed Tributary to Drinkwater River, } \\
\text { Main Street }\end{array}$ & 420817 & 705152 & .31 & 1.88 & 30.49 & 1.17 & 8-10-99 & $\mathrm{P}$ & I & 58 \\
\hline HR-45 & $\begin{array}{l}\text { Unnamed Tributary to Drinkwater River, } \\
\text { Main Street }\end{array}$ & 420824 & 705153 & .24 & 1.82 & 27.94 & 1.24 & 8-10-99 & $\mathrm{P}$ & I & 54 \\
\hline HR-48 & $\begin{array}{l}\text { Unnamed Tributary to Shinglemill Brook, } \\
\text { Main Street }\end{array}$ & 420902 & 705210 & .17 & 3.28 & 73.87 & .46 & 8-10-99 & $\mathrm{P}$ & I & 45 \\
\hline HR-49 & $\begin{array}{l}\text { Unnamed Tributary to Hackett Pond, } \\
\text { Walnut Street }\end{array}$ & 420902 & 705150 & .46 & 1.21 & 27.12 & .46 & 8-10-99 & I & $P$ & 66 \\
\hline
\end{tabular}


Table 5. Description, basin characteristics, and perennial- or intermittent-status determination for field-visited stream sites by town in the South Coastal Basin, southeastern Massachusetts used in development of the logistic regression equation for estimating the probability of a stream flowing perennially in Massachusetts - Continued

\begin{tabular}{|c|c|c|c|c|c|c|c|c|c|c|c|}
\hline $\begin{array}{l}\text { Station } \\
\text { No. }\end{array}$ & Stream-site name and location & $\begin{array}{l}\text { Latitude } \\
\circ, 11\end{array}$ & Longitude & $\begin{array}{c}\text { Drainage } \\
\text { area } \\
\left(\mathbf{m i}^{2}\right)\end{array}$ & $\begin{array}{c}\text { Drainage } \\
\text { density } \\
\left(\mathrm{mi} / \mathrm{mi}^{2}\right)\end{array}$ & $\begin{array}{l}\text { Area of } \\
\text { stratified- } \\
\text { drift } \\
\text { deposits } \\
(\%)\end{array}$ & $\begin{array}{c}\text { Mean } \\
\text { basin } \\
\text { slope } \\
(\%)\end{array}$ & $\begin{array}{l}\text { Date } \\
\text { status of } \\
\text { stream } \\
\text { site was } \\
\text { observed }\end{array}$ & $\begin{array}{l}\text { Observed } \\
\text { status } \\
\text { of stream } \\
\text { site }\end{array}$ & $\begin{array}{l}\text { USGS topo- } \\
\text { graphic } \\
\text { map desig- } \\
\text { nation of } \\
\text { status of } \\
\text { stream site }\end{array}$ & $\begin{array}{l}\text { Probability } \\
\text { of stream } \\
\text { flowing } \\
\text { perennially } \\
\text { at stream } \\
\text { site; } \\
(\%)\end{array}$ \\
\hline \multicolumn{12}{|c|}{ Hanover-Continued } \\
\hline HR-50 & $\begin{array}{l}\text { Unnamed Tributary to Drinkwater River, } \\
\text { Dillingham Street }\end{array}$ & 420840 & 705145 & 0.10 & 0.98 & 0.00 & 1.82 & $8-10-99$ & $\mathrm{P}$ & I & 33 \\
\hline HR-53 & $\begin{array}{l}\text { Unnamed Tributary to Drinkwater River, } \\
\text { West Street }\end{array}$ & 420740 & 705229 & 3.99 & 3.97 & 52.70 & .58 & $8-10-99$ & $\mathrm{P}$ & $\mathrm{P}$ & 95 \\
\hline HR-54 & $\begin{array}{l}\text { Unnamed Tributary to Drinkwater River, } \\
\text { Cedar Street }\end{array}$ & 420754 & 705254 & .89 & 9.34 & 57.00 & .23 & $8-10-99$ & I & $\mathrm{P}$ & 36 \\
\hline HR-55 & Longwater Brook, Cedarwood Road & 420855 & 705232 & 67 & 2.40 & 72.52 & .46 & $8-10-99$ & $\mathrm{P}$ & $\mathrm{P}$ & 75 \\
\hline HR-56 & Shinglemill Brook, Webster Street & 420840 & 705254 & .45 & 1.59 & 59.76 & 60 & $8-10-99$ & I & $\mathrm{P}$ & 70 \\
\hline HR-59 & $\begin{array}{l}\text { Unnamed Tributary to Shinglemill Brook, } \\
\text { Cedarwood Road }\end{array}$ & 420855 & 705216 & .36 & 2.03 & 79.24 & .63 & $8-10-99$ & $\mathrm{P}$ & $\mathrm{P}$ & 67 \\
\hline HR-60 & $\begin{array}{l}\text { Unnamed Tributary to Shinglemill Brook, } \\
\text { Brookwood Road }\end{array}$ & 420850 & 705216 & .39 & 2.14 & 73.79 & .73 & $8-10-99$ & $\mathrm{P}$ & $\mathrm{P}$ & 67 \\
\hline HR-61 & Shinglemill Brook, Webster Street & 420846 & 705215 & 1.14 & 2.52 & 67.70 & .59 & $8-10-99$ & $\mathrm{P}$ & $\mathrm{P}$ & 83 \\
\hline HR-62 & Shinglemill Brook, Hacketts Pond Drive & 420831 & 705236 & .54 & 2.09 & 49.43 & .71 & $8-10-99$ & I & $\mathrm{P}$ & 70 \\
\hline HR-63 & Shinglemill Brook, Country Road & 420830 & 705229 & .60 & 2.07 & 44.43 & .69 & 8-10-99 & I & $\mathrm{P}$ & 71 \\
\hline HR-65 & $\begin{array}{l}\text { Unnamed Tributary to Mann Brook, } \\
\text { Webster Street }\end{array}$ & 420817 & 705345 & .15 & 3.14 & 100.00 & .61 & 8-10-99 & I & $\mathrm{P}$ & 50 \\
\hline HR-68 & $\begin{array}{l}\text { Unnamed Tributary to Shinglemill Brook, } \\
\text { Cedarwood Road }\end{array}$ & 420854 & 705214 & .36 & 2.08 & 78.99 & .70 & 8-10-99 & $P$ & $\mathrm{P}$ & 67 \\
\hline \multicolumn{12}{|c|}{ Hanson } \\
\hline $\mathrm{HN}-03$ & $\begin{array}{l}\text { Unnamed Tributary to Indian Head Brook, } \\
\text { Puritan Street }\end{array}$ & 420513 & 705121 & 0.11 & 3.89 & 66.28 & 1.96 & 7-19-99 & $\mathrm{P}$ & I & 42 \\
\hline $\mathrm{HN}-04$ & $\begin{array}{l}\text { Unnamed Tributary to Indian Head Brook, } \\
\text { Old Pine Drive }\end{array}$ & 420510 & 705112 & .06 & 4.71 & 45.72 & 2.69 & 7-19-99 & $\mathrm{P}$ & I & 30 \\
\hline $\mathrm{HN}-05$ & $\begin{array}{l}\text { Unnamed Tributary to Indian Head Brook, } \\
\text { Winter Street }\end{array}$ & 420501 & 705154 & .02 & 8.33 & 100.00 & .74 & $7-19-99$ & I & I & 11 \\
\hline $\mathrm{HN}-07$ & $\begin{array}{l}\text { Unnamed Tributary to Oldham Pond, State } \\
\text { Street }\end{array}$ & 420439 & 705045 & .21 & .36 & 100.00 & .91 & 7-19-99 & I & $\mathrm{P}$ & 72 \\
\hline $\mathrm{HN}-08$ & $\begin{array}{l}\text { Unnamed Tributary to Oldham Pond, } \\
\text { Brook Street }\end{array}$ & 420432 & 705044 & .23 & .85 & 100.00 & .83 & 7-19-99 & I & $\mathrm{P}$ & 71 \\
\hline
\end{tabular}


Table 5. Description, basin characteristics, and perennial- or intermittent-status determination for field-visited stream sites by town in the South Coastal Basin, southeastern Massachusetts used in development of the logistic regression equation for estimating the probability of a stream flowing perennially in Massachusetts - Continued

\begin{tabular}{|c|c|c|c|c|c|c|c|c|c|c|c|}
\hline $\begin{array}{l}\text { Station } \\
\text { No. }\end{array}$ & Stream-site name and location & $\begin{array}{l}\text { Latitude } \\
\circ, 11\end{array}$ & $\underset{\substack{\text { Longitude } \\
0,11}}{ }$ & $\begin{array}{c}\text { Drainage } \\
\text { area } \\
\left(\mathbf{m i}^{2}\right)\end{array}$ & $\begin{array}{c}\text { Drainage } \\
\text { density } \\
\left(\mathrm{mi} / \mathrm{mi}^{2}\right)\end{array}$ & $\begin{array}{l}\text { Area of } \\
\text { stratified- } \\
\text { drift } \\
\text { deposits } \\
(\%)\end{array}$ & $\begin{array}{c}\text { Mean } \\
\text { basin } \\
\text { slope } \\
(\%)\end{array}$ & $\begin{array}{l}\text { Date } \\
\text { status of } \\
\text { stream } \\
\text { site was } \\
\text { observed }\end{array}$ & $\begin{array}{l}\text { Observed } \\
\text { status } \\
\text { of stream } \\
\text { site }\end{array}$ & $\begin{array}{l}\text { USGS topo- } \\
\text { graphic } \\
\text { map desig- } \\
\text { nation of } \\
\text { status of } \\
\text { stream site }\end{array}$ & $\begin{array}{l}\text { Probability } \\
\text { of stream } \\
\text { flowing } \\
\text { perennially } \\
\text { at stream } \\
\text { site; } \\
(\%)\end{array}$ \\
\hline \multicolumn{12}{|c|}{ Hanson-Continued } \\
\hline $\mathrm{HN}-14$ & $\begin{array}{l}\text { Unnamed Tributary to Factory Pond, } \\
\text { Whitman Street }\end{array}$ & 420455 & 705255 & 0.09 & 3.26 & 23.56 & 0.09 & $7-19-99$ & I & I & 26 \\
\hline $\mathrm{HN}-15$ & Unnamed Tributary to Factory Pond, King Street & 420514 & 705242 & 68 & 2.36 & 57.12 & .71 & 7-19-99 & $\mathrm{P}$ & $\mathrm{P}$ & 74 \\
\hline $\mathrm{HN}-16$ & $\begin{array}{l}\text { Unnamed Tributary to Factory Pond, } \\
\text { Whitman Street }\end{array}$ & 420458 & 705235 & .06 & 1.26 & 100.00 & 1.72 & $7-19-99$ & I & I & 56 \\
\hline \multicolumn{12}{|c|}{ Kingston } \\
\hline $\mathrm{KN}-07$ & Unnamed Tributary to Jones River, Brook Street & 415917 & 704402 & 0.22 & 2.11 & 86.56 & 3.36 & 9-03-99 & $\mathrm{P}$ & I & 72 \\
\hline $\mathrm{KN}-11$ & $\begin{array}{l}\text { Unnamed Tributary to Soules Pond, } \\
\text { Sylvia Place Road }\end{array}$ & 415852 & 704450 & 1.45 & 5.50 & 100.00 & 1.21 & $8-31-99$ & I & $\mathrm{P}$ & 81 \\
\hline $\mathrm{KN}-15$ & Bassett Brook, Winthrop Street & 420032 & 704440 & .86 & 4.78 & 80.05 & 1.21 & $8-31-99$ & $P$ & $\mathrm{P}$ & 71 \\
\hline $\mathrm{KN}-17$ & Jones River, Lake Street & 420047 & 704716 & 4.18 & 3.60 & 100.00 & .93 & $8-31-99$ & $\mathrm{P}$ & $\mathrm{P}$ & 97 \\
\hline $\mathrm{KN}-18$ & Jones River, Grove Street & 420012 & 704709 & 4.47 & 3.70 & 100.00 & .87 & $8-31-99$ & $\mathrm{P}$ & $\mathrm{P}$ & 97 \\
\hline $\mathrm{KN}-21$ & $\begin{array}{l}\text { Unnamed Tributary to Jones River, } \\
\text { Pembroke Street }\end{array}$ & 420038 & 704549 & .09 & .50 & 86.41 & .24 & $8-31-99$ & I & $\mathrm{P}$ & 56 \\
\hline $\mathrm{KN}-22$ & Unnamed Tributary to Jones River, Reed Street & 420036 & 704548 & .10 & .87 & 86.85 & .15 & $8-31-99$ & I & $\mathrm{P}$ & 54 \\
\hline $\mathrm{KN}-31$ & Smelt Brook, Main Street & 415846 & 704232 & 1.85 & 1.97 & 96.95 & 2.76 & $9-03-99$ & $\mathrm{P}$ & $\mathrm{P}$ & 95 \\
\hline \multicolumn{12}{|c|}{ Marshfield } \\
\hline MD-01 & Hannah Eames Brook, State Route 3A & 420907 & 704435 & 0.68 & 1.83 & 0.00 & 2.83 & $8-23-99$ & I & $\mathrm{P}$ & 65 \\
\hline MD-20 & Furnace Brook, School Street & 420706 & 704432 & .88 & 1.29 & 2.55 & 3.93 & $8-23-99$ & $\mathrm{P}$ & $\mathrm{P}$ & 81 \\
\hline MD-26 & $\begin{array}{l}\text { Unnamed Tributary to South River, } \\
\text { South River Road }\end{array}$ & 420623 & 704157 & .02 & 7.93 & 100.00 & .61 & $8-30-99$ & I & $\mathrm{P}$ & 12 \\
\hline MD-34 & Unnamed Tributary to Cove Brook, Oak Street & 420826 & 704525 & .22 & .97 & .00 & 4.34 & $8-23-99$ & $\mathrm{P}$ & I & 56 \\
\hline MD-35 & Unnamed Tributary to Cove Brook, Union Street & 420807 & 704607 & .03 & .41 & 4.08 & 3.77 & $8-23-99$ & I & I & 39 \\
\hline MD-36 & $\begin{array}{l}\text { Unnamed Tributary to Oakham Pond, } \\
\text { Stonewood Drive }\end{array}$ & 420741 & 704523 & .23 & 1.46 & .00 & 4.35 & $8-23-99$ & $\mathrm{P}$ & I & 54 \\
\hline MD-47 & Cut River, Canal Street & 420418 & 703908 & .24 & 7.30 & 97.70 & .59 & $9-03-99$ & I & $\mathrm{P}$ & 31 \\
\hline
\end{tabular}


Table 5. Description, basin characteristics, and perennial- or intermittent-status determination for field-visited stream sites by town in the South Coastal Basin, southeastern Massachusetts used in development of the logistic regression equation for estimating the probability of a stream flowing perennially in Massachusetts -Continued

\begin{tabular}{|c|c|c|c|c|c|c|c|c|c|c|c|}
\hline $\begin{array}{l}\text { Station } \\
\text { No. }\end{array}$ & Stream-site name and location & \begin{tabular}{l} 
Latitude \\
\hdashline, $1 "$
\end{tabular} & $\underset{0,11}{\text { Longitude }}$ & $\begin{array}{c}\text { Drainage } \\
\text { area } \\
\left(\mathbf{m i}^{2}\right)\end{array}$ & $\begin{array}{c}\text { Drainage } \\
\text { density } \\
\left(\mathrm{mi} / \mathrm{mi}^{2}\right)\end{array}$ & $\begin{array}{c}\text { Area of } \\
\text { stratified- } \\
\text { drift } \\
\text { deposits } \\
(\%)\end{array}$ & $\begin{array}{c}\text { Mean } \\
\text { basin } \\
\text { slope } \\
(\%)\end{array}$ & $\begin{array}{c}\text { Date } \\
\text { status of } \\
\text { stream } \\
\text { site was } \\
\text { observed }\end{array}$ & $\begin{array}{l}\text { Observed } \\
\text { status } \\
\text { of stream } \\
\text { site }\end{array}$ & $\begin{array}{l}\text { USGS topo- } \\
\text { graphic } \\
\text { map desig- } \\
\text { nation of } \\
\text { status of } \\
\text { stream site }\end{array}$ & $\begin{array}{l}\text { Probability } \\
\text { of stream } \\
\text { flowing } \\
\text { perennially } \\
\text { at stream } \\
\text { site; } \\
(\%)\end{array}$ \\
\hline \multicolumn{12}{|c|}{ Norwell } \\
\hline NL-03 & Copeland Tannery Brook, Meadow Brook Road & 420701 & 704823 & 0.49 & 1.78 & 18.37 & 1.41 & $8-23-99$ & $\mathrm{P}$ & $\mathrm{P}$ & 65 \\
\hline NL-07 & $\begin{array}{l}\text { Unnamed Tributary to Burnt Plain Swamp, } \\
\text { Prospect Street }\end{array}$ & 420951 & 705021 & .13 & 4.40 & 81.09 & .25 & $8-20-99$ & I & $\mathrm{P}$ & 35 \\
\hline NL-12 & Wildcat Brook, Pleasant Street & 420858 & 704858 & .22 & 3.98 & 75.31 & 1.57 & $8-13-99$ & I & $\mathrm{P}$ & 51 \\
\hline NL-13 & $\begin{array}{l}\text { Unnamed Tributary to Wildcat Brook, } \\
\text { Forest Street }\end{array}$ & 420917 & 704826 & .54 & 2.37 & 6.36 & 2.30 & $8-13-99$ & I & I & 62 \\
\hline NL-14 & $\begin{array}{l}\text { Unnamed Tributary to Third Herring Brook, } \\
\text { Pine Street }\end{array}$ & 420744 & 704811 & .24 & 1.08 & 1.57 & 3.57 & $8-23-99$ & $\mathrm{P}$ & I & 57 \\
\hline NL-16 & $\begin{array}{l}\text { Unnamed Tributary to Wildcat Brook, } \\
\text { Circuit Street }\end{array}$ & 420905 & 704843 & .89 & 2.41 & 14.99 & 1.88 & $8-13-99$ & $\mathrm{P}$ & $\mathrm{P}$ & 74 \\
\hline NL-18 & $\begin{array}{l}\text { Unnamed Tributary to Second Herring Brook, } \\
\text { Mill Lane }\end{array}$ & 420953 & 704735 & 2.16 & 2.69 & 12.91 & 1.52 & $8-20-99$ & $\mathrm{P}$ & $\mathrm{P}$ & 88 \\
\hline NL-19 & $\begin{array}{l}\text { Unnamed Tributary to Second Herring Brook, } \\
\text { Central Street }\end{array}$ & 420957 & 704743 & 1.92 & 1.56 & 10.41 & 1.57 & $8-20-99$ & I & $\mathrm{P}$ & 89 \\
\hline NL-20 & $\begin{array}{l}\text { Unnamed Tributary to Second Herring Brook, } \\
\text { Central Street }\end{array}$ & 421024 & 704813 & .26 & .50 & 6.04 & 3.40 & $8-20-99$ & $\mathrm{P}$ & I & 65 \\
\hline NL-21 & $\begin{array}{l}\text { Unnamed Tributary to Second Herring Brook, } \\
\text { Trout Brook Lane }\end{array}$ & 421021 & 704814 & .27 & .71 & 5.89 & 3.26 & $8-20-99$ & $\mathrm{P}$ & I & 63 \\
\hline NL-24 & Stony Brook, Cross Street & 421018 & 704615 & .09 & 3.00 & 63.16 & .32 & $8-20-99$ & $\mathrm{P}$ & $\mathrm{P}$ & 36 \\
\hline NL-25 & $\begin{array}{l}\text { Unnamed Tributary to Stony Brook, } \\
\text { Parker Street }\end{array}$ & 420954 & 704627 & .33 & 2.31 & 19.37 & 1.45 & $8-20-99$ & I & $\mathrm{P}$ & 55 \\
\hline NL-29 & Stony Brook, Main Street & 420953 & 704601 & .79 & 2.56 & 45.61 & 1.47 & $8-20-99$ & $\mathrm{P}$ & $\mathrm{P}$ & 76 \\
\hline NL-33 & Wildcat Brook, Main Street & 420926 & 704900 & .10 & 2.48 & 86.13 & 2.26 & 8-13-99 & $\mathrm{P}$ & I & 54 \\
\hline NL-41 & Wildcat Brook, Wildcat Lane & 420843 & 704912 & 1.46 & 2.60 & 26.84 & 1.55 & $8-13-99$ & $\mathrm{P}$ & $\mathrm{P}$ & 84 \\
\hline NL-42 & $\begin{array}{l}\text { Unnamed Tributary to Wildcat Creek, } \\
\text { Norwell Avenue }\end{array}$ & 421024 & 704908 & .02 & 6.66 & 100.00 & 1.28 & $8-20-99$ & I & $\mathrm{P}$ & 15 \\
\hline NL-46 & $\begin{array}{l}\text { Unnamed Tributary to Third Herring Brook, } \\
\text { Leonard Lane }\end{array}$ & 420734 & 704817 & .27 & 1.76 & 5.35 & 3.36 & $8-23-99$ & $\mathrm{P}$ & I & 57 \\
\hline NL-47 & $\begin{array}{l}\text { Unnamed Tributary to Third Herring Brook, } \\
\text { Tiffany Street }\end{array}$ & 420732 & 704830 & .36 & 1.84 & 6.17 & 3.07 & $8-23-99$ & $\mathrm{P}$ & I & 61 \\
\hline
\end{tabular}


Table 5. Description, basin characteristics, and perennial- or intermittent-status determination for field-visited stream sites by town in the South Coastal Basin, southeastern Massachusetts used in development of the logistic regression equation for estimating the probability of a stream flowing perennially in Massachusetts - Continued

\begin{tabular}{|c|c|c|c|c|c|c|c|c|c|c|c|}
\hline $\begin{array}{l}\text { Station } \\
\text { No. }\end{array}$ & Stream-site name and location & $\begin{array}{l}\text { Latitude } \\
\circ, 11\end{array}$ & $\underset{0,11}{\text { Longitude }}$ & $\begin{array}{c}\text { Drainage } \\
\text { area } \\
\left(\mathbf{m i}^{2}\right)\end{array}$ & $\begin{array}{c}\text { Drainage } \\
\text { density } \\
\left(\mathrm{mi} / \mathrm{mi}^{2}\right)\end{array}$ & $\begin{array}{l}\text { Area of } \\
\text { stratified- } \\
\text { drift } \\
\text { deposits } \\
(\%)\end{array}$ & $\begin{array}{l}\text { Mean } \\
\text { basin } \\
\text { slope } \\
(\%)\end{array}$ & $\begin{array}{l}\text { Date } \\
\text { status of } \\
\text { stream } \\
\text { site was } \\
\text { observed }\end{array}$ & $\begin{array}{l}\text { Observed } \\
\text { status } \\
\text { of stream } \\
\text { site }\end{array}$ & $\begin{array}{l}\text { USGS topo- } \\
\text { graphic } \\
\text { map desig- } \\
\text { nation of } \\
\text { status of } \\
\text { stream site }\end{array}$ & $\begin{array}{l}\text { Probability } \\
\text { of stream } \\
\text { flowing } \\
\text { perennially } \\
\text { at stream } \\
\text { site; } \\
(\%)\end{array}$ \\
\hline \multicolumn{12}{|c|}{ Pembroke } \\
\hline PE-08 & McFarland Brook, Washington Street & 420409 & 704639 & 0.22 & 5.31 & 100.00 & 0.94 & $7-29-99$ & $\mathrm{P}$ & $\mathrm{P}$ & 43 \\
\hline PE-09 & $\begin{array}{l}\text { Unnamed Tributary to McFarland Brook, } \\
\text { Washington Street }\end{array}$ & 420416 & 704644 & .08 & 1.37 & 33.20 & .98 & $7-29-99$ & I & $\mathrm{P}$ & 41 \\
\hline PE-10 & Unnamed Tributary to Swamp Brook, Elm Street & 420429 & 704926 & .19 & 1.98 & 95.16 & 2.08 & $7-29-99$ & I & I & 66 \\
\hline PE-12 & Herring Brook, Barker Street & 420430 & 704804 & 6.14 & 4.15 & 96.64 & .99 & $7-29-99$ & $\mathrm{P}$ & $\mathrm{P}$ & 98 \\
\hline PE-13 & Little Pudding Brook, Barker Street & 420438 & 704757 & .91 & 1.77 & 34.26 & .52 & $7-29-99$ & $\mathrm{P}$ & $\mathrm{P}$ & 77 \\
\hline PE-17 & $\begin{array}{l}\text { Unnamed Tributary to Swamp Brook, } \\
\text { Lowell Road }\end{array}$ & 420453 & 704929 & .12 & .93 & 33.53 & .66 & $7-29-99$ & $\mathrm{P}$ & I & 48 \\
\hline PE-19 & Pudding Brook, Spring Street & 420510 & 704525 & 1.39 & 2.26 & 61.42 & 1.50 & $7-29-99$ & $\mathrm{P}$ & $\mathrm{P}$ & 88 \\
\hline PE-20 & Robinson Creek, Water Street & 420557 & 704715 & 1.12 & 1.25 & 56.87 & 1.02 & $7-29-99$ & $\mathrm{P}$ & $\mathrm{P}$ & 87 \\
\hline PE-23 & McFarland Brook, Congress Street & 420358 & 704643 & .19 & 4.84 & 100.00 & .72 & $7-29-99$ & I & $\mathrm{P}$ & 43 \\
\hline \multicolumn{12}{|c|}{ Rockland } \\
\hline RD-01 & $\begin{array}{l}\text { Unnamed Tributary to French Stream, } \\
\text { Summer Street }\end{array}$ & 420643 & 705333 & 0.52 & 2.33 & 100.00 & 0.54 & $8-04-99$ & $P$ & $P$ & 75 \\
\hline RD-02 & $\begin{array}{l}\text { Unnamed Tributary to French Stream, } \\
\text { Beech Street }\end{array}$ & 420524 & 705359 & .17 & 1.42 & 2.68 & 1.44 & 8-04-99 & I & $\mathrm{P}$ & 40 \\
\hline RD-03 & $\begin{array}{l}\text { Unnamed Tributary to French Stream, } \\
\text { Summer Street }\end{array}$ & 420635 & 705417 & .18 & 3.34 & 56.45 & .47 & 8-04-99 & I & I & 42 \\
\hline RD-04 & French Stream, Summer Street & 420633 & 705433 & 5.07 & 2.42 & 48.79 & .52 & 8-04-99 & $\mathrm{P}$ & $\mathrm{P}$ & 97 \\
\hline RD-06 & $\begin{array}{l}\text { Unnamed Tributary to French Stream, } \\
\text { Spring Street }\end{array}$ & 420643 & 705444 & .40 & 2.14 & 68.11 & .09 & 8-04-99 & $\mathrm{P}$ & I & 65 \\
\hline RD-07 & French Stream, West Water Street & 420717 & 705525 & 2.95 & 2.43 & 47.65 & .56 & 8-04-99 & $\mathrm{P}$ & $\mathrm{P}$ & 94 \\
\hline RD-09 & French Stream, Spruce Street & 420811 & 705603 & .39 & 2.80 & 4.96 & .07 & 8-03-99 & $\mathrm{P}$ & $\mathrm{P}$ & 41 \\
\hline RD-10 & $\begin{array}{l}\text { Unnamed Tributary to Studleys Pond, } \\
\text { North Avenue }\end{array}$ & 420752 & 705532 & .07 & 4.65 & .00 & 9.95 & $8-31-99$ & I & I & 12 \\
\hline RD-11 & $\begin{array}{l}\text { Unnamed Tributary to Studleys Pond, } \\
\text { Reed Street }\end{array}$ & 420742 & 705522 & .57 & 3.79 & .36 & .48 & $8-04-99$ & $\mathrm{P}$ & $\mathrm{P}$ & 40 \\
\hline RD-19 & Cushing Brook, Webster Street & 420805 & 705426 & .50 & 3.43 & 88.67 & .20 & 8-03-99 & $\mathrm{P}$ & $\mathrm{P}$ & 65 \\
\hline
\end{tabular}


Table 5. Description, basin characteristics, and perennial- or intermittent-status determination for field-visited stream sites by town in the South Coastal Basin, southeastern Massachusetts used in development of the logistic regression equation for estimating the probability of a stream flowing perennially in Massachusetts - Continued

\begin{tabular}{|c|c|c|c|c|c|c|c|c|c|c|c|}
\hline $\begin{array}{l}\text { Station } \\
\text { No. }\end{array}$ & Stream-site name and location & $\begin{array}{l}\text { Latitude } \\
\circ, 11\end{array}$ & $\underset{\substack{\text { Longitude } \\
0,11}}{ }$ & $\begin{array}{c}\text { Drainage } \\
\text { area } \\
\left(\mathrm{mi}^{2}\right)\end{array}$ & $\begin{array}{c}\text { Drainage } \\
\text { density } \\
\left(\mathrm{mi} / \mathrm{mi}^{2}\right)\end{array}$ & $\begin{array}{l}\text { Area of } \\
\text { stratified- } \\
\text { drift } \\
\text { deposits } \\
(\%)\end{array}$ & $\begin{array}{c}\text { Mean } \\
\text { basin } \\
\text { slope } \\
(\%)\end{array}$ & $\begin{array}{c}\text { Date } \\
\text { status of } \\
\text { stream } \\
\text { site was } \\
\text { observed }\end{array}$ & $\begin{array}{l}\text { Observed } \\
\text { status } \\
\text { of stream } \\
\text { site }\end{array}$ & $\begin{array}{l}\text { USGS topo- } \\
\text { graphic } \\
\text { map desig- } \\
\text { nation of } \\
\text { status of } \\
\text { stream site }\end{array}$ & $\begin{array}{l}\text { Probability } \\
\text { of stream } \\
\text { flowing } \\
\text { perennially } \\
\text { at stream } \\
\text { site; } \\
(\%)\end{array}$ \\
\hline \multicolumn{12}{|c|}{ Rockland-Continued } \\
\hline RD-20 & Cushing Brook, Liberty Street & 420754 & 705418 & 0.57 & 3.48 & 85.34 & 0.41 & $8-03-99$ & $\mathrm{P}$ & $\mathrm{P}$ & 68 \\
\hline RD-21 & French Stream, North Avenue & 420743 & 705602 & 2.55 & 2.42 & 41.28 & .49 & $8-04-99$ & $\mathrm{P}$ & $P$ & 92 \\
\hline $\mathrm{RD}-23$ & $\begin{array}{l}\text { Unnamed Tributary to Mann Brook, } \\
\text { Hingham Street }\end{array}$ & 420848 & 705411 & .33 & .17 & 73.13 & .04 & 8-03-99 & I & $\mathrm{P}$ & 73 \\
\hline RD-28 & $\begin{array}{l}\text { Unnamed Tributary to French Stream, } \\
\text { Millbrook Street }\end{array}$ & 420552 & 705344 & .55 & 2.25 & 23.40 & 1.21 & $8-04-99$ & I & $\mathrm{P}$ & 65 \\
\hline RD-40 & $\begin{array}{l}\text { Unnamed Tributary to Studleys Pond, } \\
\text { Plain Street }\end{array}$ & 420730 & 705521 & .71 & 3.37 & 10.65 & .60 & $8-04-99$ & $\mathrm{P}$ & I & 57 \\
\hline \multicolumn{12}{|c|}{ Scituate } \\
\hline SE-01 & Satuit Brook, Beaver Dam Road & 421155 & 704420 & 0.80 & 1.92 & 12.85 & 1.03 & $7-16-99$ & $P$ & $\mathrm{P}$ & 71 \\
\hline SE-02 & Satuit Brook, Tilden Road & 421136 & 704404 & 1.26 & 1.72 & 8.22 & .88 & $7-16-99$ & $\mathrm{P}$ & $\mathrm{P}$ & 79 \\
\hline SE-04 & $\begin{array}{l}\text { Unnamed Tributary to Musquashcut Brook, } \\
\text { Hollett Street }\end{array}$ & 421259 & 704616 & .86 & 1.33 & 26.56 & 1.16 & $7-16-99$ & $\mathrm{P}$ & $\mathrm{P}$ & 79 \\
\hline SE-06 & $\begin{array}{l}\text { Unnamed Tributary to Musquashcut Brook, } \\
\text { Captain Pierce Road }\end{array}$ & 421239 & 704605 & .32 & 1.56 & 25.23 & 2.13 & $7-16-99$ & $\mathrm{P}$ & $\mathrm{P}$ & 63 \\
\hline SE-07 & $\begin{array}{l}\text { Unnamed Tributary to Musquashcut Brook, } \\
\text { Branch Way }\end{array}$ & 421225 & 704553 & .19 & .81 & 12.66 & 2.17 & $7-16-99$ & I & I & 55 \\
\hline SE-12 & $\begin{array}{l}\text { Unnamed Tributary to First Herring Brook, } \\
\text { First Parish Road }\end{array}$ & 421148 & 704612 & .34 & 3.35 & 1.27 & .27 & $7-16-99$ & I & $\mathrm{P}$ & 33 \\
\hline SE-14 & First Herring Brook, Maple Street & 421131 & 704638 & 1.79 & 1.44 & 4.46 & 60 & $7-16-99$ & I & $\mathrm{P}$ & 84 \\
\hline SE-16 & $\begin{array}{l}\text { Unnamed Tributary to Bound Brook, } \\
\text { Booth Hill Road }\end{array}$ & 421233 & 704725 & .25 & 2.02 & .00 & .60 & $7-16-99$ & I & I & 34 \\
\hline SE-19 & $\begin{array}{l}\text { Unnamed Tributary to First Herring Brook, } \\
\text { State Route 3A }\end{array}$ & 421156 & 704617 & .33 & 2.92 & .09 & .30 & $7-16-99$ & I & I & 33 \\
\hline SE-21 & First Herring Brook, Grove Street & 421131 & 704647 & 1.75 & 1.43 & 4.56 & .61 & $7-16-99$ & $\mathrm{P}$ & $\mathrm{P}$ & 84 \\
\hline
\end{tabular}


Appendix A 

Appendix A. Summary statistics for selected logistic regression analyses tested for use in development of an equation for estimating the probability of a stream flowing perennially in Massachusetts

[Hosmer and Lemeshow, 1989; Collett, 1991; Helsel and Hirsch, 1992, p. 393-402; Eckhardt and Stackelberg, 1995; SAS Institute Inc., 1995; Squillace and others, 1999. AIC: Akaike Information Criterion. C: rank correlation coefficient of predicted probabilities and observed responses. SCB, South Coastal Basin; ${ }^{1 / 3}$, cube root; ${ }^{1 / 2}$, square root; <, actual value is less than value shown]

\begin{tabular}{|c|c|c|c|c|c|c|c|c|c|c|c|c|}
\hline \multirow{3}{*}{$\begin{array}{c}\text { Equation No. } \\
\text { and explanatory } \\
\text { variables }\end{array}$} & \multicolumn{12}{|c|}{ Analyses } \\
\hline & \multirow[b]{2}{*}{ AIC } & \multirow[b]{2}{*}{ C } & \multirow{2}{*}{$\begin{array}{l}-2 \text { Log } \\
\text { likelihood }\end{array}$} & \multicolumn{3}{|c|}{ Likelihood ratio } & \multicolumn{3}{|c|}{ Score } & \multicolumn{3}{|c|}{$\begin{array}{l}\text { Hosmer and Lemeshow } \\
\text { goodness-of-fit }\end{array}$} \\
\hline & & & & $\begin{array}{l}\text { Chi- } \\
\text { square }\end{array}$ & $\begin{array}{l}\text { Degrees } \\
\text { of } \\
\text { freedom }\end{array}$ & p-value & $\begin{array}{l}\text { Chi- } \\
\text { square }\end{array}$ & $\begin{array}{l}\text { Degrees } \\
\text { of } \\
\text { freedom }\end{array}$ & $p$-value & $\begin{array}{l}\text { Chi- } \\
\text { square }\end{array}$ & $\begin{array}{l}\text { Degrees } \\
\text { of } \\
\text { freedom }\end{array}$ & p-value \\
\hline $\begin{array}{l}\# 1 \\
\text { Intercept } \\
\text { Drainage area } 1 / 3 \\
\text { Location (SCB or remainder of State) } \\
\text { Mean basin slope } \\
\text { Areal percentage of stratified-drift deposits }{ }^{1 / 2} \\
\text { Drainage density }\end{array}$ & 338.604 & 0.790 & 326.604 & 91.7166 & 5 & $<0.0001$ & 77.7929 & 5 & $<0.0001$ & 4.8962 & 8 & 0.7686 \\
\hline $\begin{array}{l}\text { \#2 } \\
\text { Intercept } \\
\text { Drainage area }{ }^{1 / 3} \\
\text { Location (SCB or remainder of State) } \\
\text { Mean basin slope } \\
\text { Areal percentage of stratified-drift deposits }{ }^{1 / 2}\end{array}$ & 342.121 & .786 & 332.121 & 86.1994 & 4 & $<.0001$ & 72.0429 & 4 & $<.0001$ & 8.2218 & 8 & .4121 \\
\hline $\begin{array}{l}\text { \#3 } \\
\text { Intercept } \\
\text { Drainage area }{ }^{1 / 3} \\
\text { Location (SCB or remainder of State) } \\
\text { Mean basin slope }\end{array}$ & 345.513 & .774 & 337.513 & 80.8074 & 3 & $<.0001$ & 68.7859 & 3 & $<.0001$ & 12.0893 & 8 & .1473 \\
\hline $\begin{array}{l}\text { \#4 Intercept } \\
\text { Drainage area }{ }^{1 / 3} \\
\text { Location (SCB or remainder of State) }\end{array}$ & 351.900 & .759 & 345.900 & 72.4206 & 2 & $<.0001$ & 62.9280 & 2 & $<.0001$ & 6.6225 & 8 & .5778 \\
\hline $\begin{array}{l}\# 5 \\
\text { Intercept } \\
\text { Drainage area }\end{array}$ & 399.379 & .641 & 395.379 & 22.9409 & 1 & $<.0001$ & 21.7610 & 1 & $<.0001$ & 7.2108 & 8 & .5141 \\
\hline
\end{tabular}

